\title{
BOILER MATERIALS FOR Ultrasupercritical Coal Power Plants
}

\author{
U.S. DOE NO.: DE-FG26-01NT41175 \\ OCDO NO.: D-00-20
}

\section{Second Quarterly Report January 1 - March 31, 2004}

Prepared by

R. Viswanathan

K. Coleman

J. Shingledecker

J. Sarver

G. Stanko

W. Mohn

M. Borden

S. Goodstine

I. Perrin

Submitted by

R. Viswanathan

K. Coleman

April 23, 2004

\section{Participating Organizations}

Alstom Power, Inc. 2000 Day Hill Road Windsor, CT 06095

McDermott Technology, Inc./

Babcock \& Wilcox Company 1562 Beeson St.

Alliance, $\mathrm{OH} 44601$
Riley Power Inc.

5 Neponset Street

Worcester, MA 01615

Electric Power Research Institute (EPRI)

3412 Hillview Avenue

Palo Alto, CA 94303
Foster Wheeler Development Corp. 12 Peach Tree Hill Road Livingston, NJ 07039

The Energy Industries of Ohio, Inc. Park Center One 6100 Oak Tree Boulevard Independence, OH 44131

Oak Ridge National Labs 1, Bethel Valley Road Oak Ridge, TN 37831 


\section{U.S. Department of Energy Disclaimer}

This report was prepared as an account of work sponsored by an agency of the United States Government. Neither the United States Government nor any agency thereof, nor any of their employees, makes any warranty, express or implied, or assumes any legal liability or responsibility for the accuracy, completeness, or usefulness of any information, apparatus, product, or process disclosed, or represents that its use would not infringe privately owned rights. Reference herein to any specific commercial product, process, or service by trade name, trademark, manufacturer, or otherwise does not necessarily constitute or imply its endorsement, recommendation, or favoring by the United States Government or any agency thereof. The views and opinions of authors expressed herein do not necessarily state or reflect those of the United States Government or any agency thereof.

\section{Project Consortium Legal Notice/Disclaimer}

This report was prepared by the Energy Industries of Ohio in consortium with the Electric Power Research Institute, Inc. (EPRI); Alstom Power, Inc; Riley Power Inc.; Babcock \& Wilcox/McDermott Technology, Inc.; and Foster Wheeler Development Corporation pursuant to a Grant partially funded by the U.S. Department of Energy (DOE) under Instrument Number DE-FG26-01NT41175 and the Ohio Coal Development Office/Ohio Air Quality Development Authority (OCDO/OAQDA) under Grant Agreement Number CDO/D-00-20. NO WARRANTY OR REPRESENTATION, EXPRESS OR IMPLIED, IS MADE WITH RESPECT TO THE ACCURACY, COMPLETENESS, AND/OR USEFULNESS OF INFORMATION CONTAINED IN THIS REPORT. FURTHER, NO WARRANTY OR REPRESENTATION, EXPRESS OR IMPLIED, IS MADE THAT THE USE OF ANY INFORMATION, APPARATUS, METHOD, OR PROCESS DISCLOSED IN THIS REPORT WILL NOT INFRINGE UPON PRIVATELY OWNED RIGHTS. FINALLY, NO LIABILITY IS ASSUMED WITH RESPECT TO THE USE OF, OR FOR DAMAGES RESULTING FROM THE USE OF, ANY INFORMATION, APPARATUS, METHOD OR PROCESS DISCLOSED IN THIS REPORT.

Reference herein to any specific commercial product, process, or service by trade name, trademark, manufacturer, or otherwise, does not necessarily constitute or imply its endorsement, recommendation, or favoring by the Department of Energy and/or the State of Ohio; nor do the views and opinions of authors expressed herein necessarily state or reflect those of said governmental entities. 


\section{Abstract}

The U.S. Department of Energy (DOE) and the Ohio Coal Development Office (OCDO) have recently initiated a project aimed at identifying, evaluating, and qualifying the materials needed for the construction of the critical components of coal-fired boilers capable of operating at much higher efficiencies than current generation of supercritical plants. This increased efficiency is expected to be achieved principally through the use of ultrasupercritical steam conditions (USC). The project goal initially was to assess/develop materials technology that will enable achieving turbine throttle steam conditions of $760^{\circ} \mathrm{C}\left(1400^{\circ} \mathrm{F}\right) / 35 \mathrm{MPa}(5000 \mathrm{psi})$, although this goal for the main steam temperature had to be revised down to $732^{\circ} \mathrm{C}\left(1350^{\circ} \mathrm{F}\right)$, based on a preliminary assessment of material capabilities. The project is intended to build further upon the alloy development and evaluation programs that have been carried out in Europe and Japan. Those programs have identified ferritic steels capable of meeting the strength requirements of USC plants up to approximately $620^{\circ} \mathrm{C}\left(1150^{\circ} \mathrm{F}\right)$ and nickel-based alloys suitable up to $700^{\circ} \mathrm{C}\left(1300^{\circ} \mathrm{F}\right)$. In this project, the maximum temperature capabilities of these and other available high-temperature alloys are being assessed to provide a basis for materials selection and application under a range of conditions prevailing in the boiler. This report provides a quarterly status report for the period of October 1 to December 30, 2003. 


\section{Table of Contents}

Page

ABSTRACT .3

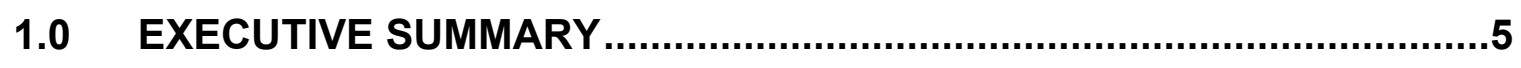

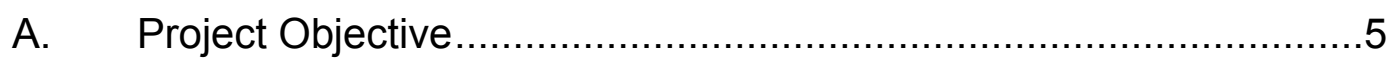

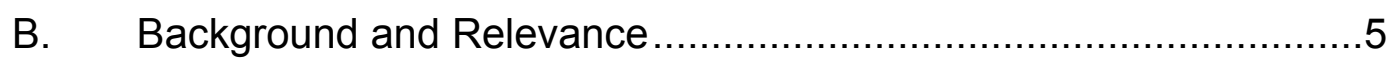

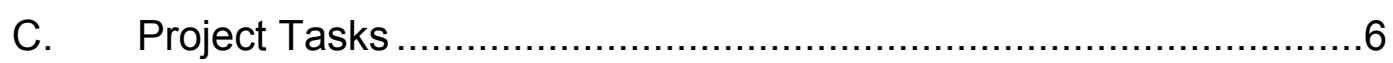

D. Major Accomplishments During the Quarter ................................6

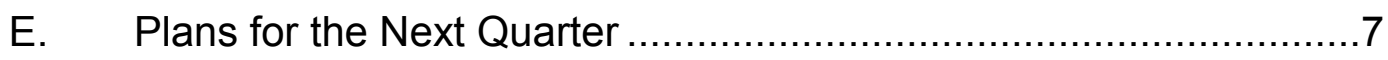

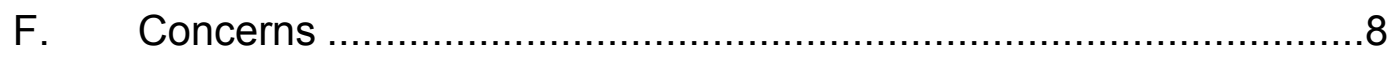

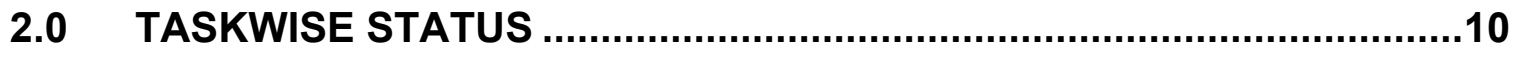

Task 1 Conceptual Design and Economic Analysis..............................10

Task 2 Mechanical Properties of Advanced Alloys ...............................12

Task 3 Steamside Oxidation.......................................................22

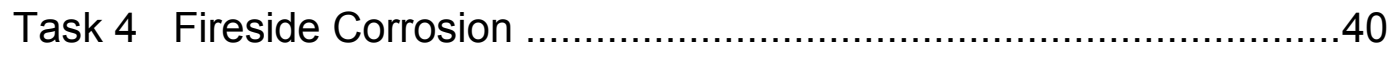

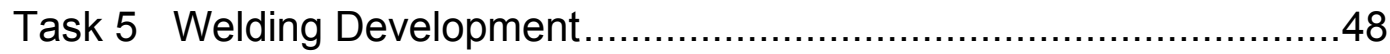

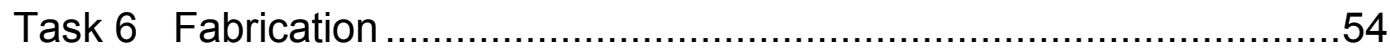

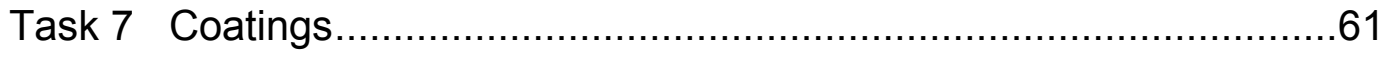

Task 8 Design Methods and Data ...................................................

Task 9 Project Integration and Management .....................................77 


\section{Executive Summary}

\section{A. Project Objective}

The principal objective of this project is to develop materials technology for use in ultrasupercritical (USC) plant boilers capable of operating with $760^{\circ} \mathrm{C}\left(1400^{\circ} \mathrm{F}\right), 35 \mathrm{MPa}$ (5000 psi) steam.

\section{B. Background and Relevance}

In the 21st century, the world faces the critical challenge of providing abundant, cheap electricity to meet the needs of a growing global population while at the same time preserving environmental values. Most studies of this issue conclude that a robust portfolio of generation technologies and fuels should be developed to assure that the United States will have adequate electricity supplies in a variety of possible future scenarios.

The use of coal for electricity generation poses a unique set of challenges. On the one hand, coal is plentiful and available at low cost in much of the world, notably in the U.S., China, and India. Countries with large coal reserves will want to develop them to foster economic growth and energy security. On the other hand, traditional methods of coal combustion emit pollutants and $\mathrm{CO} 2$ at high levels relative to other generation options. Maintaining coal as a generation option in the 21st century will require methods for addressing these environmental issues.

This project has established a government/industry consortium to undertake a five-year effort to evaluate and develop of advanced materials that allow the use of advanced steam cycles in coal-based power plants. These advanced cycles, with steam temperatures up to $760^{\circ} \mathrm{C}$, will increase the efficiency of coal-fired boilers from an average of $35 \%$ efficiency (current domestic fleet) to $47 \%$ (HHV). This efficiency increase will enable coal-fired power plants to generate electricity at competitive rates (irrespective of fuel costs) while reducing $\mathrm{CO}_{2}$ and other fuel-related emissions by as much as $29 \%$.

Success in achieving these objectives will support a number of broader goals. First, from a national prospective, the program will identify advanced materials that will make it possible to maintain a cost-competitive, environmentally acceptable coal-based electric generation option. High sulfur coals will specifically benefit in this respect by having these advanced materials evaluated in high-sulfur coal firing conditions and from the significant reductions in waste generation inherent in the increased operational efficiency. Second, from a national prospective, the results of this program will enable domestic boiler manufacturers to successfully compete in world markets for building high-efficiency coal-fired power plants. 
The project is based on an R\&D plan developed by the Electric Power Research Institute (EPRI) that supplements the recommendations of several DOE workshops on the subject of advanced materials, and DOE's Vision 21. In view of the variety of skills and expertise required for the successful completion of the proposed work, a consortium that includes EPRI and the major domestic boiler manufacturers (Alstom Power, Babcock and Wilcox (a division of McDermott Technologies Inc.), Foster Wheeler and Riley Power Inc.) has been developed.

\section{Project Tasks}

The project objective is expected to be achieved through 9 tasks as listed below:

Task 1. Conceptual Design and Economic Analysis

Task 2. Mechanical Properties of Advanced Alloys

Task 3. Steamside Oxidation Resistance

Task 4. Fireside Corrosion Resistance

Task 5. Welding Development

Task 6. Fabricability

Task $7 . \quad$ Coatings

Task 8. Design Data and Rules

Task 9. Project Integration and Management

\section{Major Accomplishments During the Quarter}

Two reports, one dealing with overall rationale for selection of materials for the project and a second one, dealing with ferritic/martensitic steels have been submitted for review by ORNL. These reports will be issued during the next quarter.

- An executive summary report reviewing all of the progress made to date on the project was issued. Two papers, based on this will be presented at the coal conference in Clearwater, Tampa had in the Baltica conference.

- Results of creep rupture tests have shown that so poor $304 \mathrm{H}$ and alloy 230 meet expectations, while the HR6W is below expectations. The CCA617 alloy performed better than I, the conventional 617 . Results on in coal is 740 show that the alloy is actually stronger than indicated by prior data.

- Techniques for producing TEM foils have been developed for the austenitic and nickel-based materials. Study has begun on the as-received and aged CCA617, Inco 740, Haynes 230 and Super 304H.

- Initial design of a secure website for transferring mechanical property data from Task 2 to the Consortium has been established. A secure password has been applied to the site. Some mechanical property is data has been uploaded. 
- Preparations for laboratory testing for fireside corrosion are well underway. Test materials have been secured and coupon samples have been prepared. Deposit and flue gas compositions for the tests have been identified.

- The first 1000 hour test cycle using tests temperature of $850^{\circ} \mathrm{F}$ for water wall and $1200^{\circ} \mathrm{F}$ for reheater/superheater conditions has been started.

- Matching filler metals were obtained for making joints in HR6W tubing and procedures similar to those using Inco 82 and 617 fillers can now be developed. Two welding process have been quantified for joining tubing.

- A process using out-of-position geometry with matching electrodes has been qualified and plate butt joint samples have been prepared for study for alloy CCA617.

- A series of bends and swaging operations related to the fabrication of HR6W have been completed. Bends have been made with strain levels of $15 \%, 20 \%$, $35 \%$ in this alloy as well as in alloy, Haynes 230.

- Si-Cr scale-up tests were completed during this quarter, and the feasibility of these diffusion coatings has been demonstrated in an intermediate commercial facility using Super $304 \mathrm{H}$ and alloy P92, respectively. Additionally, the SiliconChrome formulation was utilized to coat sections of T23, T91 and alloy HR3C. The compositional profiles for silicon and chromium through the specimens were established.

- The third exposure period at $650^{\circ} \mathrm{C}$ concluded during this quarter. The remaining $650^{\circ} \mathrm{C}$ specimens were removed from the test rack, weighed, descaled and reweighed, and evaluated with SEM/EDX. The results from these analyses were evaluated.

\section{E. Plans for the Next Quarter}

- Creep-rupture tests will continue. A detailed creep-rupture test matrix for the Inconel 740 will be released. Creep-rate tests (stress step-up tests) on thick section material will be started. Creep-rupture tests on the SAVE 12 will begin. Check-out testing will be performed for the thermal shock tests and the thick section structures (feature) testing equipment. Pressurized creep tests on tube bends will begin. Thick section weldments will be started based on the availability of material. The data transfer website will be published.

- Review of literature and benchmarking of procedures will continue. Work will start on the Cyclic Creep subtask by evaluating a flawed header component made of P91 material. 
- Finish literature review and issue a report to summarize issues and methods for weld assessment. Work will begin to collate mechanical property data for weld metal and HAZ regions.

- Completion of the first $800^{\circ} \mathrm{C}$ exposure in steam.

- 1000 hour cycle tests at $850^{\circ} \mathrm{F}$ for waterwall samples and $1200^{\circ} \mathrm{F}$ for reheater/superheater samples for fireside corrosion will be completed.

- Start analyzing coupons from first 1000 hour cycle.

- Start second 1000 hour test cycle at higher temperatures.

- Purchase equipment and materials for fabrication of fireside corrosion probes will be purchased.

- Commence fabrication of probes and retraction mechanism (if funding becomes available).

- Continue efforts to procure matching filler metals for the SAVE12 and Super $304 \mathrm{H}$ materials.

- Begin welding efforts on tubes machined from SAVE12 pipe.

- Qualify HR6W tube butt weld processes using matching filler metal.

- Continue trying to obtain information on gas metal arc welding of Super $304 \mathrm{H}$.

- Fabricate CCA617 tube test specimens using gas tungsten arc process.

- Continue to study problems with shielded metal arc welding of CCA617 thick plates.

- Begin fabrication of super 304H/CCA617 and Super 304H/T91 dissimilar metal weld joints.

- Continue fabrication trials with the HR6W and SAVE12.

- Assess the recrystallization response of strained HR6W and SAVE12 materials based on data generated at Foster Wheeler.

- Continue production of diffusion-coated tubing samples for Task 4.

\section{F. Concerns}

- Due to decrease in the FY 2004 funding level for Task 2, the test plan will have to undergo additional modifications, without change in scope, under Task 2. 
- Due to inadequate funding steamside testing will be terminated after the first $800^{\circ} \mathrm{C}$ exposure is completed, under Task 3.

- Due to inability to come to a legal agreement with Dairyland Power Co., Riley Power has decided to eliminate steam loop testing from their workscope. With available funds, it may be possible to carry out air-cooled probe testing at only one utility site, under Task 4.

- The base material sourcing difficulties and long delivery times have in some cases delayed the start of welding activities by 9 to 12 months.

- The unexpectedly high cost of the nickel base alloys will cause the material budgets to be exceeded and might result in program cost overruns and/or reductions in program scope.

- Submerged arc welding, a high deposition rate process favored by boilermakers for thick sections, does not appear feasible for al nickel-based materials, based on trials with Haynes 230 and Inconel 743, under Task 5.

- Other funding issues need to be resolved before further development on the Haynes 230 and Inconel 740 alloys can continue.

- Some B\&W Task 6 workscope activities may have to be deferred until FY 2005 to adjust to the current funding rate in the project.

- B\&W has indicated that their work on Coatings (Task 7) will be halted pending release of additional funding.

- B\&W supplied externally gladdened test samples may not be available for Task 4 air-cooled, field probe testing in time, under Task 7.

- A much more firm commitment to Task 8 by the various participants is needed.

- Timely, availability of material data in electronic format is a concern. 


\section{$2.0 \quad$ Taskwise Status}

\section{Task 1 \\ Conceptual Design and Economic Analysis (Task lead EPRI)}

The objective of Task 1 is to specify the temperature/pressure distribution for $760^{\circ} \mathrm{C} / 35$ $\mathrm{MPa}\left(1400^{\circ} \mathrm{F} / 5000 \mathrm{psi}\right)$ steam inlet conditions so that the data needs and the range of test parameters can be identified and the economics of material selection established.

\section{Task 1A: Alstom Approach (Alstom Power Co.)}

\section{Objectives}

The primary objectives of this subtask are:

- Develop a conceptual boiler design for a high efficiency ultra supercritical cycle designed for $1400^{\circ} \mathrm{F}$ steam temperature.

- Identify tubing and piping materials needed for high temperature surface construction.

- Estimate gas and steam temperature profiles so that appropriate mechanical, corrosion and manufacturing tests of materials could be designed and conducted to prove suitability of the selected alloys.

\section{Progress for the Task}

A final report has been completed and distributed.

\section{Task 1B: Babcock Approach}

\section{Objective}

The objectives of this subtask are the same as in Subtask 1A.

\section{Progress for the Quarter}

A final report has been completed and distributed.

\section{Task 1C: Economic Analysis}

\section{Objective}

The objective of this task is to determine relative economics of the USC plant. 


\section{Progress for the Task}

A final report has been completed and distributed.

\section{Concerns}

None 


\section{Task 2 \\ Mechanical Properties of Advanced Alloys (ORNL)}

The objective of Task 2 is to produce the mechanical properties database needed to design a boiler to operate at the steam conditions within the scope of the project.

\section{Task 2A: Assessment of the Alloy Performance Requirements}

\section{Objectives}

The primary objectives of this subtask are:

- Focus on performance needed for boiler service in the temperature range of $649^{\circ} \mathrm{C}$ $\left(1200^{\circ} \mathrm{F}\right)$ to $871^{\circ} \mathrm{C}\left(1600^{\circ} \mathrm{F}\right)$

- Produce reports that justify the materials selected for the pressure retention components of the USC boiler

\section{Progress for the Task}

The first part of the assessment report provides an overview identifying the materials selected by the consortium and gives an indication of the scope of the mechanical testing work to meet the project needs. The second part deals with $9-12 \%$ chromium steels. Drafts of Part I and II were completed and issued in January to the consortium for review and publication. The third part, dealing with austenitic iron-bearing alloys, was completed and is undergoing internal review at ORNL. The fourth part, on nickel base alloys, is still being written.

A paper, entitled "Mechanical Properties and Analysis of Ultrasupercritical Steam Boiler Materials," for the Proceedings of the $29^{\text {th }}$ International Technical Conference on Coal Utilization \& Fuel Systems (Clearwater Conference) was approved for publication by the Task leaders and project sponsors. A paper and poster abstract were submitted for the 2004 ASM Materials Solution Conference (October 18-21, 2004: Columbus, OH). Two abstracts were submitted for the EPRI Materials Confrence (October 26-28, 2004: Hilton Head, SC).

\section{Task 2B: Detailed Test Plan}

\section{Progress for the Quarter}

The detailed mechanical properties test plan is intended to provide guidance on the scope of the mechanical testing for each material to support the resolution of issues related to the tasks undertaken in the project. Categories include mechanical characterization; data production for the development of code cases; effects of fabrication variables; weldment performance; fatigue and thermal-fatigue behavior; and 
the like. Progress and/or problems associated with the welding (Task 5) and fabrication (Task 6) tasks will determine testing specifics. Thus, to some measure the test plan continues to evolve. The testing plans for the thick-section materials, SAVE 12, CCA617, alloy 230, and Inconel 740 are still under development. In-depth discussions with Task 8 members at the March $31^{\text {st }}-$ April $1^{\text {st }}$ steering committee meeting helped to prioritize the plans for these materials.

The six alloys, chemical compositions in Table 1 below, of most interest to the project are: SAVE12, Super 304H, HR6W, Haynes 230, CCA617, and INCONEL 740. The characterization testing plans have been completed for four of the six alloys (Super 304H tubing, HR6W tubing, alloy 230 tubing, and CCA617 tubing). The creep-rupture database for Super $304 \mathrm{H}$ stainless steel and alloy 230 was judged to be adequate, since both materials are code alloys. A test plan for INCONEL 740 tubing and plate is being designed. Priority has been given to producing a database for the INCONEL 740 tubing. These data will provide the main body creep/creep-rupture data needed to produce a code case on the material.

\begin{tabular}{|c|c|c|c|c|c|c|c|c|c|c|c|c|c|c|c|}
\hline \multirow[b]{2}{*}{ Alloy } & \multirow[b]{2}{*}{$\mathrm{Fe}$} & \multirow[b]{2}{*}{$\mathrm{Cr}$} & \multirow[b]{2}{*}{$\mathrm{Ni}$} & \multirow[b]{2}{*}{$\mathrm{Mn}$} & \multicolumn{7}{|c|}{ Nominal Compositions in $\mathrm{W} t \%$} & \multirow[b]{2}{*}{$\mathrm{Si}$} & \multirow[b]{2}{*}{$\mathrm{N}$} & \multirow[b]{2}{*}{$\mathrm{Cu}$} & \multirow[b]{2}{*}{ Other } \\
\hline & & & & & Mo & $\mathrm{Ti}$ & $\mathrm{Nb}$ & W & $\mathrm{V}$ & $\mathrm{C}$ & $\mathrm{B}$ & & & & \\
\hline SAVE $12^{*}$ & bal & 11.0 & & 0.2 & & & & 3.00 & 0.20 & 0.10 & & 0.3 & 0.04 & & $\begin{array}{l}3.0 \mathrm{Co} \\
0.07 \mathrm{Ta} \\
0.04 \mathrm{Nd}\end{array}$ \\
\hline Super $304 \mathrm{H}^{\star}$ & bal & 18.0 & 90 & 0.8 & 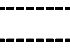 & & 0.40 & & & 0.10 & & 0.2 & 0.10 & 3.00 & \\
\hline $\mathrm{HR} 6 \mathrm{~W}^{*}$ & bail & 230 & 43.0 & 12 & & 0.08 & 0.18 & 60 & & 0.080 & 003 & 04 & & & \\
\hline Haynes $230^{*}$ & 3.0 & 22.0 & bal & 0.5 & 2.0 & & & 14.00 & & 0.10 & 0.02 & 0.4 & & & $\begin{array}{c}5.0 \mathrm{Co} \\
0.3 \mathrm{Al} \\
0.02 \mathrm{La}\end{array}$ \\
\hline CCA617 & 0.6 & 21.7 & bal & 0.03 & 8.6 & 0.40 & & & & 0.05 & 0.002 & 0.1 & 0.01 & 0.01 & $\begin{array}{r}11.25 \mathrm{Co} \\
125 \mathrm{Al}\end{array}$ \\
\hline INCONEL 740 & 2 & 24.0 & bal & 0.3 & 0.5 & 2.0 & 2.0 & & & 0.07 & 0.002 & 0.5 & & & $\begin{array}{r}19.8 \mathrm{Co} \\
0.8 \mathrm{Al} \\
0.015 \mathrm{Zr}\end{array}$ \\
\hline
\end{tabular}

\section{Concerns}

Due to a decrease in the FY2004 funding level for the ORNL task, the test plan will have to undergo additional modifications. At this time it is not anticipated that the scope of the work will change. However, the level of effort (i.e. the number of tests) will be reduced or delayed in certain areas. Specifically, the placing of a subcontract for additional creep-rupture and fatigue work has been delayed from first quarter FY04 to third quarter FY04 to minimize the FY04 cost burden.

The apparent need to overage the thick section INCONEL 740 material for welding will have an impact on the creep strength of the material. The test plan will have to accommodate the different thermal treatments for 740 to determine the processing/properties relationships and provide recommendations to other tasks. 


\section{Task 2C: Long Term Creep Strength}

\section{Objectives}

The primary objectives of this subtask are:

- Identify the general characteristics of the creep behavior and damage accumulation in the candidate alloys

- Verify the creep-strength of code-approved alloys

- Assess the creep-strength non code-approved alloys; and provide creep/creeprupture data for a code case if deemed appropriate by consortium members

- Provide accurate creep data (i.e. creep-curves) for boiler design on the candidate materials

\section{Progress for the Task}

The status for the four of the five alloys currently in testing is provided in the tables below. In each table, comparison of the rupture lives may be made with the expected life based on prior data. The initial results indicate that the strength of the Super $304 \mathrm{H}$ and alloy 230 are meeting expectations, while the HR6W is below expectations. A set of tests on the HR6W has been struck from the test matrix in light of this behavior. The CCA617 alloy is exceeding expectations in the lower temperature regime $\left(650^{\circ} \mathrm{C}\right.$ to $700^{\circ} \mathrm{C}$ ), based on performance equivalent to alloy 617 . Additional short-term tests have been added to the CCA617 test matrix. All of the planned Super $304 \mathrm{H}$ creep-rupture tests are in progress.

The INCONEL 740 tubing was received at ORNL in the nominally solution-annealed condition $\left(1120^{\circ} \mathrm{C}\right.$ anneal). Hardness variations were observed around the circumference of the tube by Foster Wheeler and confirmed by tensile tests at Special Metals. This is most likely due to aging upon cooling. It was the recommendation of ORNL to solution anneal alloy 740 at $1175^{\circ} \mathrm{C}$ or higher for good creep strength.

Therefore, some of the INCONEL 740 tubing has been re-solution annealed at $1190^{\circ} \mathrm{C}$ at ORNL and test specimens are have been prepared from both tubes. Standard creeprupture specimens and notched bar specimens have been prepared from three inch thick INCONEL 740 plate. All specimens were heat treated, in argon, at $800^{\circ} \mathrm{C}$ for 16 hours. Creep-rupture testing on the tube material has begun. As stated before, the alloy 740 plate may need to be overaged to overcome welding difficulties with the material in the solution-annealed and standard aged conditions. Therefore, the test plan for the thick-section 740 will be adjusted accordingly. 


\begin{tabular}{|c|c|c|c|c|c|c|}
\hline \multicolumn{6}{|c|}{ Creep-Rupture Testing of Super $\mathbf{3 0 4} \mathrm{H}$ (Case Code 2328) } \\
\hline Spec \# & Test \# & $\begin{array}{c}\text { Stress } \\
(\mathbf{M P a})\end{array}$ & $\begin{array}{c}\text { Temp. } \\
\left({ }^{\circ} \mathbf{C}\right)\end{array}$ & $\begin{array}{c}\text { Estimated } \\
\text { Life }\end{array}$ & Date Started & $\begin{array}{c}\text { Life } \\
\text { (hrs) }\end{array}$ \\
\hline SM-01 & 30298 & 240 & $600^{\circ} \mathrm{C}$ & $10000 \mathrm{Hrs}$ & $6 / 11 / 2003$ & \\
\hline SM-02 & 30299 & 280 & $600^{\circ} \mathrm{C}$ & $1000 \mathrm{Hrs}$ & $6 / 11 / 2003$ & \\
\hline SM-03 & 30383 & 340 & $600^{\circ} \mathrm{C}$ & $100 \mathrm{Hrs}$ & $12 / 1 / 2003$ & 864.6 \\
\hline SM-04 & 30293 & 120 & $650^{\circ} \mathrm{C}$ & $10000 \mathrm{Hrs}$ & $6 / 3 / 2003$ & \\
\hline SM-05 & 30292 & 210 & $650^{\circ} \mathrm{C}$ & $1000 \mathrm{Hrs}$ & $6 / 3 / 2003$ & 2240 \\
\hline SM-06 & 30372 & 260 & $650^{\circ} \mathrm{C}$ & $100 \mathrm{Hrs}$ & $10 / 21 / 2003$ & 412 \\
\hline SM-07 & 30377 & 110 & $700^{\circ} \mathrm{C}$ & $10000 \mathrm{Hrs}$ & $11 / 24 / 2003$ & \\
\hline SM-08 & 30294 & 160 & $700^{\circ} \mathrm{C}$ & $1000 \mathrm{Hrs}$ & $6 / 3 / 2003$ & 1011.5 \\
\hline SM-09 & 30384 & 210 & $700^{\circ} \mathrm{C}$ & $100 \mathrm{Hrs}$ & $12 / 2 / 2003$ & 106.2 \\
\hline
\end{tabular}

\begin{tabular}{|l|c|c|c|c|c|c|}
\hline Creep-Rupture Testing of HR-6W (Heat \#DZC1309) \\
\hline Spec \# & Test \# & $\begin{array}{c}\text { Stress } \\
\text { (MPa) }\end{array}$ & $\begin{array}{c}\text { Temp. } \\
\left({ }^{\circ} \mathbf{C}\right)\end{array}$ & $\begin{array}{c}\text { Estimated } \\
\text { Life }\end{array}$ & Date Started & $\begin{array}{c}\text { Life } \\
\text { (hrs) }\end{array}$ \\
\hline HR-6W-01 & 30282 & 200 & 650 & 1000 & $5 / 21 / 2003$ & 921.1 \\
\hline HR-6W-02 & 30315 & 175 & 650 & 6000 & $7 / 2 / 2003$ & 2194.2 \\
\hline HR-6W-03 & 30330 & 150 & 650 & 20000 & $7 / 31 / 2003$ & 5167.1 \\
\hline & & 200 & 675 & 500 & & \\
\hline & & 170 & 675 & 1000 & & \\
\hline & & 150 & 675 & 6000 & & \\
\hline HR-6W-08 & 30426 & 100 & 700 & 15000 & $3 / 15 / 2004$ & \\
\hline HR-6W-09 & 30317 & 150 & 700 & 1000 & $7 / 9 / 2003$ & 451.3 \\
\hline HR-6W-10 & 30325 & 120 & 700 & 10000 & $7 / 22 / 2003$ & 2056.7 \\
\hline HR-6W-12 & 30368 & 100 & 725 & 10000 & $10 / 14 / 2003$ & 2663.2 \\
\hline HR-6W-13 & 30283 & 150 & 725 & 500 & $5 / 21 / 2003$ & 187.5 \\
\hline & & 120 & 725 & 5000 & $6 / 2 / 2003$ & 723.8 \\
\hline HR-6W-15 & 30405 & 120 & 750 & 500 & $2 / 2 / 2004$ & 202.5 \\
\hline HR-6W-16 & 30425 & 100 & 750 & 5000 & $3 / 15 / 2004$ & \\
\hline HR-6W-04 & 30424 & 85 & 750 & 20000 & $3 / 15 / 2004$ & \\
\hline HR-6W-05 & 30396 & 100 & 775 & 600 & $12 / 29 / 2003$ & 225 \\
\hline HR-6W-06 & 30401 & 85 & 775 & 5000 & $1 / 14 / 2004$ & 713.6 \\
\hline HR-6W-07 & 30395 & 100 & 800 & 150 & $12 / 29 / 2003$ & 80.24 \\
\hline HR-6W-14 & 30427 & 85 & 800 & 1000 & $3 / 15 / 2004$ & 251.8 \\
\hline
\end{tabular}




\begin{tabular}{|c|c|c|c|c|c|c|}
\hline \multicolumn{7}{|c|}{ Creep-Rupture Testing of Haynes 230} \\
\hline Spec \# & Test \# & $\begin{array}{c}\text { Stress } \\
\text { (MPa) }\end{array}$ & $\begin{array}{c}\text { Temp. } \\
\left({ }^{\circ} \mathrm{C}\right)\end{array}$ & Expected Life & Date Started & $\begin{array}{l}\text { Life } \\
\text { (hrs) }\end{array}$ \\
\hline H230-01 & 30302 & 350 & 650 & 200 & $6 / 16 / 2003$ & 410.8 \\
\hline H230-02 & 30306 & 300 & 650 & 1000 & $6 / 18 / 2003$ & 1071.4 \\
\hline $\mathrm{H} 230-03$ & & 200 & 650 & 10000 & & \\
\hline H230-04 & & 300 & 700 & 100 & & \\
\hline $\mathrm{H} 230-05$ & 30301 & 200 & 700 & 1500 & $6 / 12 / 2003$ & 1517.1 \\
\hline $\mathrm{H} 230-06$ & & 140 & 700 & 15000 & & \\
\hline $\mathrm{H} 230-07$ & & 200 & 750 & 100 & & \\
\hline H230-08 & 30399 & 140 & 750 & 2000 & $1 / 6 / 2004$ & 1501 \\
\hline H230-09 & 30402 & 100 & 750 & 15000 & $1 / 20 / 2004$ & \\
\hline $\mathrm{H} 230-10$ & 30373 & 140 & 800 & 100 & Test Disco & tinued \\
\hline $\mathrm{H} 230-11$ & 30300 & 100 & 800 & 2000 & $6 / 11 / 2003$ & 2101.2 \\
\hline H230-12 & & 80 & 800 & 20000 & & \\
\hline $\mathrm{H} 230-13$ & 30375 & 140 & 800 & 100 & $11 / 3 / 2003$ & 169.2 \\
\hline
\end{tabular}

\begin{tabular}{|c|c|c|c|c|c|c|}
\hline \multicolumn{6}{|c|}{ Creep-Rupture Testing of CCA617 } \\
\hline Spec \# & Test \# & $\begin{array}{c}\text { Stress } \\
(\mathbf{M p a})\end{array}$ & $\begin{array}{c}\text { Temp. } \\
\left({ }^{\circ} \mathbf{C}\right)\end{array}$ & $\begin{array}{c}\text { Estimated } \\
\text { Life }\end{array}$ & Date Started & $\begin{array}{c}\text { Life } \\
(\mathrm{hrs})\end{array}$ \\
\hline $\mathbf{6 1 7 - 0 1}$ & 30303 & $\mathbf{3 5 0}$ & $\mathbf{6 5 0}$ & 200 & $6 / 16 / 2003$ & \\
\hline $\mathbf{6 1 7 - 0 2}$ & 30305 & $\mathbf{3 0 0}$ & $\mathbf{6 5 0}$ & 1000 & $6 / 18 / 2003$ & \\
\hline $\mathbf{6 1 7 - 0 3}$ & 30357 & $\mathbf{2 0 0}$ & $\mathbf{6 5 0}$ & 10000 & $9 / 16 / 2003$ & \\
\hline $\mathbf{6 1 7 - 0 4}$ & 30337 & $\mathbf{3 0 0}$ & $\mathbf{7 0 0}$ & 100 & $8 / 19 / 2003$ & 2376.8 \\
\hline $\mathbf{6 1 7 - 0 5}$ & 30318 & $\mathbf{2 0 0}$ & $\mathbf{7 0 0}$ & 1500 & $7 / 9 / 2003$ & \\
\hline $\mathbf{6 1 7 - 0 6}$ & & $\mathbf{1 4 0}$ & $\mathbf{7 0 0}$ & 15000 & & \\
\hline $\mathbf{6 1 7 - 0 7}$ & 30363 & $\mathbf{2 0 0}$ & $\mathbf{7 5 0}$ & 100 & $9 / 30 / 2003$ & 1561.8 \\
\hline $\mathbf{6 1 7 - 0 8}$ & 30388 & $\mathbf{1 4 0}$ & $\mathbf{7 5 0}$ & 2000 & $12 / 8 / 2003$ & \\
\hline $\mathbf{6 1 7 - 0 9}$ & & $\mathbf{1 0 0}$ & $\mathbf{7 5 0}$ & 15000 & & \\
\hline $\mathbf{6 1 7 - 1 0}$ & 30331 & $\mathbf{1 4 0}$ & $\mathbf{8 0 0}$ & 100 & $8 / 6 / 2003$ & 329.9 \\
\hline $\mathbf{6 1 7 - 1 1}$ & 30343 & $\mathbf{1 0 0}$ & $\mathbf{8 0 0}$ & 2000 & $9 / 3 / 2003$ & 1831 \\
\hline $\mathbf{6 1 7 - 1 2}$ & & $\mathbf{8 0}$ & $\mathbf{8 0 0}$ & 20000 & & \\
\hline $\mathbf{6 1 7 - 1 3}$ & 30352 & $\mathbf{4 0 0}$ & $\mathbf{6 5 0}$ & 200 & $9 / 10 / 2003$ & 1279.7 \\
\hline $\mathbf{6 1 7 - 1 4}$ & 30387 & $\mathbf{4 0 0}$ & $\mathbf{7 0 0}$ & 100 & $12 / 3 / 2003$ & 301.6 \\
\hline $\mathbf{6 1 7 - 1 5}$ & & $\mathbf{3 0 0}$ & $\mathbf{7 5 0}$ & 100 & & \\
\hline
\end{tabular}

\section{Task 2D: Microstructural Analysis}

\section{Objective}

The primary objectives of this subtask are:

- Identify the microstructural changes that lead to significant changes in the strengthening, weakening, and internal damage characteristics of each material.

- Explore how these changes relate to the exposure conditions of the testing. 


\section{Progress for the Task}

The University of Cincinnati has been tasked with the metallurgical characterization of the USC materials (excluding the SAVE12). Techniques for producing TEM foils have been developed for the austenitic and Ni-based materials. Study has begun on the asreceived and aged CCA617, INCONEL 740, Haynes 230, and Super $304 \mathrm{H}$. A report on the characterization progress, for the time period of August 1, 2002 to July 30, 2003, from the UC was received by ORNL. Currently the UC has all the austenitic and Nibased materials, including some material aged to 3,000 hours. A select number of creep tested specimens will be investigated as the task progresses. It is not anticipated that this part of the characterization will begin until the last quarter of FY04.

The characterization work at the UC includes: microhardness, optical microscopy, scanning electron microscopy (SEM) with elemental analysis by energy dispersive spectroscopy (EDS), and transmission electron microscopy (TEM). Short-term aging on the materials is being used by the UC in addition to the longer-term aged materials from ORNL. Using these techniques, the UC will be able to do both qualitative and quantitative analyses of the different microstructures. For example, Figure 1 shows TEM images of Super $304 \mathrm{H}$ after 3,000 hours of aging at $700^{\circ} \mathrm{C}$. The light particles are ultra-fine (nano-sized) Cu precipitates. Cu-bearing stainless steels have improved creep-strength compared to similar stainless steels without $\mathrm{Cu}$. This is an interesting phenomenon, because $\mathrm{Cu}$ is a soft material with a lattice parameter close to that of austenite. Knowledge of changes in the volume fraction, size, and morphology of these precipitates with time and temperature are important to understanding how $\mathrm{Cu}$ can provide strengthening and/or high-temperature stability to the material..

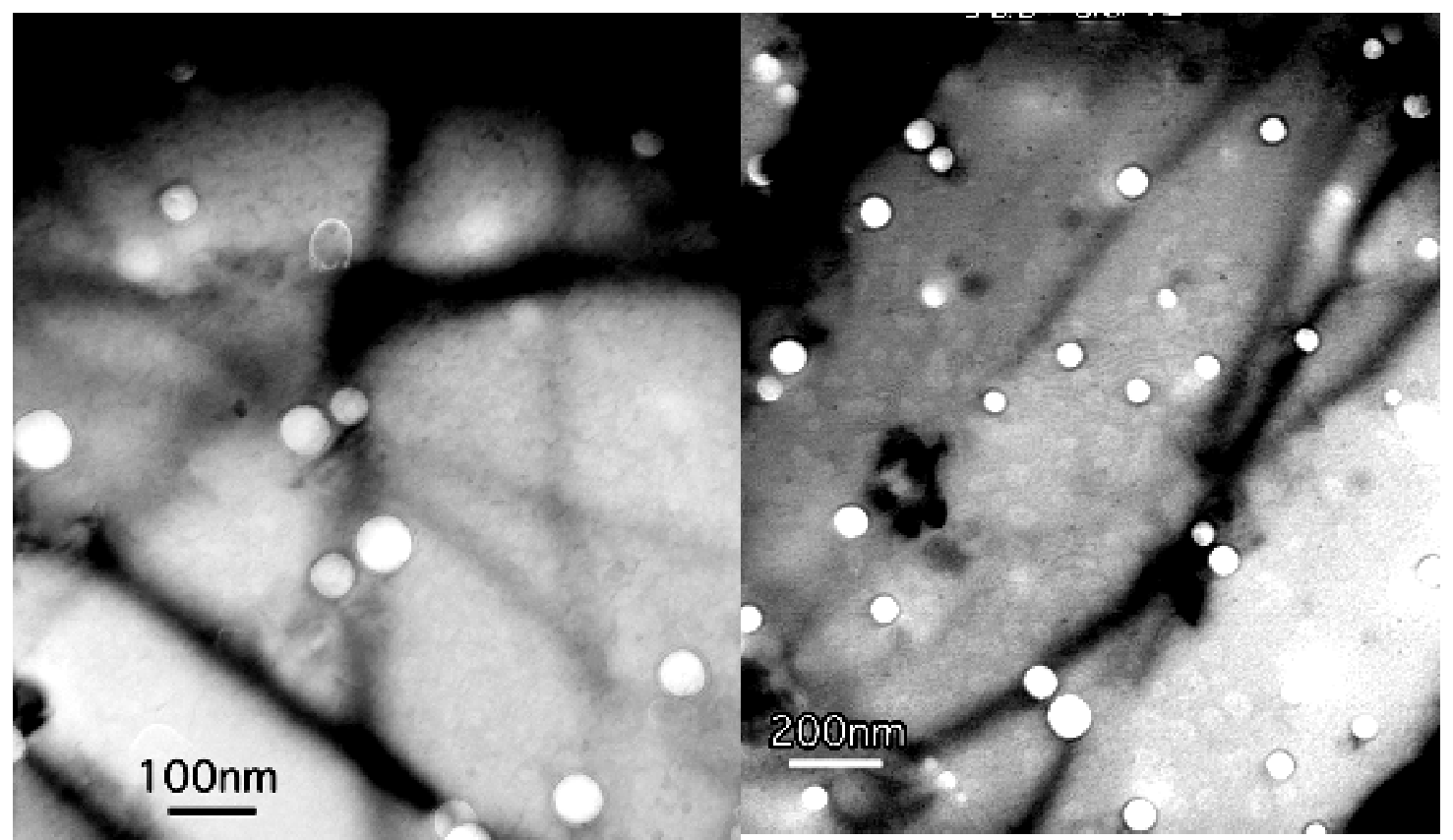

Figure 1 TEM Images of Super $304 \mathrm{H}$, Aged 3,000 hours at $700^{\circ} \mathrm{C}$, showing a dispersion of ultra-fine $\mathrm{Cu}$ (white) precipitates (less than $100 \mathrm{~nm}$ in diameter) 


\section{Task 2E: Assessment of Creep-Fatigue Properties}

\section{Objectives}

The primary objectives of this subtask are:

- Develop a database that will lead to practical, yet conservative methods.

- Address the issue of creep-fatigue in the boiler materials.

\section{Progress for the Task}

Testing of SAVE12 fatigue specimens was delayed due to the reconditioning of safety equipment on the test machine. These modifications have been completed and checkout testing will begin next quarter. Further, continuous cycling fatigue testing will be performed under subcontract to a testing lab.

\section{Task 2F: Modeling of Weld Joints}

\section{Objectives}

The primary objectives of this subtask are:

- Produce the experimental data needed to model dissimilar metal and thick-section weld joints.

\section{Progress for the Task}

To date, only weldments in Haynes 230 tube and thin plate (1/4") have been received. Creep-rupture testing on the Haynes 230 tube cross-weldments is nearing completion. Creep-rupture testing on the plate has started for weld-metal-only, cross-weldments, and parallel weldments (with base metal on either side of the weldment). The progress of these tests is indicated in the tables below. 


\begin{tabular}{|c|c|c|c|c|c|c|}
\hline Creep-Rupture Testing: Haynes 230 (Tube 5) Cross-Weldments \\
\hline Spec \# & Test \# & $\begin{array}{c}\text { Stress } \\
\text { (MPa) }\end{array}$ & $\begin{array}{c}\text { Temp. } \\
\left({ }^{\circ} \mathbf{C}\right)\end{array}$ & $\begin{array}{c}\text { Base Metal } \\
\text { Expected Life }\end{array}$ & Date Started & $\begin{array}{c}\text { Life } \\
\text { (hrs) }\end{array}$ \\
\hline H230-W01 & 30311 & $\mathbf{3 5 0}$ & $\mathbf{6 5 0}$ & 200 & $6 / 26 / 2003$ & 84.9 \\
\hline H230-W02 & 30290 & $\mathbf{3 0 0}$ & $\mathbf{6 5 0}$ & 1000 & $6 / 3 / 2003$ & 825.4 \\
\hline H230-W03 & 30313 & $\mathbf{3 0 0}$ & $\mathbf{7 0 0}$ & 100 & $7 / 1 / 2003$ & 22.7 \\
\hline H230-W04 & 30319 & $\mathbf{2 0 0}$ & $\mathbf{7 0 0}$ & 1500 & $7 / 10 / 2003$ & 207.1 \\
\hline H230-W05 & 30320 & $\mathbf{2 0 0}$ & $\mathbf{7 5 0}$ & 100 & $7 / 14 / 2003$ & 30.7 \\
\hline H230-W06 & 30327 & $\mathbf{1 4 0}$ & $\mathbf{7 5 0}$ & 2000 & $7 / 23 / 2003$ & 170.6 \\
\hline H230-W07 & 30328 & $\mathbf{2 0 0}$ & $\mathbf{6 5 0}$ & 10000 & $7 / 24 / 2003$ & 1550.6 \\
\hline H230-W08 & 30332 & $\mathbf{1 4 0}$ & $\mathbf{7 0 0}$ & 15000 & $8 / 6 / 2003$ & 1472 \\
\hline Creep-Rupture Testing: Haynes 230 (Tube 2) Cross-Weldments \\
\hline H230-W09 & 30361 & $\mathbf{1 0 0}$ & $\mathbf{8 0 0}$ & 2000 & $9 / 23 / 2003$ & 231.6 \\
\hline H230-W10 & 30365 & $\mathbf{8 0}$ & $\mathbf{8 0 0}$ & 20000 & $10 / 1 / 2003$ & 419.2 \\
\hline H230-W11 & 30369 & $\mathbf{6 0}$ & $\mathbf{8 0 0}$ & \multicolumn{4}{|c|}{$10 / 14 / 2003$} & \\
\hline H230-W12 & 30370 & $\mathbf{1 0 0}$ & $\mathbf{7 5 0}$ & 15000 & $10 / 14 / 2003$ & 1117.8 \\
\hline
\end{tabular}

\begin{tabular}{|c|c|c|c|c|c|c|}
\hline \multicolumn{6}{|c|}{ Creep-Rupture Testing: Haynes 230 Weld Metal (Plate 3) } \\
\hline Spec \# & Test \# & $\begin{array}{c}\text { Stress } \\
(\mathbf{M P a})\end{array}$ & $\begin{array}{c}\text { Temp. } \\
(\circ \mathbf{C})\end{array}$ & $\begin{array}{c}\text { Estimated Life } \\
(\mathrm{hrs})\end{array}$ & Date Started & $\begin{array}{c}\text { Life } \\
(\mathrm{hrs})\end{array}$ \\
\hline W3-01 & 30403 & $\mathbf{2 0 0}$ & $\mathbf{6 5 0}$ & 1500 & $1 / 22 / 2004$ & \\
\hline W3-02 & & $\mathbf{1 4 0}$ & $\mathbf{7 0 0}$ & 1500 & & \\
\hline W3-03 & & $\mathbf{1 0 0}$ & $\mathbf{7 5 0}$ & 1500 & & \\
\hline W3-04* & & $\mathbf{1 0 0}$ & $\mathbf{7 5 0}$ & 1500 & & \\
\hline W3-05 & & $\mathbf{8 0}$ & $\mathbf{8 0 0}$ & 1500 & & \\
\hline
\end{tabular}

\begin{tabular}{|c|c|c|c|c|c|c|}
\hline \multicolumn{6}{|c|}{ Creep-Ruture Testing:Haynes 230 Cross Weld (Plate 2) } \\
\hline Spec \# & Test \# & $\begin{array}{c}\text { Stress } \\
(\mathbf{M P a})\end{array}$ & $\begin{array}{c}\text { Temp. } \\
\left({ }^{\circ} \mathbf{C}\right)\end{array}$ & $\begin{array}{c}\text { Estimated Life } \\
(\mathrm{hrs})\end{array}$ & Date Started & $\begin{array}{c}\text { Life } \\
(\mathrm{hrs})\end{array}$ \\
\hline CW-01 & 30418 & $\mathbf{2 0 0}$ & $\mathbf{6 5 0}$ & 1500 & $3 / 2 / 2004$ & \\
\hline CW-02 & & $\mathbf{1 4 0}$ & $\mathbf{7 0 0}$ & 1500 & & \\
\hline CW-03 & & $\mathbf{1 0 0}$ & $\mathbf{7 5 0}$ & 1500 & & \\
\hline CW-04 & & $\mathbf{8 0}$ & $\mathbf{8 0 0}$ & 1500 & & \\
\hline
\end{tabular}

\begin{tabular}{|c|c|c|c|c|c|c|}
\hline \multicolumn{7}{|c|}{ Creep-Rupture Testing:Haynes 230 Parallel Weld (Plate 2) } \\
\hline Spec \# & Test \# & $\begin{array}{c}\text { Stress } \\
(\mathbf{M P a})\end{array}$ & $\begin{array}{c}\text { Temp. } \\
\left({ }^{\circ} \mathbf{C}\right)\end{array}$ & $\begin{array}{c}\text { Estimated Life } \\
(\mathrm{hrs})\end{array}$ & Date Started & $\begin{array}{c}\text { Life } \\
(\mathrm{hrs})\end{array}$ \\
\hline PW-01 & 30419 & $\mathbf{2 0 0}$ & $\mathbf{6 5 0}$ & 2000 & $3 / 2 / 2004$ & \\
\hline PW-02 & & $\mathbf{1 4 0}$ & $\mathbf{7 0 0}$ & 2000 & & \\
\hline PW-03 & & $\mathbf{1 0 0}$ & $\mathbf{7 5 0}$ & 2000 & & \\
\hline PW-04 & & $\mathbf{8 0}$ & $\mathbf{8 0 0}$ & 2000 & & \\
\hline
\end{tabular}

At the March-April USC steering committee meeting, ORNL raised the issue of dissimilar metal welds. Due to the large number of dissimilar metal welds possible in the boiler, ORNL asked if the key transitions had been identified. In general, the thinking of the consortium was that all thick section welds will be made with the same material (in other words; no austenitic materials will go directly into a Ni-based header) 
and, therefore, the thick section evaluations would be based strictly on weldments. For the tubing, the key transitions will be 304H/T91, 304H/CCA617, and CCA617/INCONEL 740 , with the later two being the most important.

\section{Task 2G: Study of Accelerated Test Methods}

\section{Objectives}

The primary objective of this task is:

- Provide a method to rapidly characterize changes in the strength of candidate materials.

\section{Progress}

The purported high creep strength $9 \mathrm{Cr}$ ferritic Abe Alloy (nano-nitride) was of interest to the consortium. Two thick plates (1" thick) were received from Abe on March $30^{\text {th }}$, 2004. This material will be tested by stress relaxation and compared to standard $9 \mathrm{Cr}-$ $1 \mathrm{Mo}$.

\section{Task 2H: Model Validation}

\section{Objectives}

The primary objective of this task is:

- Produce a database that can be used to confirm or validate design rules that are developed in Task 8.

\section{Progress}

A deeply notched 740 specimen has been machined. Standard ASTM V-groove notched bars of 740 plate have also been machined. Tube bends have been prepared for testing cold work limits. Testing of the tubes will begin next quarter. A thermal shock testing facility was designed for thick wall tubes. Specimens were machined for check-out testing.

\section{Task 2I: Data Transfer Web Site}

\section{Objectives}

The primary objective of this task is:

- Develop and maintain a secure website for transferring mechanical properties data from Task 2 to the consortium. 


\section{Progress}

The initial design of the website is complete. A secure password has been applied to the site. Some mechanical properties data has been uploaded. Early next quarter a letter will be sent to consortium members with the password to access the data.

\section{Concerns}

There has been a decrease in the FY2004 funding level for the ORNL task. At this time it is not anticipated that the scope of the work will change. However, the level of effort (i.e. the number of tests) will be reduced or delayed in certain areas. Specifically, the placing of a subcontract for additional creep-rupture and fatigue work has been delayed from first quarter FY04 to third quarter FY04 to minimize the FY04 cost burden.

\section{Plans for Next Quarter}

Creep-rupture tests will continue. A detailed creep-rupture test matrix for the INCONEL 740 will be released. Creep-rate tests (stress step-up tests) on thick section material will be started. Creep-rupture tests on the SAVE 12 will begin. Check-out testing will be performed for the thermal shock tests and the thick section structures (feature) testing equipment. Pressurized creep tests on tube bends will begin. Thick section weldments will be started based on the availability of material. The data transfer website will be published. 


\section{Task 3 \\ Steamside Oxidation \\ $(\mathrm{B} \& W)$}

\section{Task 3A: Autoclave Testing}

\section{Background}

Steamside oxidation tests will be performed on commercially available and

developmental materials at temperatures between $650^{\circ} \mathrm{C}$ and $900^{\circ} \mathrm{C}\left(1202^{\circ} \mathrm{F}-1652^{\circ} \mathrm{F}\right)$.

\section{Experimental}

The third exposure period at $650^{\circ} \mathrm{C}$ concluded during this quarter. The remaining $650 \mathrm{oC}$ specimens were removed from the test rack, weighed, descaled and re-weighed, and evaluated with SEM/EDX. The results from these analyses were evaluated and are presented below under the following headings: Weight Change, Descaled Weight Loss, Exfoliation, and Metallographic Evaluations.

\section{Weight Change}

- Measured Weight Change

- The average measured weight change for the materials under test after the three exposure periods are presented in Table 1. In general, the materials that did not experienced exfoliation displayed weight gain between the 2,000 hour exposure and the 4,000 hour exposure, after displaying essentially no weight gain between the 1,000 hour exposure and the 2,000 hour exposure. The weight change of the specimens that experienced exfoliation was erratic. The ferritic materials exhibited greater weight gain than the austenitic materials. 


\section{TABLE 1}

\section{$650^{\circ} \mathrm{C}$ Measured Weight Change Results}

\begin{tabular}{|c|c|c|c|c|}
\hline \multirow{2}{*}{ Specimen \# } & \multirow{2}{*}{$\% \mathrm{Cr}$} & \multicolumn{3}{|c|}{ Measured Weight Change $\left(\mathrm{mg} / \mathrm{cm}^{2}\right)$} \\
\hline & & 1000 hours & 2000 hours & 4000 hours \\
\hline $\mathrm{T} 23$ & 2.09 & $26.810^{* *}$ & $29.745^{\star *}$ & $26.601^{* *}$ \\
\hline P91 & 8.29 & $3.184^{* *}$ & $-0.890^{* *}$ & $4.923^{* *}$ \\
\hline $\mathrm{P} 92$ & 8.93 & $7.462^{\star *}$ & $4.864^{* *}$ & $9.387^{* *}$ \\
\hline AbeNN & 8.95 & $19.378^{* *}$ & ---- & $6.372^{* *}$ \\
\hline Abe & 9.16 & 0.358 & 0.326 & 0.436 \\
\hline AbePO & 9.16 & 0.173 & ---- & $0.037^{* *}$ \\
\hline SAVE12 & 9.25 & 4.596 & 5.837 & 7.800 \\
\hline VM12 & 11.37 & 0.174 & ---- & 0.349 \\
\hline $304 \mathrm{H}$ & 18.83 & 0.249 & 0.247 & 0.317 \\
\hline $\mathrm{S} 304 \mathrm{H}$ & 19.1 & 0.113 & 0.112 & 0.222 \\
\hline $800 \mathrm{HT}$ & 19.49 & 0.281 & 0.272 & 0.470 \\
\hline $\mathrm{N} 263$ & 20.02 & 0.146 & 0.123 & 0.280 \\
\hline CCA617 & 21.73 & 0.124 & 0.116 & 0.207 \\
\hline SAVE25 & 21.85 & 0.147 & 0.153 & 0.245 \\
\hline 230 & 22.42 & 0.219 & 0.199 & 0.304 \\
\hline HR6W & 23.44 & 0.241 & 0.232 & 0.319 \\
\hline 740 & 24.31 & 0.138 & 0.096 & 0.421 \\
\hline HR120 & 25.94 & 0.208 & 0.161 & 0.285 \\
\hline CrP92 & * & -0.018 & 0.249 & 0.235 \\
\hline SiCrP92 & * & 0.007 & 0.308 & 0.728 \\
\hline AlCrP92 & * & 0.735 & 1.623 & 2.276 \\
\hline ElessNiP92 & * & $1.453^{\star *}$ & 2.050 & $11.363^{\star *}$ \\
\hline CBP92 & * & $3.979^{* *}$ & $-10.286^{\star \star}$ & $1.260^{* *}$ \\
\hline DCr602 & * & ---- & ----- & 0.291 \\
\hline DCrHR120 & * & ----- & ---- & 0.262 \\
\hline DCr253 & * & ----- & ----- & 0.139 \\
\hline DCr333 & * & ----- & ----- & 0.131 \\
\hline DCr617 & * & - & ---- & 0.273 \\
\hline DCr740 & * & ---- & ---- & 0.297 \\
\hline DCr353 & * & ----- & ---- & 0.146 \\
\hline DCr230 & * & ----- & ----- & 0.338 \\
\hline
\end{tabular}

* - The values for these specimens reflect the wt. gain or wt. loss only from the coating (wt. gain and wt. loss from the exposed base metal in the holes was subtracted from the total wt. gain or wt. loss)

** - Exfoliation observed

- $\quad$ Exposure time was 3111 hours 
- Calculated Weight Change

Weight change values calculated from weight loss data are displayed in Table 2. These calculations were made using the following assumptions: 1) for ferritic materials, all weight loss was from $\mathrm{Fe}$ atoms, 2) for austenitic materials, all weight loss was from metal with a molecular weight of $55.5 \mathrm{~g} / \mathrm{mole}, 3$ ) for ferritic materials, the weight gain is due to incorporation of oxygen in the formation of $\mathrm{Fe}_{3} \mathrm{O}_{4}$, and 4) for austenitic materials, the weight gain is due to incorporation of oxygen in the formation of a metal oxide with the composition of $\mathrm{M}_{2} \mathrm{O}_{3}$.

For the ferritic materials, calculated weight gain generally decreased as the chromium content increased. The ferritic alloys which exhibited the best performance at $650^{\circ} \mathrm{C}$ were the Abe alloy and VM12. The results for the Abe alloy show some discrepancy in that the specimen exposed for 2,000 hours had a higher calculated weight gain than the specimen exposed for 4,000 hours.

The calculated weight gain values for austenitic materials were less than for ferritic materials and did not directly correlate with the chromium content. Austenitic alloys CCA617 and 740 displayed the best performance at $650^{\circ} \mathrm{C}$.

TABLE 2

Weight Change Calculated from Weight Loss

\begin{tabular}{|c|c|c|c|c|}
\hline \multirow[t]{2}{*}{ Specimen \# } & \multirow[t]{2}{*}{$\% \mathrm{Cr}$} & \multicolumn{3}{|c|}{ Weight Change Calculated from Weight Loss $\left(\mathrm{mg} / \mathrm{cm}^{2}\right.$} \\
\hline & & 1000 hours & 2000 hours & 4000 hours \\
\hline T23 & 2.09 & 42.654 & 49.068 & 56.980 \\
\hline P91 & 8.29 & 14.161 & 17.865 & 24.735 \\
\hline $\mathrm{P} 92$ & 8.93 & 5.425 & 7.349 & 11.675 \\
\hline AbeNN & 8.95 & 22.264 & ----- & 19.549 \\
\hline Abe & 9.16 & 0.188 & 0.461 & 0.396 \\
\hline AbePO & 9.16 & 0.219 & ----- & 2.441 \\
\hline SAVE12 & 9.25 & 5.707 & 6.770 & 8.794 \\
\hline VM12 & 11.37 & 0.279 & ----- & 0.434 \\
\hline $304 \mathrm{H}$ & 18.83 & 0.253 & 0.297 & 0.334 \\
\hline $\mathrm{S} 304 \mathrm{H}$ & 19.1 & 0.192 & 0.205 & 0.305 \\
\hline $800 \mathrm{HT}$ & 19.49 & 0.264 & 0.265 & 0.292 \\
\hline N263 & 20.02 & 0.086 & 0.129 & 0.186 \\
\hline CCA617 & 21.73 & 0.099 & 0.108 & 0.114 \\
\hline SAVE25 & 21.85 & 0.191 & 0.174 & 0.215 \\
\hline 230 & 22.42 & 0.253 & 0.278 & 0.279 \\
\hline HR6W & 23.44 & 0.208 & 0.232 & 0.260 \\
\hline 740 & 24.31 & 0.087 & 0.112 & 0.121 \\
\hline HR120 & 25.94 & 0.204 & 0.228 & 0.275 \\
\hline
\end{tabular}

- Exposure time was 3111 hours 
- Calculation of $k_{p}$

- Based on the calculated weight change data after 1000, 2000, and 4000 hours (1000 and 3000 hours for Abe PO, Abe NN and VM12), the oxidation rate constant, $\mathrm{k}_{\mathrm{p}}$, was calculated for each material assuming parabolic kinetics (weight change is proportional to the square root of time). The results are displayed in Table 3 along with $k_{p}$ values generated by $O R N L$ at $700^{\circ} \mathrm{C}$, and predicted $\mathrm{k}$ values for the parabolic oxidation of ferritic materials from Table III of CORROSION 2002 Paper 020377 by Wright and Pint $\left(k=A e^{-Q / R T}\right)$.

TABLE 3

\begin{tabular}{|c|c|c|c|c|c|c|c|c|}
\hline \multirow[b]{2}{*}{ Material } & \multirow[b]{2}{*}{$\% \mathrm{Cr}$} & \multicolumn{3}{|c|}{$\begin{array}{c}\text { From BRWC Calculated Weight } \\
\text { Change }\end{array}$} & \multicolumn{2}{|c|}{$\begin{array}{l}\text { ORNL Results at } \\
700^{\circ} \mathrm{C}^{*}\end{array}$} & \multicolumn{2}{|c|}{$\begin{array}{c}\text { Predicted } k_{p} \text { for } \\
\text { Ferritic Materials } \\
\left(g^{2} \mathrm{~cm}^{-4} \mathbf{s}^{-1}\right)\end{array}$} \\
\hline & & $\begin{array}{c}\text { Test } \\
\text { Temperature } \\
\text { (C) } \\
\end{array}$ & $\left(g^{2} \mathrm{~cm}^{-4} s^{-1}\right)$ & $\mathbf{R}^{2}$ & $\left(g^{2} \mathrm{~cm}^{-4} s^{-1}\right)$ & $\mathbf{R}^{2}$ & $\begin{array}{c}\text { At } \\
\text { BWRC } \\
\text { Test } \\
\text { Temp } \\
\end{array}$ & $700^{\circ} \mathrm{C}$ \\
\hline T23 & 2.09 & 633 & $2.96 \mathrm{E}-10$ & 0.886 & ---- & - ---- & $5.94 \mathrm{E}-10$ & $5.09 \mathrm{E}-9$ \\
\hline P91 & 8.29 & 633 & $4.57 \mathrm{E}-11$ & 0.985 & $\begin{array}{l}2.42 \mathrm{E}-13- \\
57.6 \mathrm{E}-13\end{array}$ & $\begin{array}{l}0.988- \\
0.971\end{array}$ & $5.43 \mathrm{E}-11$ & 2.06E-10 \\
\hline P92 & 8.93 & 640 & $8.92 \mathrm{E}-12$ & 0.995 & $7.50 \mathrm{E}-11$ & 0.995 & 6.30E-11 & $2.06 \mathrm{E}-10$ \\
\hline Abe NN & 8.95 & 650 & $5.29 \mathrm{E}-11$ & 0.683 & ----- & ----- & $7.76 \mathrm{E}-11$ & 2.06E-10 \\
\hline Abe & 9.16 & 650 & $1.54 \mathrm{E}-14$ & 0.807 & ---- & $-\cdots$ & $7.76 \mathrm{E}-11$ & $2.06 \mathrm{E}-10$ \\
\hline Abe PO & 9.16 & 640 & $3.35 \mathrm{E}-13$ & 0.716 & $\begin{array}{ll}--- \\
--1\end{array}$ & ----- & $6.30 \mathrm{E}-11$ & $2.06 \mathrm{E}-10$ \\
\hline SAVE12 & 9.25 & 646 & $6.25 \mathrm{E}-12$ & 0.954 & ---- & ----- & $7.15 \mathrm{E}-11$ & $2.06 \mathrm{E}-10$ \\
\hline VM12 & 11.37 & 656 & $1.80 \mathrm{E}-14$ & 0.992 & ---- & ---- & 8.78E-11 & $2.06 \mathrm{E}-10$ \\
\hline $304 \mathrm{H}$ & 18.83 & 653 & $1.04 \mathrm{E}-14$ & 0.875 & ----- & ----- & & \\
\hline Super $304 \mathrm{H}$ & 19.1 & 655 & $7.80 \mathrm{E}-15$ & 0.958 & ---- & ----- & & \\
\hline $800 \mathrm{HT}$ & 19.49 & 658 & $8.61 \mathrm{E}-15$ & 0.761 & ---- & ---- & & \\
\hline Nimonic 263 & 20.02 & 640 & $2.38 \mathrm{E}-15$ & 1.000 & $\begin{array}{l}---- \\
\end{array}$ & ----- & & \\
\hline CCA617 & 21.73 & 646 & $1.33 \mathrm{E}-15$ & 0.783 & ----- & ----- & & \\
\hline SAVE25 & 21.85 & 660 & $4.33 \mathrm{E}-15$ & 0.777 & $2.20 E-15$ & 0.953 & & \\
\hline Alloy 230 & 22.42 & 653 & $8.35 E-15$ & 0.748 & ----- & ----- & & \\
\hline HR6W & 23.44 & 661 & $6.43 E-15$ & 0.846 & ----- & ----- & & \\
\hline Alloy 740 & 24.31 & 655 & $1.37 \mathrm{E}-15$ & 0.891 & $2.70 \mathrm{E}-15$ & 0.964 & & \\
\hline HR120 & 25.94 & 650 & $6.71 \mathrm{E}-15$ & 0.894 & $2.60 \mathrm{E}-15$ & 0.993 & & \\
\hline
\end{tabular}

* - ORNL data included in e-mail from lan Wright to Jeff Sarver, December 2, 2003

** - k calculation based on CORROSION 2002 Paper 020377 Table III (Wright and Pint)

For most materials, the correlation factors following the 4,000 hour exposure are less than those from the 2,000 hour data. This trend suggests that the oxidation kinetics have not remained constant throughout the exposures. This will be discussed further in the Descaled Weight Loss section of this report. 
Even though the $\mathrm{k}_{\mathrm{p}}$ values calculated from the BWRC $650^{\circ} \mathrm{C}$ data after 4,000 hours is slightly different than the $k_{p}$ values calculated after 2,000 hours, the trends reported in the previous Quarterly Report are still observed: 1) BWRC $k_{p}$ values for baseline ferritics (T23 and P91) are in good agreement with the predicted rate constants but do not agree well with the ORNL values generated at $700^{\circ} ; 2$ ) the rate constants for the new ferritic materials are lower than predicted (showing that the new ferritic materials have better oxidation resistance than the baseline ferritic materials) and 3) $k_{p}$ values generated by BWRC at $650^{\circ} \mathrm{C}$ and by ORNL at $700^{\circ} \mathrm{C}$ for austenitic materials are similar.

\section{Descaled Weight Loss}

- Measured Weight Loss

- Following the exposures, one specimen from each material was descaled using alkaline permanganate, hot diammonium citrate and, when necessary, hot inhibited hydrochloric acid. The descaled weights are reported in Table 4. Of the ferritic materials tested, the Abe alloy exhibited the best descaled weight loss performance, followed by VM12. The descaled weight loss exhibited by the Abe PO alloy after 1,000 hours was only slightly higher than that exhibited by the Abe alloy, but after 3,000 hours of exposure, the Abe PO alloy exhibited much greater weight loss than the Abe alloy did after 4,000 hours of exposure.

- All of the austenitic materials displayed descaled weight loss values that were less than the ferritic materials. Even the best performing ferritic material (Abe alloy) had a descaled weight loss that was $47 \%$ higher than the worst performing austenitic alloy $(304 \mathrm{H})$ after 4,000 hours. The best performing austenitic alloys (CCA617 and Alloy 740) exhibited descaled weight loss values that were nearly three times less than the descaled weight loss exhibited by $304 \mathrm{H}$. 
TABLE 4

Descaled Weight Loss

\begin{tabular}{|c|c|c|c|c|}
\hline \multirow[t]{2}{*}{ Specimen \# } & \multirow[t]{2}{*}{$\% \mathrm{Cr}$} & \multicolumn{3}{|c|}{ Descaled Weight Loss $\left(\mathrm{mg} / \mathrm{cm}^{2}\right)$} \\
\hline & & 1000 hours & 2000 hours & 4000 hours \\
\hline T23 & 2.09 & 111.659 & 128.451 & 149.163 \\
\hline P91 & 8.29 & 37.071 & 46.767 & 64.752 \\
\hline P92 & 8.93 & 14.202 & 19.239 & 30.562 \\
\hline AbeNN & 8.95 & 58.282 & ---- & 51.176 \\
\hline Abe & 9.16 & 0.492 & 1.208 & 1.038 \\
\hline AbePO & 9.16 & 0.572 & ----- & 6.389 \\
\hline SAVE12 & 9.25 & 14.939 & 17.724 & 23.020 \\
\hline VM12 & 11.37 & 0.730 & ----- & 1.136 \\
\hline $304 \mathrm{H}$ & 18.83 & 0.586 & 0.688 & 0.772 \\
\hline $\mathrm{S} 304 \mathrm{H}$ & 19.1 & 0.444 & 0.474 & 0.706 \\
\hline $800 \mathrm{HT}$ & 19.49 & 0.612 & 0.614 & 0.676 \\
\hline N263 & 20.02 & 0.200 & 0.299 & 0.430 \\
\hline CCA617 & 21.73 & 0.230 & 0.251 & 0.264 \\
\hline SAVE25 & 21.85 & 0.442 & 0.403 & 0.497 \\
\hline 230 & 22.42 & 0.585 & 0.644 & 0.646 \\
\hline HR6W & 23.44 & 0.482 & 0.536 & 0.602 \\
\hline 740 & 24.31 & 0.201 & 0.258 & 0.279 \\
\hline HR120 & 25.94 & 0.473 & 0.529 & 0.636 \\
\hline CrP92 & * & 0.944 & 2.006 & -0.291 \\
\hline SiCrP92 & * & 1.193 & 2.433 & -0.173 \\
\hline AlCrP92 & * & -0.448 & 0.805 & -0.861 \\
\hline ElessNiP92 & * & ----- & 6.527 & 35.977 \\
\hline
\end{tabular}

* - The values for these specimens reflect the wt. gain or wt. loss only from the coating (wt. gain and wt. loss from the exposed base metal in the holes was subtracted from the total wt. gain or wt. loss)

- Exposure time was 3111 hours

- Kinetics

- The descaled weight loss data contained in Table 4 were analyzed to determine whether the materials were exhibiting parabolic or linear oxidation. From the data, it appeared that several materials exhibited a different weight loss vs. time $\left(\right.$ or time ${ }^{1 / 2}$ ) slope after the first exposure period, as demonstrated for HR120 in Figure 1. The slope and $R^{2}$ values for the complete data set and data from $\sim 1,000$ hours until the end of the test are displayed in Table 5. 


\section{HR120}

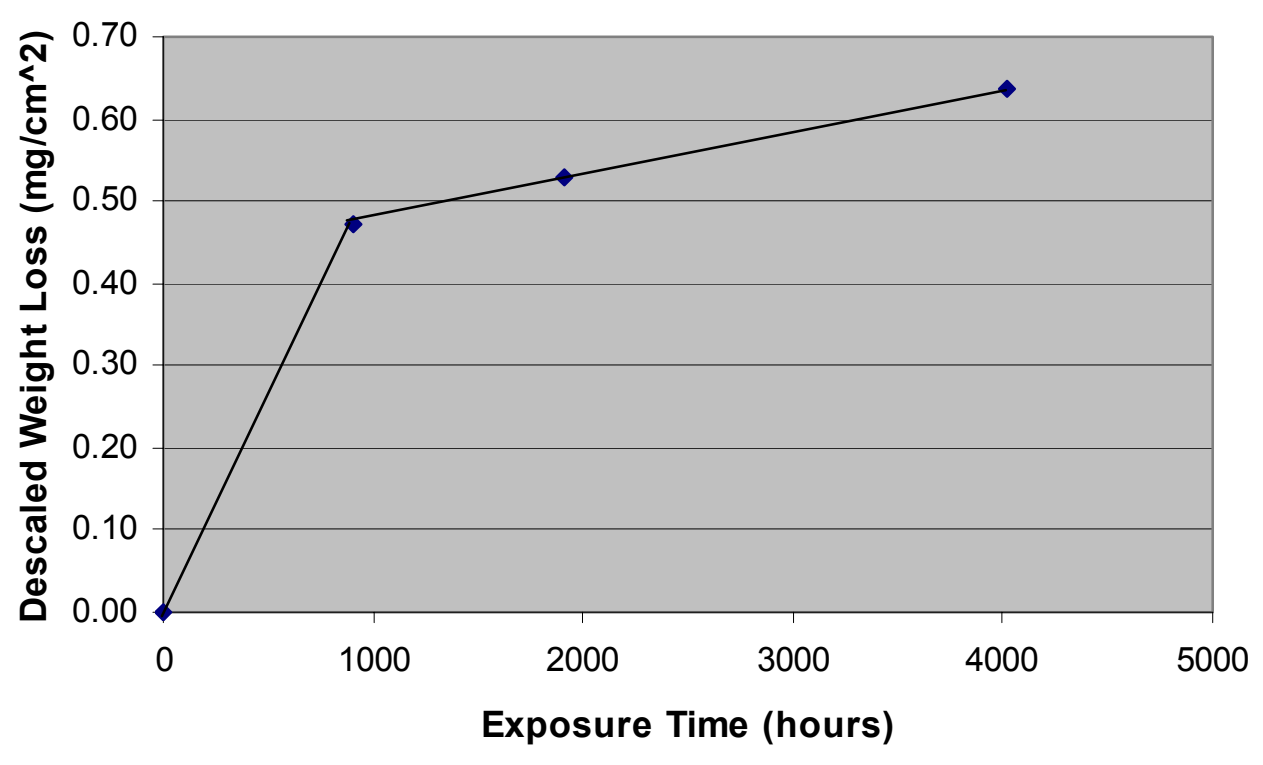

Figure 1. Oxidation Kinetics Slope Change for HR120

The data contained in Table 5 indicate that, for most materials, the kinetics for the first $\sim 1,000$ hours of exposure was different than the kinetics for the remainder of the exposure. The lower values of slope indicate that the oxidation kinetics were lower after the first $\sim 1,000$ hours of exposure. For many of the materials, it is not clear whether the oxidation is following linear or parabolic kinetics, since the $R^{2}$ values for the linear and parabolic data fits are essentially equivalent.

For materials where low $\mathrm{R}^{2}$ values are reported for all conditions (eg., Abe, SAVE25 and AbeNN), the descaled weight loss did not consistently increase with time. Since these analyses were performed on only one specimen per material per time period, the oxidation kinetics for these materials cannot be delineated with certainty.

Using the linear and parabolic slopes calculated from $\sim 1,000$ hours through the end of the test, the calculated weight loss after 100,000 hours assuming linear oxidation kinetics is 3-4 times greater than the weight loss if parabolic kinetics are assumed. For the austenitic alloys, both linear and parabolic kinetics result in 100,000 hour weight losses at $650^{\circ} \mathrm{C}$ of $<10 \mathrm{mg} / \mathrm{cm}^{2}$. However, for the ferritic materials that experienced significant weight loss, knowing whether the oxidation kinetics are linear or parabolic 
becomes important. If these ferritic alloys are to be used at this temperature, longer test exposures at $650^{\circ} \mathrm{C}$ should be conducted to elucidate their oxidation kinetics.

TABLE 5

Oxidation Kinetics from Descaled Weight Loss

\begin{tabular}{|c|c|c|c|c|c|c|c|c|}
\hline \multirow[b]{2}{*}{ Material } & \multicolumn{4}{|c|}{0 - 4015.5 Hours } & \multicolumn{4}{|c|}{ 904.5 - 4015.5 Hours } \\
\hline & $\begin{array}{c}\text { Linear Slope } \\
\left(\times 10^{-3} \mathrm{mg} \mathrm{cm}^{-2} \mathrm{hr}^{-1}\right)\end{array}$ & $\mathbf{R}^{2}$ & $\begin{array}{c}\text { Parabolic Slope } \\
\left(\mathrm{x}^{-3} \mathrm{mg} \mathrm{cm}^{-2} \mathrm{hr}^{-12}\right)\end{array}$ & $\mathbf{R}^{2}$ & $\begin{array}{c}\text { Linear Slope } \\
\left(\times 10^{-3} \mathrm{mg} \mathrm{cm}^{-2} \mathrm{hr}^{-1}\right)\end{array}$ & $\mathbf{R}^{2}$ & $\begin{array}{c}\text { Parabolic Slope } \\
\left(\times 10^{-3} \mathrm{mg} \mathrm{cm}^{-2} \mathrm{hr}^{-1 / 2}\right)\end{array}$ & $\mathbf{R}^{2}$ \\
\hline T23 & 45.9 & .414 & 2697 & .886 & 11.7 & .980 & 1121 & .998 \\
\hline P91 & 18.6 & .716 & 1063 & .985 & 8.85 & .999 & 837 & .995 \\
\hline P92 & 8.37 & .868 & 469 & .995 & 5.28 & 1.00 & 497 & .987 \\
\hline Abe & 0.34 & .501 & 19.5 & .808 & 0.14 & .336 & 14.7 & .430 \\
\hline SAVE12 & 6.79 & .596 & 393 & .954 & 2.59 & .999 & 245 & .994 \\
\hline $304 \mathrm{H}$ & 0.24 & .385 & 14.1 & .874 & 0.06 & .937 & 5.50 & .975 \\
\hline S304H & 0.02 & .665 & 11.5 & .957 & 0.09 & .952 & 8.12 & .903 \\
\hline N263 & 0.12 & .841 & 6.78 & 1.00 & 0.07 & .986 & 6.92 & .999 \\
\hline $800 \mathrm{HT}$ & 0.22 & .177 & 12.9 & .761 & 0.02 & .918 & 2.02 & .857 \\
\hline CCA617 & 0.08 & .205 & 5.07 & .784 & 0.01 & .892 & 1.00 & .945 \\
\hline 230 & 0.21 & .140 & 12.7 & .748 & 0.02 & .586 & 1.7 & .679 \\
\hline SAVE25 & 0.15 & .237 & 9.13 & .776 & 0.02 & .536 & 1.88 & .439 \\
\hline HR6W & 0.19 & .327 & 11.1 & .846 & 0.04 & .979 & 3.58 & .998 \\
\hline HR120 & 0.19 & .436 & 11.4 & .893 & 0.05 & 1.00 & 4.93 & .994 \\
\hline 740 & 0.09 & .419 & 5.13 & .888 & 0.02 & .798 & 2.26 & .870 \\
\hline \multirow[b]{2}{*}{ Material } & \multicolumn{4}{|c|}{$0-3111$ Hours } & \multicolumn{4}{|c|}{$1008-3111$ Hours } \\
\hline & $\begin{array}{c}\text { Linear Slope } \\
\left(\times 10^{-3} \mathrm{mg} \mathrm{cm}^{-2} \mathrm{hr}^{-1}\right)\end{array}$ & $\mathbf{R}^{2}$ & $\begin{array}{c}\text { Parabolic Slope } \\
\left(\times 10^{-3} \mathrm{mg}^{2} \mathrm{~cm}^{-4} \mathrm{hr}^{-1}\right)\end{array}$ & $\mathbf{R}^{2}$ & $\begin{array}{c}\text { Linear Slope } \\
\left(\times 10^{-3} \mathrm{mg} \mathrm{cm}^{-2} \mathrm{hr}^{-1}\right) \\
\end{array}$ & $\mathbf{R}^{2}$ & $\begin{array}{c}\text { Parabolic Slope } \\
\left(\times 10^{-3} \mathrm{mg}^{2} \mathrm{~cm}^{-4} \mathrm{hr}^{-1}\right)\end{array}$ & $\mathbf{R}^{2}$ \\
\hline AbePO & 1.91 & .919 & 90.9 & .716 & 2.77 & 1.00 & 242 & 1.00 \\
\hline AbeNN & 20.4 & .222 & 1142 & .683 & -3.38 & 1.00 & -296 & 1.00 \\
\hline VM12 & 0.40 & .822 & 21.0 & .992 & 0.19 & 1.00 & 16.9 & 1.00 \\
\hline
\end{tabular}

\section{- Effect of Composition}

As was reported in the previous Quarterly Report, the oxidation behavior of the seven ferritic alloys in test correlated very well with specific alloying elements in the alloys. In the previous report, composition was plotted against the parabolic slope after 2,000 hours of exposure. Since the 4,000 hour data did not clearly indicate linear or parabolic kinetics for these materials, the composition was plotted against the 4,000 hour weight loss data (for the AbeNN and VM12 materials, the weight loss measured after 3111 hours was extrapolated to 4015.5 hours).

Figure 2 continues to indicate that the composition correlates well with descaled weight loss data. Through an iterative process, it was found that the descaled weight loss could be described as a function of $0.9[\mathrm{Cr}]+63[\mathrm{C}]+240[\mathrm{~B}]$ with an excellent linear fit, as shown in Figure 2. 


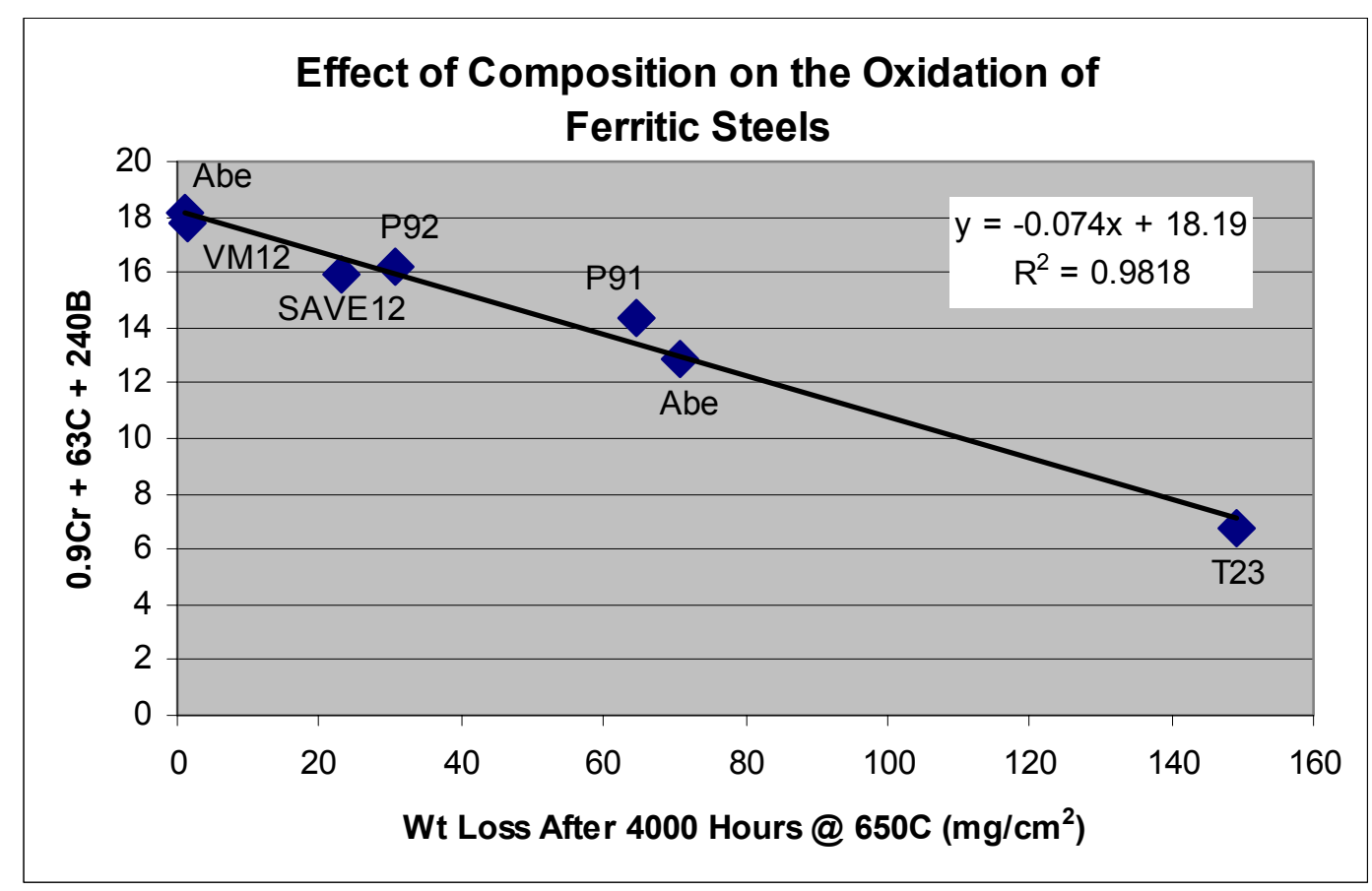

Figure 2. Effect of Composition on the Parabolic Rate Constant for Ferritic Materials Tested at $650^{\circ} \mathrm{C}$

These results suggest that the carbon content and the boron content, along with the chromium content, play a consistent and significant role in determining the steamside oxidation behavior of ferritic materials.

\section{Exfoliation}

The weight of exfoliated oxide from each material was calculated by subtracting the calculated weight change from the measured weight change (Table 2 and Table 1). Since the weight change represents only the weight of the oxygen which has been incorporated into the oxide, this value was converted to $\mathrm{mg}$ of exfoliated oxide per unit area by assuming that the exfoliated oxide from ferritic materials was $\mathrm{Fe}_{3} \mathrm{O}_{4}$, and that the exfoliated oxide from austenitic materials was $\mathrm{M}_{2} \mathrm{O}_{3}$, where $\mathrm{M}$ had a molecular weight of $55.5 \mathrm{~g} / \mathrm{mole}$. The calculated weight of exfoliated oxide per unit area is shown in Table 6. 
TABLE 6

\begin{tabular}{|c|c|c|c|c|}
\hline \multicolumn{5}{|c|}{ USC Task 3 - 650C Test } \\
\hline \multirow{3}{*}{ Material } & \multirow{2}{*}{$\%$ Cr } & \multicolumn{3}{c|}{ Callowing 4000 Hours of Exposure } \\
\cline { 3 - 5 } & & 1000 hours & $\mathbf{2 0 0 0}$ hours & $\mathbf{4 0 0 0}$ hours \\
\hline T23 & 2.09 & 79.918 & 73.421 & 127.727 \\
\hline P91 & 8.29 & 39.615 & 87.566 & 62.456 \\
\hline P92 & 8.93 & -17.800 & 3.966 & 13.254 \\
\hline AbeNN & 8.95 & 12.734 & & $93.868^{*}$ \\
\hline Abe & 9.16 & -0.655 & 0.473 & -0.129 \\
\hline AbePO & 9.16 & 0.296 & & $6.244^{*}$ \\
\hline SAVE12 & 9.25 & 2.926 & 4.164 & 5.287 \\
\hline VM12 & 11.37 & 0.486 & & $0.159^{*}$ \\
\hline $304 H$ & 18.83 & -0.070 & 0.172 & 0.037 \\
\hline S304H & 19.1 & 0.268 & 0.328 & 0.338 \\
\hline $800 H T$ & 19.49 & 0.009 & -0.108 & -0.803 \\
\hline N263 & 20.02 & -0.191 & 0.064 & -0.319 \\
\hline CCA617 & 21.73 & -0.114 & -0.043 & -0.316 \\
\hline SAVE25 & 21.85 & 0.186 & 0.090 & -0.119 \\
\hline 230 & 22.42 & 0.182 & 0.280 & -0.083 \\
\hline HR6W & 23.44 & -0.081 & 0.028 & -0.199 \\
\hline 740 & 24.31 & -0.128 & 0.066 & -0.321 \\
\hline HR120 & 25.94 & -0.057 & 0.238 & -0.078 \\
\hline
\end{tabular}

* - Exposure time was 3111 hours

The results indicate that significant oxide exfoliation occurred on ferritic materials, with the exception of the Abe and VM12 alloys. The austenitic materials have experienced only minor oxide exfoliation after 4,000 hours of exposure at $650^{\circ} \mathrm{C}$, as evidenced by calculated weight of exfoliated metal oxide values that are approximately zero. Calculated weight of exfoliated metal oxide values that are negative are indicative of experimental variations in the measurements. It appears that the possible error in the 4,000 hour values listed in Table 6 is approximately $\pm 1 \mathrm{mg} / \mathrm{cm}^{2}$.

\section{Metallographic Evaluation}

Following the final exposure period, one specimen from each material was submitted for SEM/EDS evaluation. These results are presented in Tables 7 and 8 , along with the oxide thickness results following the previous exposures. Note that the Abe NN, Abe $\mathrm{PO}$ and VM12 specimens listed in Table 7 were added to the test matrix prior to the second 1,000 hour exposure; thus, these specimens were examined after 1,000 and 3,000 hours. 
The SEM/EDS results continue to show some oxide growth on both ferritic and austenitic materials. Disbonding of the outer oxide on P92 and AbeNN was observed at the inner/outer oxide interface, and also within the outer oxide, as shown in Figure 3. Several of the austenitic materials are showing evidence of oxide fingers extending into the matrix. The character of the oxides has changed little during the exposures.

TABLE 7

\begin{tabular}{|c|c|c|c|c|c|c|}
\hline \multirow[b]{2}{*}{ Material } & \multirow[b]{2}{*}{$\% \mathrm{Cr}$} & \multirow{2}{*}{$\begin{array}{l}\text { Oxide Thickness } \\
\text { After } 1,000 \text { Hours } \\
\text { of Exposure } \\
\text { (microns) }\end{array}$} & \multirow{2}{*}{$\begin{array}{l}\text { Oxide Thickness } \\
\text { After 2,000 Hours } \\
\text { of Exposure } \\
\text { (microns) }\end{array}$} & \multirow{2}{*}{$\begin{array}{l}\text { Oxide Thickness } \\
\text { After } 4,000 \text { Hours } \\
\text { of Exposure } \\
\text { (microns) }\end{array}$} & \multicolumn{2}{|c|}{ 4,000 Hour Results } \\
\hline & & & & & $\begin{array}{c}\text { Oxide } \\
\text { Composition }\end{array}$ & Comments \\
\hline T23 & 2.09 & $\begin{array}{l}150 \\
\text { outer }-50 \\
\text { next - } 20 \\
\text { next - } 20 \\
\text { inner - } 60\end{array}$ & $\begin{array}{l}260 \\
\text { outer - } 130 \\
\text { inner - } 130\end{array}$ & $\begin{array}{l}265 \\
\text { outer }-95 \\
\text { inner }-170\end{array}$ & $\begin{array}{l}\text { outer layers - Fe } \\
\text { oxide } \\
\text { inner layers - Fe } \\
\text { oxide enriched in } \\
\mathrm{Cr}\end{array}$ & \\
\hline P91 & 8.29 & $\begin{array}{l}30 \\
\text { outer - } 15 \\
\text { inner - } 15\end{array}$ & $\begin{array}{l}70-90 \\
\text { outer - 30-40 } \\
\text { inner - 40-50 }\end{array}$ & $\begin{array}{l}100 \\
\text { outer }-22 \\
\text { inner }-78\end{array}$ & $\begin{array}{l}\text { outer - Fe oxide } \\
\text { inner - Fe oxide } \\
\text { enriched in } \mathrm{Cr}\end{array}$ & $\begin{array}{l}\text { Highest } \mathrm{Cr} \text { in inner scale is near } \\
\text { inner/outer interface } \\
\text { Mo-rich zone at interface between } \\
\text { inner scale and base metal }\end{array}$ \\
\hline P92 & 8.93 & $\begin{array}{l}5-30 \\
\text { outer - 5-15 } \\
\text { inner - 0-15 }\end{array}$ & $\begin{array}{l}50 \\
\text { outer - } 30 \\
\text { inner - } 20\end{array}$ & $\begin{array}{l}116 \\
\text { outer }-64 \\
\text { inner }-52\end{array}$ & $\begin{array}{l}\text { outer - Fe oxide } \\
\text { with very minor } \mathrm{Cr} \\
\text { inner - Fe oxide } \\
\text { highly enriched in } \\
\mathrm{Cr}\end{array}$ & $\begin{array}{l}\text { In some locations essentially no } \\
\text { oxide was observed } \\
\text { Cr-rich zones in inner oxide are in } \\
\text { layers } \\
\text { Outer oxide disbonding at } \\
\text { inner/outer interface and also } \\
\text { within outer layer }\end{array}$ \\
\hline Abe NN & 8.95 & $\begin{array}{l}130-165 \\
\text { outer - 90 } \\
\text { inner - 40-75 }\end{array}$ & ---- & $\begin{array}{l}3,000 \text { hours } \\
160 \\
\text { outer }-80 \\
\text { inner }-80\end{array}$ & $\begin{array}{l}\text { outer - Fe oxide } \\
\text { with Co } \\
\text { inner - Fe oxide } \\
\text { highly enriched in } \\
\mathrm{Cr}\end{array}$ & $\begin{array}{l}\text { Outer oxide layer defective and } \\
\text { disbonding } \\
\text { Some outer oxide has spalled } \\
\text { from the surface } \\
\text { W-rich precipitates near } \\
\text { inner/outer interface }\end{array}$ \\
\hline Abe & 9.16 & $\begin{array}{l}3 \\
\text { outer }-1.5 \\
\text { inner }-1.5\end{array}$ & $\begin{array}{l}3 \\
\text { outer - } 2 \\
\text { inner - } 1\end{array}$ & $\begin{array}{l}4 \\
\text { outer }-1 \\
\text { inner }-3\end{array}$ & $\begin{array}{l}\text { outer - } \mathrm{Fe} \text { oxide } \\
\text { with some } \mathrm{Cr} \\
\text { inner - } \mathrm{Cr} \text { oxide } \mathrm{w} / \\
\text { some } \mathrm{Fe} \text { and } \mathrm{Mn}\end{array}$ & W-rich precipitates in the matrix \\
\hline Abe PO & 9.16 & 0 & ---- & $\begin{array}{l}3,000 \text { hours } \\
0.5\end{array}$ & $\begin{array}{l}\text { Cr-Fe oxide } \\
\text { observed in some } \\
\text { locations }\end{array}$ & W-rich precipitates in the matrix \\
\hline SAVE12 & 9.25 & $\begin{array}{l}45 \\
\text { outer - } 25 \\
\text { mid - } 1 \\
\text { inner - } 19\end{array}$ & $\begin{array}{l}50 \\
\text { outer - 20-30 } \\
\text { mid - } 1 \\
\text { inner - } 20\end{array}$ & $\begin{array}{l}80 \\
\text { outer }-40 \\
\text { inner }-40\end{array}$ & $\begin{array}{l}\text { outer - Fe oxide } \\
\text { inner - } \mathrm{Cr} / \mathrm{Fe} \text { oxide }\end{array}$ & $\begin{array}{l}\mathrm{Cr} \text { depletion below inner oxide } \\
\text { Nd-rich precipitates in the matrix } \\
\mathrm{Cr} \text {-rich zones in the inner oxide } \\
\text { are in layers }\end{array}$ \\
\hline VM12 & 11.37 & 5 & ----- & $\begin{array}{l}3,000 \text { hours } \\
2 \\
\text { only } 1 \text { layer } \\
\text { observed }\end{array}$ & $\begin{array}{l}\text { Cr oxide with } \mathrm{Fe} \\
\text { and enriched in } \mathrm{Mn}\end{array}$ & $\begin{array}{l}\text { W-rich precipitates observed in } \\
\text { matrix }\end{array}$ \\
\hline
\end{tabular}


TABLE 8

\begin{tabular}{|c|c|c|c|c|c|c|}
\hline \multicolumn{7}{|c|}{ SEM/EDS Evaluation Results - Austenitic Materials } \\
\hline \multirow[b]{2}{*}{ Material } & \multirow[b]{2}{*}{$\% \mathrm{Cr}$} & \multirow{2}{*}{$\begin{array}{c}\text { Oxide } \\
\text { Thickness After } \\
1,000 \text { Hours of } \\
\text { Exposure } \\
\text { (microns) } \\
\end{array}$} & \multirow{2}{*}{$\begin{array}{c}\text { Oxide } \\
\text { Thickness After } \\
2,000 \text { Hours of } \\
\text { Exposure } \\
\text { (microns) } \\
\end{array}$} & \multirow{2}{*}{$\begin{array}{c}\text { Oxide } \\
\text { Thickness After } \\
\text { 4,000 Hours of } \\
\text { Exposure } \\
\text { (microns) } \\
\end{array}$} & \multicolumn{2}{|c|}{ 4,000 Hour Results } \\
\hline & & & & & Oxide Composition & Comments \\
\hline $304 \mathrm{H}$ & 18.83 & $5 \max$ & 3 & 12 & $\begin{array}{l}\text { Mixed } \mathrm{Cr} \text { oxide and } \mathrm{Fe} \\
\text { oxide }\end{array}$ & $\begin{array}{l}\text { Some areas have essentially no } \\
\text { oxide }\end{array}$ \\
\hline $\begin{array}{l}\text { Super } \\
304 \mathrm{H}\end{array}$ & 19.1 & 2 & 1 & 1 & Cr oxide enriched in $\mathrm{Mn}$ & $\begin{array}{l}4 \text { micron wide } \mathrm{Cr} \text { depletion below } \\
\text { oxide } \\
\text { near surface } \mathrm{Nb} \text { particles } \\
\text { observed } \\
\text { oxide was fractured }\end{array}$ \\
\hline $\begin{array}{l}\text { Nimonic } \\
263\end{array}$ & 20.02 & $1 \max$ & 3 & 2 & $\begin{array}{l}\text { Cr oxide enriched in Ti and } \\
\text { Mn }\end{array}$ & $\begin{array}{l}\text { Cr and Ti depleted zone } \\
\text { observed below oxide } \\
\text { short oxide fingers extend into } \\
\text { matrix }\end{array}$ \\
\hline $800 \mathrm{HT}$ & 19.49 & 2 & $\begin{array}{l}3-4 \\
\text { outer - 2-3 } \\
\text { inner - } 1\end{array}$ & 6 & $\begin{array}{l}\mathrm{Cr} \text { oxide enriched in } \mathrm{Ti} \text { and } \\
\mathrm{Mn} \\
\text { Al oxide at oxide/matrix } \\
\text { interface }\end{array}$ & oxide fingers extend into matrix \\
\hline CCA617 & 21.73 & 1 & 1 & 1 & Cr oxide enriched in Al & $\begin{array}{l}\text { oxide fingers extend } \sim 1 \text { micron } \\
\text { into matrix }\end{array}$ \\
\hline $\begin{array}{l}\text { Alloy } \\
230\end{array}$ & 22.42 & 1 & $<1$ & 1 & $\begin{array}{l}\text { Cr oxide enriched in } \mathrm{Mn} \\
\text { and } \mathrm{Al}\end{array}$ & $\begin{array}{l}\text { Very large W-rich globular } \\
\text { precipitates in matrix }\end{array}$ \\
\hline SAVE25 & 21.85 & 1 & 1 & 1 & Cr oxide enriched in $\mathrm{Mn}$ & $\begin{array}{l}4 \text { micron wide } \mathrm{Cr} \text { depletion below } \\
\text { oxide } \\
\mathrm{Nb} \text {-rich precipitates observed in } \\
\text { matrix }\end{array}$ \\
\hline HR6W & 23.44 & $<1$ & 1 & 2 & Cr oxide enriched in Mn & \\
\hline HR120 & 25.94 & 1 & 1 & 2 & Cr oxide enriched in $\mathrm{Mn}$ & $\begin{array}{l}\text { short oxide fingers extend into } \\
\text { matrix }\end{array}$ \\
\hline $\begin{array}{l}\text { Alloy } \\
740\end{array}$ & 24.31 & $<1$ & $<1$ & 2 & Cr oxide enriched in $\mathrm{Ti}$ & $\begin{array}{l}\text { short oxide fingers extend into } \\
\text { matrix }\end{array}$ \\
\hline
\end{tabular}

Disbonding within Outer Oxide

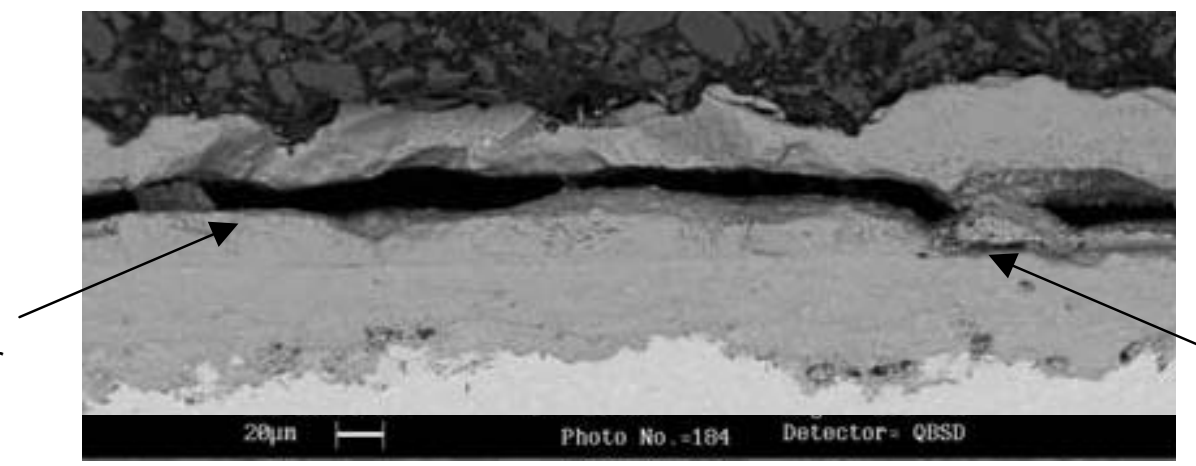

Disbonding at Interface

Figure 3. Disbonding of Outer Oxide on P92 after 4,000 Hours Exposure 
Also during this quarter, the specimens for the $800^{\circ} \mathrm{C}$ were prepared, cleaned, measured, weighed and attached to the test rack. The test facility was inspected and prepared for the $800^{\circ} \mathrm{C}$ test exposure. The first $800^{\circ} \mathrm{C}$ exposure period reached operating conditions in late February. The $800^{\circ} \mathrm{C}$ test specimens are listed in Table 9

TABLE 9

\begin{tabular}{|c|c|}
\hline \multicolumn{2}{|c|}{$800^{\circ} \mathrm{C}$ Test Materials and Number of Specimens } \\
\hline P92 (F) - 3 & T23 (F) - 3 \\
\hline $230(A)-6$ & Abe (F) -6 \\
\hline$H R-120(A)-6$ & VM12 (F) - 6 \\
\hline SAVE $25(A)-6$ & $214(A)-6$ \\
\hline CCA $617(\mathrm{~A})-6$ & $310 \mathrm{HCbN}(\mathrm{A})-6$ \\
\hline Super $304 \mathrm{H}(\mathrm{A})-6$ & $347 \mathrm{HFG}(\mathrm{A})-6$ \\
\hline Alloy $740(A)-6$ & Cr-S304H - 6 \\
\hline HR6W (A) - 6 & AlCr-S304H-6 \\
\hline SAVE $12(F)-6$ & SiCr-S304H-6 \\
\hline $304 \mathrm{H}(\mathrm{A})-6$ & Mod. $740(A)-3$ \\
\hline
\end{tabular}

\section{Concerns}

Due to inadequate funding, testing will be terminated after the first $800^{\circ} \mathrm{C}$ exposure is completed. Further analyses and test exposures will not be possible until additional funding is allocated.

\section{Activities Next Quarter}

Completion of the first $800^{\circ} \mathrm{C}$ exposure.

\section{Task 3B Coating Tests}

\section{Background}

Coated specimens for steamside oxidation testing will be prepared in conjunction with Task 7 and evaluated after testing. 


\section{Experimental}

Results from the coated specimens that were provided for the $650^{\circ} \mathrm{C}$ exposure are shown below. All remaining Cereblak specimens were returned to Steve Goodstine (Alstom). Alstom provided $\mathrm{Cr}-\mathrm{S} 304 \mathrm{H}, \mathrm{AlCr}-\mathrm{S} 304 \mathrm{H}$ and $\mathrm{SiCr}-\mathrm{S} 304 \mathrm{H}$ specimens for inclusion in the $800^{\circ} \mathrm{C}$ and $900^{\circ} \mathrm{C}$ tests. The $800^{\circ} \mathrm{C}$ coated specimens were included in the first $800^{\circ} \mathrm{C}$ test exposure.

\section{$650^{\circ} \mathrm{C}$ Weight Change and Descaled Weight Loss}

The weight change and descaled weight loss experienced by the coated P92 specimens supplied by Alstom are presented in Table 10. The weight change data collected on diffusion chromized specimens prepared by B\&W are also displayed in Table 10. The measured weight change and descaled weight loss data for these specimens have been corrected to eliminate the contribution from the base metal that was exposed during the test. [Prior to the test, a small hole was drilled through the coupons so the coupons could be wired to a test rack. Base metal was exposed along the sides of this hole.]

TABLE 10

\begin{tabular}{|c|c|c|c|c|c|c|}
\hline \multicolumn{7}{|c|}{$\begin{array}{c}\text { USC Task } 3 \text { - 650C Test } \\
\text { Weight Change and Descaled Weight Loss Results from Coated Materials }\end{array}$} \\
\hline \multirow[t]{2}{*}{ Material } & \multicolumn{3}{|c|}{ Measured Weight Change $\left(\mathrm{mg} / \mathrm{cm}^{2}\right)$} & \multicolumn{3}{|c|}{ Descaled Weight Loss ( $\left.\mathrm{mg} / \mathrm{cm}^{2}\right)$} \\
\hline & 1000 hours & 2000 hours & 4000 hours & 1000 hours & 2000 hours & 4000 hours \\
\hline CrP92 & -0.018 & 0.249 & 0.235 & 0.944 & 2.006 & -0.291 \\
\hline SiCrP92 & 0.007 & 0.308 & 0.728 & 1.193 & 2.433 & -0.173 \\
\hline AlCrP92 & 0.735 & 1.623 & 2.276 & -0.448 & 0.805 & -0.861 \\
\hline ElessNiP92 & 1.453 & 2.050 & 11.363 & ---- & 6.527 & 35.977 \\
\hline CBP92 & 3.979 & -10.286 & 1.260 & $\begin{array}{l}----- \\
\end{array}$ & ----- & ----- \\
\hline DCr602 & ----- & ----- & 0.291 & ----- & ----- & ----- \\
\hline DCrHR120 & $\begin{array}{ll}---- \\
\end{array}$ & $\begin{array}{ll}---- \\
\end{array}$ & 0.262 & ----- & ----- & ----- \\
\hline DCr253 & ----- & ----- & 0.139 & ----- & ----- & ----- \\
\hline DCr333 & ----- & ----- & 0.131 & ---- & ----- & ----- \\
\hline DCr617 & ----- & ----- & 0.273 & ----- & ----- & ----- \\
\hline DCr740 & ----- & ----- & 0.297 & ----- & ----- & ----- \\
\hline DCr353 & ----- & ----- & 0.146 & ----- & ----- & ----- \\
\hline DCr230 & ----- & ----- & 0.338 & ----- & ----- & ----- \\
\hline
\end{tabular}

The chromized specimens appeared to perform better than most of the ferritic materials, but somewhat worse than the austenitic materials. Based on weight change, the chromized specimens provided by Alstom and B\&W performed comparably; and 
somewhat better than the SiCr or AICr specimens. Descaled weight loss measurements on chromized specimens are difficult, so the accuracy of these results is suspect. The electroless nickel plated specimens have not performed as well as the chromized materials, and the Cereblak material has experienced extensive exfoliation.

\section{Metallographic Evaluation}

SEM evaluations were performed on the coated specimens removed after $\sim 4,000$ hours of exposure at $650^{\circ} \mathrm{C}$. These evaluations indicate that the CrP92 and SiCrP92 materials have a surface that is enriched in $\mathrm{Cr}$ and show essentially no oxidation. The AlCrP92 material displays a complex near-surface region containing enriched $\mathrm{Cr}$, aluminum oxides and iron oxide. The electroless Ni coated specimen displays a thick (80-100 $\mu \mathrm{m})$ iron oxide layer above a Ni/P layer, and a $\mathrm{Cr}$-rich oxide below the Ni/P layer.

\section{Concerns}

There are no concerns at this time

\section{Activities Next Quarter}

None

\section{Task 3C Assessment of Temperature}

\section{Background}

Based on the steamside oxidation test results, the practical temperature limits for the materials tested will be determined.

\section{Experimental}

No progress will be possible until results from the steamside oxidation tests at different temperatures become available.

\section{Concerns}

There are no concerns at this time

\section{Activities Next Quarter}

None 


\section{Task 3D Review of Available Information \& Reporting}

\section{Background}

Available steamside oxidation literature pertaining to materials and environmental conditions of interest will be reviewed. Project status updates will be prepared and status meetings will be attended as required.

\section{Experimental}

Monthly status reports were prepared for January and February, 2004, and a Quarterly Report was prepared for the October - December, 2003 time period.

The Steering Committee Meeting at Oak Ridge was attended. Met with lan Wright at ORNL to compare steam oxidation test results from the ORNL and BWRC test facilities.

\section{Concerns}

There are no concerns at this time.

\section{Activities Next Quarter}

Monthly status reports will be written for April and May, 2004.

A Quarterly Report will be written for January - March, 2004.

A technical paper will be prepared for the $8^{\text {th }}$ Ultra-Steel Workshop in Japan that will be presented in July.

\section{Task 3E Conduct Experimental Exposures}

\section{Background}

The steam oxidation behavior of model Fe-Cr alloys will be evaluated.

\section{Experimental}

B\&W is remaining cognizant of the ORNL tests on these model alloys.

\section{Concerns}

There are no concerns at this time 


\section{Activities Next Quarter}

None

\section{Task 3F Characterization}

\section{Background}

Samples of the model Fe-Cr alloys fabricated in Task 3E will be characterized before and after steamside oxidation testing using metallographic and electron optic techniques.

\section{Experimental}

None.

\section{Concerns}

There are no concerns at this time

\section{Activities Next Quarter}

None

\section{Task 3G Data Analysis and Coordination}

\section{Background}

The steamside oxidation results will be evaluated to determine the effects of material properties and environmental factors on oxidation behavior.

\section{Experimental}

No progress will be possible until the steamside oxidation tests have been completed (GFY2006).

\section{Concerns}

There are no concerns at this time

\section{Activities Next Quarter}

None. 


\section{Milestone Chart}

\section{Dates are listed in GFY}

\begin{tabular}{|c|c|c|c|c|c|c|c|c|}
\hline & & 2002 & 2003 & 2004 & & 2005 & \multicolumn{2}{|l|}{2006} \\
\hline ID & Task Name & \begin{tabular}{|l|l|l|l|}
$Q 1$ & $Q 2$ & $Q 3$ & $Q 4$ \\
\end{tabular} & \begin{tabular}{|l|l|l|l|}
$Q 1$ & $Q 2$ & $\odot 3$ & $Q 4$ \\
\end{tabular} & \begin{tabular}{l|l|l|l|}
$Q 1$ & $Q 2$ & $G$ \\
\end{tabular} & \begin{tabular}{l|l|}
3 & 94 \\
\end{tabular} & \begin{tabular}{|l|l|l|l|}
$Q 1$ & $Q 2$ & $Q 3$ & $Q 4$ \\
\end{tabular} & \begin{tabular}{|l|l|l|}
$Q 2$ & 03 & 04 \\
\end{tabular} & \begin{tabular}{l|l}
$Q 02$ & $Q_{2}$
\end{tabular} \\
\hline 1 & 3A Autoclave Testing & & & & & & & \\
\hline 2 & Design, Build 8 Test Facility & 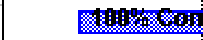 & 28tote & & & & & \\
\hline 3 & Frocure 8 Characterize Materials & 60: & rergetof & & & & & \\
\hline 4 & Design \& Euild Test Sections & & togongrimplete & & & & & \\
\hline 5 & Perform 4000 hr Test $@ 650$ \& Evaluate & & 1000 & 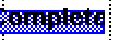 & & & & \\
\hline 6 & Perform 4000 hr Test $@ 800 \&$ Evaluate & & & 同: & Compli & 6e: & & \\
\hline 7 & Perform 4000 hr Test $(900$ \& Evaluate & & & & & & & \\
\hline 8 & 3B Coating Tests & & & & & & & \\
\hline 9 & Prepare Coupons & & 28080 & & & & & \\
\hline 10 & Post-test Evaluation & & & & 3\% Cong & Aplete, & & \\
\hline 11 & 3C Assessment of Temperature & & & & & & & \\
\hline 12 & Compile and Analyze Test Data & & & & $0 \%$ Corts & gplete, 圈. & . . & \\
\hline 13 & Determine Material Temp Limits & & & & & & i & \\
\hline 14 & 3D Literature Review \& Reporting & & & & & & & \\
\hline 15 & Literature Review & 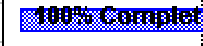 & का & & & & & \\
\hline 16 & Monthly Updates & 11111111111 & $\|1111\| 11 \|$ & |||||| & $\||| \mid$ & 111111111111 & $\| 1111111111$ & \\
\hline 77 & Quarterly Updates & 1111 & 1 & 1 & 1 & 1 & 1 & \\
\hline 96 & Meetings & 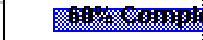 & & & & & & \\
\hline 99 & 3E Model Fe-Cr Alloys & & & & & & & \\
\hline 100 & Cognizance of ORNL Activities & 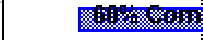 & 3600 & & & & & \\
\hline 101 & 3F Characterize Model Fe-Cr Alloys & & & & & & & \\
\hline 102 & Cognizance of ORNL Activities & $600 \%$ & thex & & & & & \\
\hline 103 & 3 G Data Anabsis & & & & & & & \\
\hline 104 & Compile \& Analyze Data & & & & & & (1) & \\
\hline 105 & Determine Rate Laws vs. Composition & & & & & & 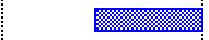 & \\
\hline
\end{tabular}




\section{Task 4 \\ Fireside Corrosion (Foster Wheeler)}

The objective of the task is to evaluate the relative resistance of various advanced alloys for waterwall and reheater/superheater construction to fireside corrosion over the full temperature range expected for the USC plant. The corrosive environment promoted by three different coals, representative of an eastern coal, a Midwestern coal, and a western coal, will be evaluated.

\section{Task 4A: Laboratory Testing}

\section{Objectives}

The objective of this sub-task is to perform laboratory corrosion tests on the candidate alloys. This will be accomplished by exposing metal coupons to various deposits and flue gases representative of three coals (e.g., eastern, Midwestern, and western) at the range of temperatures expected for the USC plant.

\section{Progress for the Quarter}

- The test materials have been procured and the coupons prepared. The materials are listed in Tables 1 (WW) and $2(\mathrm{RH} / \mathrm{SH})$.

TABLE 1

\begin{tabular}{|c|c|}
\hline \multicolumn{2}{|c|}{ SUMMARY OF WATERWALL MATERIALS } \\
\hline T2 & 622 Weld Overlay \\
\hline P92 & 72 Weld Overlay \\
\hline SAVE 12 & 52 Weld Overlay \\
\hline T22 & T92 w/Chromized coating \\
\hline T23 & T92 w/AlCr coating \\
\hline HCM12A (P122) & T92 w/SiCr coating \\
\hline Abe Alloy & $50 / 50$ Laser clad \\
\hline
\end{tabular}


TABLE 2:

\begin{tabular}{|c|c|c|}
\hline \multicolumn{3}{|c|}{ SUMMARY OF REHEATER/SUPERHEATER MATERIALS } \\
\hline 230 & 120 & SAVE 25 \\
\hline 617 & Super 304 & IN740 \\
\hline HR6W & 304 & 347HFG \\
\hline HR3C & 214 & RA602CA \\
\hline RA353 & Nimonic 263 & $800 \mathrm{HT}$ \\
\hline $45 \mathrm{TM}$ & HCM12A & Abe Alloy ${ }^{1,2}$ \\
\hline 622 Weld Overlay ${ }^{2}$ & 72 Weld Overlay $^{2}$ & 52 Weld Overlay ${ }^{2}$ \\
\hline $\mathrm{S} 304 \mathrm{w} / \mathrm{FeCr}$ & S304 w/AICr & S304 w/SiCr \\
\hline \multicolumn{3}{|l|}{$50 / 50{\text { Laser } \text { Clad }^{2}}^{2}$} \\
\hline \multicolumn{3}{|c|}{${ }^{1}$ Tested only at $1200^{\circ} \mathrm{F}$ condition. } \\
\hline \multicolumn{3}{|c|}{${ }^{2}$ Tested under all Waterwall conditions (i.e., 850, 975, \& 1100 F). } \\
\hline
\end{tabular}

- Six furnaces were set up for testing: three will be utilized for waterwall conditions and three for reheater/superheater conditions.

- Deposit and flue gas compositions were finalized for both waterwall and reheater/superheater conditions for the three types of coal. Carbon will be added to both types of deposit to evaluate for carburization of the test materials. The deposit and flue gas compositions are given in Tables 3 through 6 .

TABLE 3

\begin{tabular}{|c|c|c|c|}
\hline \multicolumn{5}{|c|}{ WATERWALL DEPOSIT COMPOSITIONS } \\
\hline Dopant & $\begin{array}{c}\text { Typical Eastern Coal } \\
\text { (Pitt \#8) } \\
\text { (wt.-\%) }\end{array}$ & $\begin{array}{c}\text { Typical Mid-Western Coal } \\
\text { (ILL \#5) } \\
\text { (wt.-\%) }\end{array}$ & $\begin{array}{c}\text { Typical Western Coal } \\
\text { (PRB) } \\
\text { (wt.-\%) }\end{array}$ \\
\hline $\mathrm{FeS}$ & 40 & 75 & 0 \\
\hline $\mathrm{CaSO}$ & 0 & 0 & 20 \\
\hline $\mathrm{Cl}($ e.g., $\mathrm{NaCl}+\mathrm{KCl})$ & 0.2 & 0.5 & 0.1 \\
\hline $\mathrm{C}$ & 5 & 5 & 5 \\
\hline $\mathrm{Fe}_{3} \mathrm{O}_{4}$ & 45 & 10 & 5 \\
\hline $\mathrm{Al}_{2} \mathrm{O}_{3}+\mathrm{SiO}_{2}$ & $\mathrm{Bal}\{1: 1\}$ & Bal $\{1: 1\}$ & Bal $\{1: 1\}$ \\
\hline
\end{tabular}


TABLE 4

\begin{tabular}{|c|c|c|c|}
\hline \multicolumn{4}{|c|}{ WATERWALL FLUE GAS COMPOSITIONS } \\
\hline \multicolumn{4}{|c|}{ The base composition of the synthetic flue gas will be a mixture of: } \\
\hline \multicolumn{4}{|c|}{ Typo $+6 \% \mathrm{H}_{2} \mathrm{O}+17 \% \mathrm{CO}_{2}+\mathrm{BAL} \mathrm{N}_{2}+\ldots$} \\
\hline Dopant & $\begin{array}{c}\text { (Pitt \#8) } \\
\text { (vol.-\%) }\end{array}$ & $\begin{array}{c}\text { (ILL \#5) } \\
\text { (vol.-\%) }\end{array}$ & $\begin{array}{c}\text { Typical Western Coal } \\
\text { (PRB) }\end{array}$ \\
& 0.12 & 0.37 & 0.067 \\
\hline $\mathrm{SO}_{2}$ & & (vol.-\%) & Typical Mid-Western Coal \\
\hline
\end{tabular}

TABLE 5

\begin{tabular}{|c|c|c|c|}
\hline \multicolumn{4}{|c|}{ REHEATER/SUPERHEATER DEPOSIT COMPOSITIONS } \\
\hline Dopant & $\begin{array}{c}\text { Typical Eastern Coal } \\
\text { (Pitt \#8) } \\
\text { (wt.-\%) }\end{array}$ & $\begin{array}{c}\text { Typical Mid-Western Coal } \\
\text { (ILL \#5) } \\
\text { (wt.-\%) }\end{array}$ & $\begin{array}{c}\text { Typical Western Coal } \\
\text { (PRB) } \\
\text { (wt.-\%) }\end{array}$ \\
\hline Alkali Sulfates & 5 & 10 & 0 \\
\hline $\mathrm{CaSO}_{4}$ & 0 & 0 & 20 \\
\hline $\mathrm{C}$ & 2.5 & 2.5 & 2.5 \\
\hline $\mathrm{Fe}_{2} \mathrm{O}_{3}+\mathrm{Al}_{2} \mathrm{O}_{3}+\mathrm{SiO}_{2}$ & $\mathrm{Bal}\{1: 1: 1\}$ & Bal $\{1: 1: 1\}$ & Bal $\{1: 1: 1\}$ \\
\hline
\end{tabular}

TABLE 6

REHEATER/SUPERHEATER FLUE GAS COMPOSITIONS

The base composition of the synthetic flue gas will be a mixture of: $3.6 \% \mathrm{O}_{2}+10 \% \mathrm{H}_{2} \mathrm{O}+15 \% \mathrm{CO}_{2}+\mathrm{BAL} \mathrm{N} \mathrm{N}_{2}+\ldots$

\begin{tabular}{|c|c|c|c|}
\hline Dopant & $\begin{array}{c}\text { Typical Eastern Coal } \\
\text { (Pitt \#8) } \\
\text { (vol.-\%) }\end{array}$ & $\begin{array}{c}\text { Typical Mid-Western Coal } \\
\text { (ILL \#5) } \\
\text { (vol.-\%) }\end{array}$ & $\begin{array}{c}\text { Typical Western Coal } \\
\text { (PRB) } \\
\text { (vol.-\%) }\end{array}$ \\
\hline $\mathrm{SO}_{2}$ & 0.20 & 0.35 & 0.05 \\
\hline $\mathrm{Cl}$ & 0.01 & 0.02 & 0.00 \\
\hline
\end{tabular}

- The first 1000-hour test cycle commenced on March 8. The test temperature for this cycle is $850^{\circ} \mathrm{F}$ for waterwall conditions and $1200^{\circ} \mathrm{F}$ for reheater/superheater conditions. Since six furnaces are available, the deposit/flue gas combinations for the three types of coal will be tested simultaneously for each condition. The deposit will be replenished every 100 hours to in order to keep an active corrodent on the surface of the coupons. The representative appearance of a set of coupons during a deposit replenishment interval is illustrated in Figure 1. 


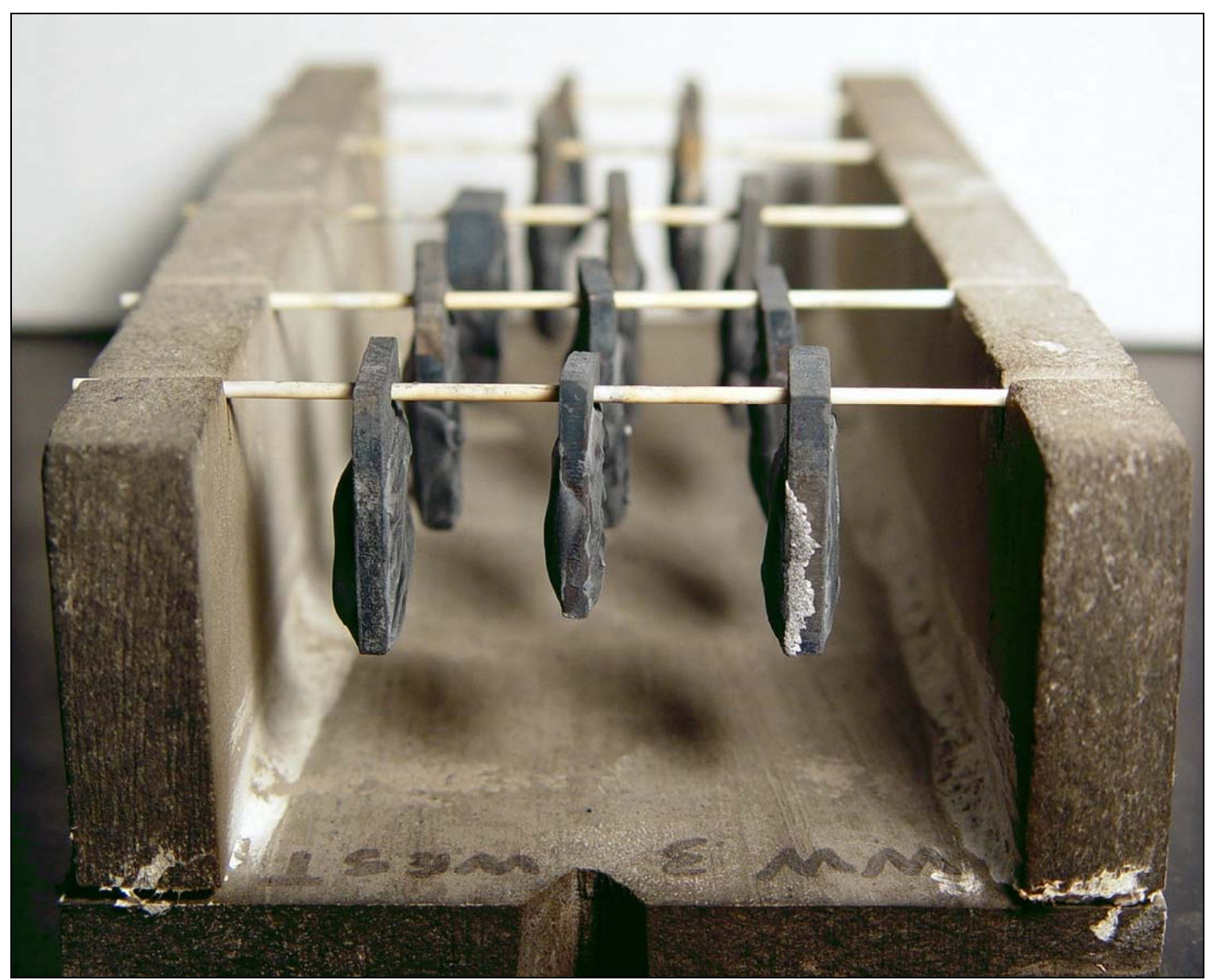

Figure 1. Representative appearance of the coupons coated with deposit and arranged on the test platform.

\section{Concerns}

- No concerns at this time.

\section{Plans for the Next Quarter}

- Finish 1000 hour cycle at $850^{\circ} \mathrm{F}$ for waterwall samples and $1200^{\circ} \mathrm{F}$ for reheater/superheater samples.

- Start analyzing coupons from first 1000 hour cycle.

- Start second 1000 hour test cycle at higher temperatures. 


\section{Task 4B: Corrosion Probe Testing in Utility Boilers}

\section{Objective}

The objective of this sub-task is to install corrosion probes comprised of various alloys/coatings/weld overlays at three coal-fired power plants and control them in the temperature range expected for reheater/superheater components in the USC plant. The plants should burn coals representative of the three types specified earlier.

\section{Progress for the Quarter}

- Three host utilities were identified: First Energy's Burger Station - burning a 70/30 blend of eastern and PRB coal; Cinergy's Gibson Station - burning a Midwestern coal; and Xcel Energy's Pawnee Station - burning a western (PRB) coal.

- Host Utility Work Agreements were finalized.

- Design of probe and retraction mechanisms was initiated; a conceptual illustration of the retraction mechanism is shown in Figure 2.

- Tube materials for probe samples are being procured; discussions with B\&W and Alstom for the weld overlay and coated samples are ongoing.

- Further design work, assembly, testing, and subsequent installation of theprobes are on hold - waiting additional funding.

\section{Concerns}

- Funding needs to be moved forward to build and install probes in the current fiscal year.

\section{Plans for the Next Quarter}

- Purchase equipment and materials for fabrication of probes (if funding becomes available).

- Commence fabrication of probes and retraction mechanism (if funding becomes available). 


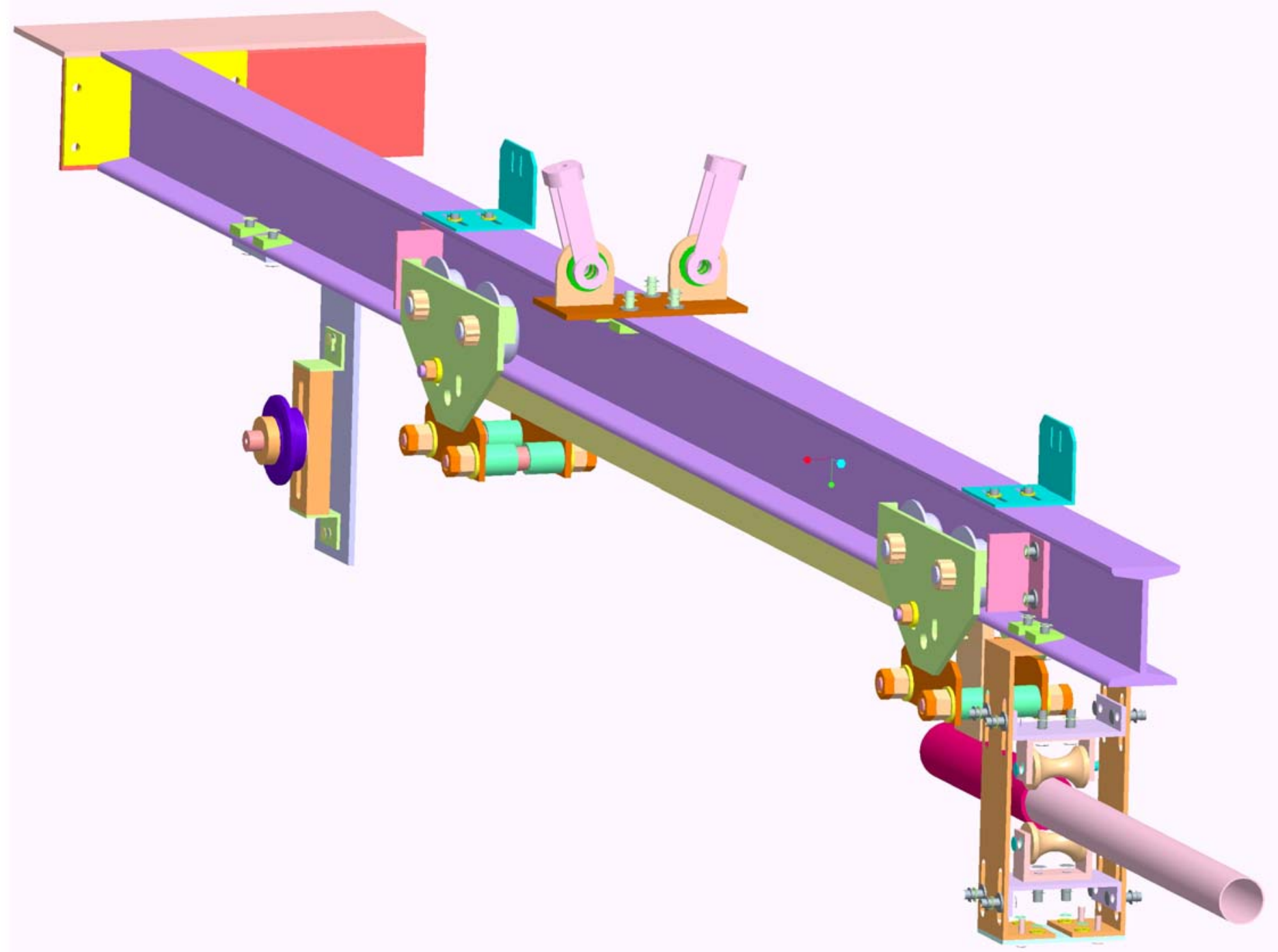

Figure 2. Conceptual illustration of corrosion probe retraction mechanism. 


\section{Task 4C: Steam Loop Design, Construction, and Testing (B\&W and Riley Power)}

\section{Objectives}

- The objectives of this subtask are to design, build, and test two experimental USC steam loops that will operate in a commercial boiler at metal temperatures up to $1400^{\circ} \mathrm{F}$. The elements of this subtask include the following:

- Design and construct two test loops using commercially available, high temperature corrosion-resistant alloys selected for the USC Plant.

- Install and operate the test loops at the Reliant Electric power plant, located in Niles, $\mathrm{OH}$ and burning high sulfur Ohio coal, and at another utility.

- Test and monitor the relative performance of the USC tube alloys, coatings, claddings, and weld overlays, which comprise the test loops for a period of 18 to 24 months.

\section{Progress for the Quarter}

With regard to the test loop at the Reliant Plant:

- The two steam loops were installed in the unit - materials in the loop include 230, 740, CCA617, HR6W, Super 304H, RA333, SAVE 12, and weld overlays 52, 72, and 622.

- The unit was restarted December 21. Steam temperature is being controlled to $1000^{\circ} \mathrm{F}$ by the inlet flow control valve until the attemperator controls can be verified on-line.

- Steam loop has operated for most of the quarter at metal temperatures below the $1400^{\circ}$ maximum target value. Modifications of the thermocouples on the outlet tubes in combination with attemperator tuning should promote higher metal temperature of the samples.

With regard to the second test loop:

- Negotiations with Dairyland Power were discontinued, leaving the installation of a steam loop at another utility in doubt.

\section{Concerns}

- Securing another utility for the second steam loop.

\section{Plans for Next Quarter:}

- Continue to monitor the operating conditions at the Niles steam loop; make thermocouple modifications and tune attemperator to produce higher metal temperatures of the samples. 
- Come to some resolution concerning the installation of a steam loop at a second utility. 


\section{Task 5 \\ Welding Development \\ (Alstom)}

\section{Objectives}

The major objectives for Task 5: Welding Development are:

- To define weld metal choices for candidate materials.

- To establish acceptable welding procedures and practices.

- To evaluate the effects of manufacturing heat treatments and preheat and post weld heat treatments on weldment integrity and properties.

- To produce samples needed to determine the properties of candidate ultrasupercritical alloy welds and weldments, including the dissimilar metal weld joint between the various types of material (the actual mechanical and property testing will be performed under Task 2).

These objectives will be accomplished through execution of five sub-tasks. Where activity on these sub-tasks occurred during the reporting period, it is described below.

\section{Task 5A: Selection of Weld Filler Material}

\section{Objectives}

The primary objective of this subtask is to select and procure appropriate filler materials for each of the welding processes to be studied. However, procurement of base materials and general planning of task activities are also included.

\section{Progress for the Quarter}

- Matching filler metals were obtained for making joints in HR6W tubing and procedures similar to those using Inconel 82 and 617 fillers can now be developed.

- Delivery of matching filler metals for the SAVE 12 weld joints was delayed and welding procedure development will not start until April 2004.

- Efforts to obtain filler metal from Sumitomo for gas metal arc welding of Super 304H tubes have been unsuccessful but are continuing. 


\section{Concerns}

The following concerns have been expressed before and are not new.

- Base material sourcing difficulties and long delivery times have, in some cases, delayed the start of welding activities by 9 to 12 months.

- The unexpectedly high cost of the nickel base alloys will cause the material budgets to be exceeded and might result in program cost overruns and/or reductions in program scope.

\section{Plans for the Next Quarter}

Continue efforts to procure matching filler metals for the HR6W, SAVE 12, and Super $304 \mathrm{H}$ materials.

\section{Task 5B: Optimization of Weld Parameters}

\section{Objective}

The primary objectives of this subtask are to establish the baseline welding parameter values for each material/process/product form combination being studied. Included is the development of preheat and post weld heat treatment requirements.

\section{Progress for the Quarter}

- SAVE 12:

Thirty-five tubes (2-inch OD X 0.4-inch MWT X 34-inch length) were machined from heavy wall pipe to produce a smaller tubular product form for welding trials. Sumitomo recommended that the tubes be normalized and tempered before any further work is attempted and this will delay the start of welding by a few weeks.

\section{- HR6W:}

Two welding processes were qualified for joining tubing using Inconel 617 filler metals: a gas metal arc process and a combination gas tungsten arc root and shielded metal arc fill process.

- Super 304H:

Tube butt joint samples were prepared using the gas tungsten arc process that had been qualified.

- CCA 617 (known in Europe as Marcko):

- Plate butt joint samples were prepared using the submerged arc process that had been qualified. 
- Attempts to weld plate using SMAW with matching filler were unsuccessful because of poor weldability (slag control) exhibited by the electrodes. However, a process was "qualified" using an out-of-position geometry with the matching electrodes and plate butt joint samples were prepared to provide test specimens for study.

- Conventional Inconel 617 electrodes had good weldability but plate weldments failed bend qualification tests and this issue is being pursued with Special Metals.

- Haynes 230:

A gas metal arc process was marginally successful in producing a butt joint in 3-inch thick plate. Another joint is planned to produce material for test specimens but funding issues must be resolved before welding can begin.

- Inconel 740:

- Attempts at making gas metal arc welds in 3-inch thick plate have been unsuccessful because lack of ductility has resulted in bend test failures. This problem occurred with weldments in both the as-welded and aged conditions.

- Trials were also conducted on plates using a helium gas tungsten arc process that had shown earlier success in reducing cracking in nickel base welds. Various combinations of aging, overaging, low heat input, and high heat input were used. The best results were obtained by overaging the base material before welding, using a low heat input process, and overaging the completed weldment. Marginal, but acceptable, results were obtained by overaging the base material, using a high heat input process, and employing a standard aging treatment on the completed weldment. Obviously, the latter would be more acceptable because of the higher filler metal deposition rate afforded by the high heat input process. However, although overaging did not appear to affect the tensile properties of the weldments, the effects on creep behavior in either of these procedures is unknown and would have to be explored.

- Funding issues have prevented further welding process development.

\section{Concerns}

- Submerged arc welding, a high deposition rate process favored by boilermakers for thick sections, does not appear feasible for all nickel base materials. Tests on Haynes 230 and Inconel 740 have been unsuccessful because of cracking and the process is being abandoned on these two alloys.

- The unexpectedly high cost of the nickel base alloys will cause the material budgets to be exceeded and might result in program cost overruns and/or reductions in program scope. 
- Funding issues have developed that must be resolved before any further welding development on the Haynes 230 and Inconel 740 alloys can continue.

\section{Plans for the Next Quarter}

- Resolve funding issues regarding Haynes 230 and Inconel 740 welding development.

- Begin welding efforts on tubes machined from SAVE 12 pipe.

- Qualify HR6W tube butt weld processes using matching filler metal.

- Continue trying to obtain information on gas metal arc welding of Super $304 \mathrm{H}$.

- Fabricate CCA 617 tube test specimens using gas tungsten arc process.

- Continue to study problems with shielded metal arc welding of CCA 617 thick plates.

- Begin fabrication of Super 304H/CCA 617 and Super 304H/T91 dissimilar metal weld joints. 
Task 5: Welding Development - Milestone Chart

(DOE Fiscal Year Basis)

\section{(percentages indicate fraction of workscope completed as of 2004Q2)}

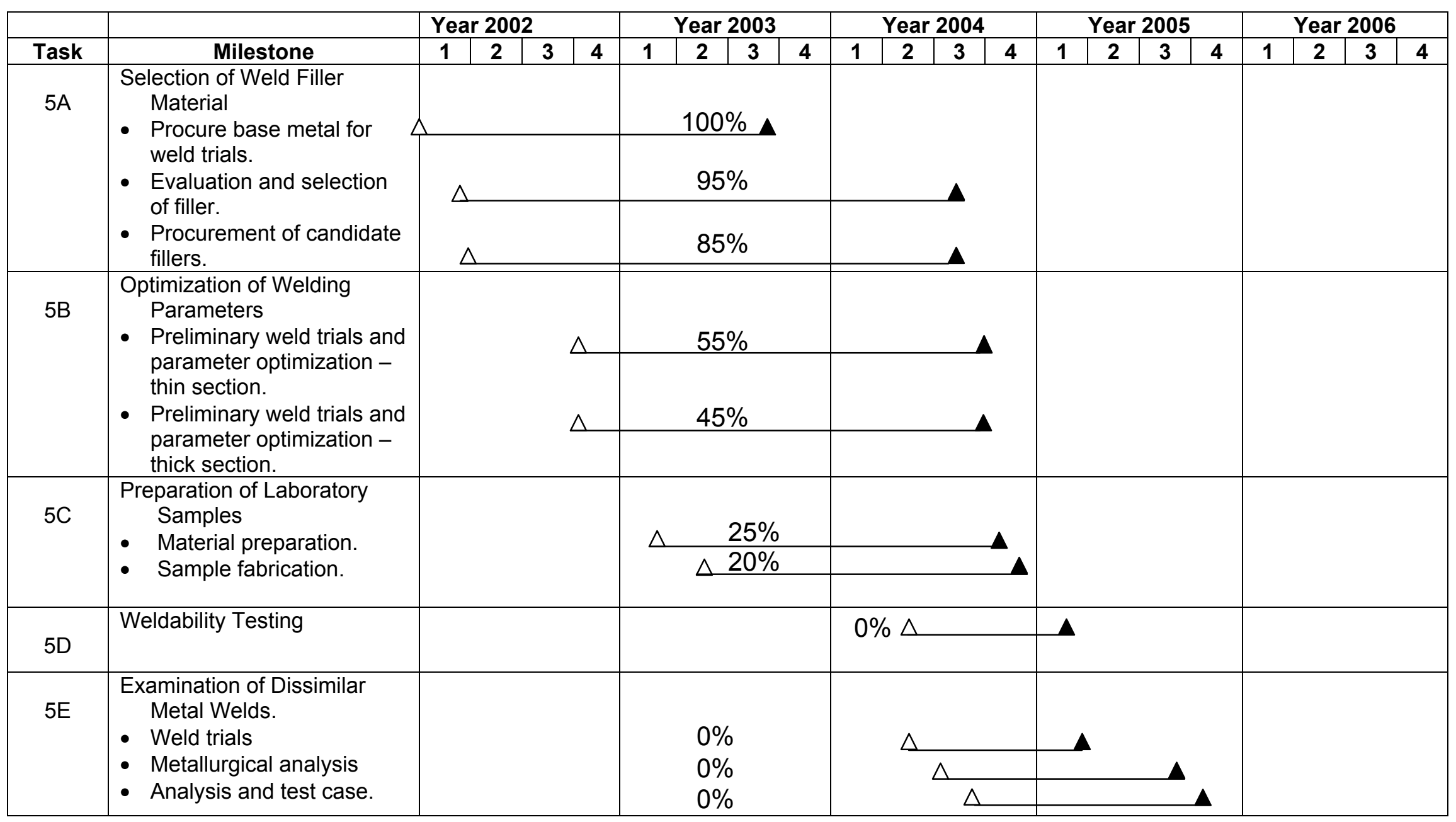




\section{Accomplishments Versus Expenditures}

(Astom)

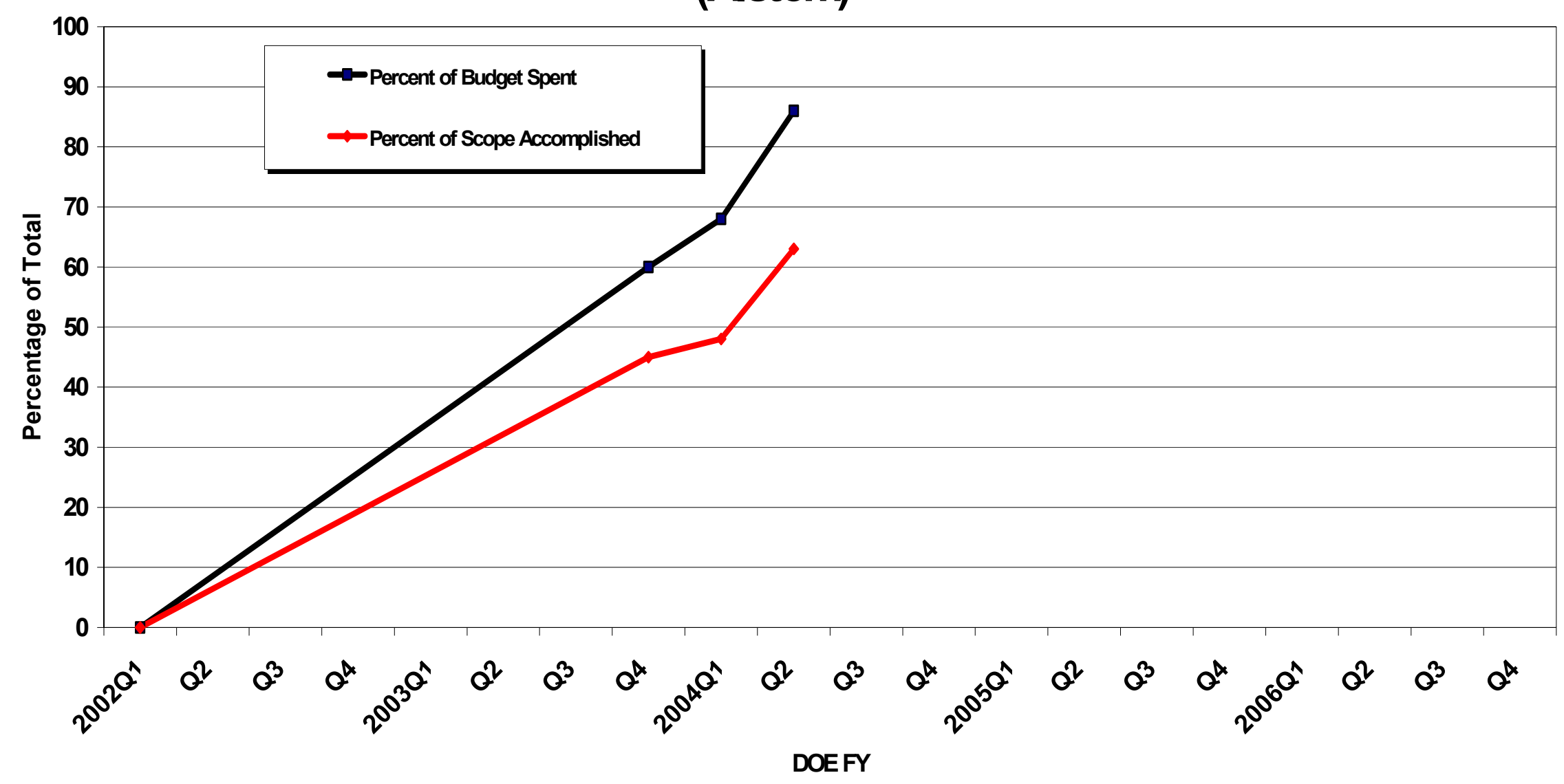




\section{Task 6 Fabrication}

\section{Objectives}

- The objective of Task 6 is to establish boiler fabrication guidelines for the high temperature, corrosion resistant alloys selected for the USC Project. The principal goals in this joint effort are:

- To establish fabrication guidelines for the high temperature, corrosion resistant alloys needed for boiler components in the USC power plant.

- $\quad$ To determine the thermomechanical treatments or other remedial actions necessary to restore material properties which might degrade due to fabrication operations.

- To investigate prototypical manufacturing operations for producing both thick wall and thin wall components from the USC alloys.

\section{Progress for the Quarter: Riley Power, Inc.}

- A plan was established by Riley Power Inc. for the evaluation of the HR6W and SAVE12 materials and submitted to Task 6 members. The plan involved bending tests, PWHT requirements, machining, swaging, drilling, cutting and pressing operations. As of this report, Riley Power Inc. has completed a series of bends and swaging operations related to the fabrication of HR6W. Tube bends of the HR6W materials have been made with strain levels of $15 \%, 20 \%$ and $35 \%$.

- Riley has also submitted the list of questions to Sumitomo, the supplier of HR6W and SAVE 12, to gain information on hot and cold working characteristics, thermal treatment, machining characteristics, welding, PWHT and other thermal treatment requirements necessary to fabricate boiler components from these alloys. Sumitomo has responded with some of the information requested.

- Riley Power Inc. has experienced some delays in performing the Task 6 effort with SAVE12 pipe material. Riley Power Inc. had proposed the machining of 2" OD x .400" tube samples from spool piece sections of the SAVE12 heavy wall pipe obtained from the original Sumitomo order. This would involve having sections of the SAVE12 material sliced or cut from a spool piece of the 13 " OD $\times 2.00$ " min. wall pipe spools in order to produce a solid bars of the SAVE12 material and machining and boring the bar[s] to produce a 2" OD $x$ .400" wall SAVE12 tubes. The machining of the SAVE12 large OD / heavy wall pipe to produce 2" OD x .400" wall tubes of the SAVE12 has taken longer than expected, but was completed in February 2004. 


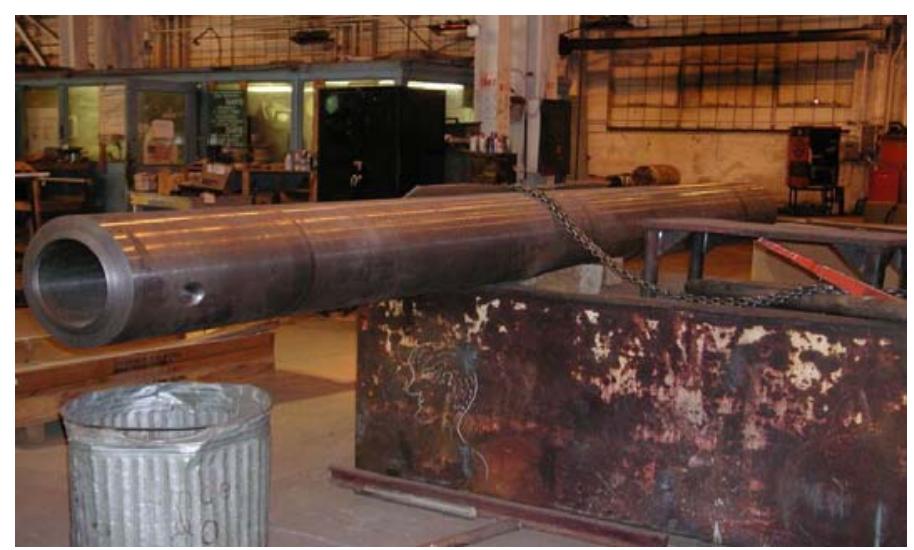

SAVE12 pipe that was procured from Sumitomo for the USC Project.

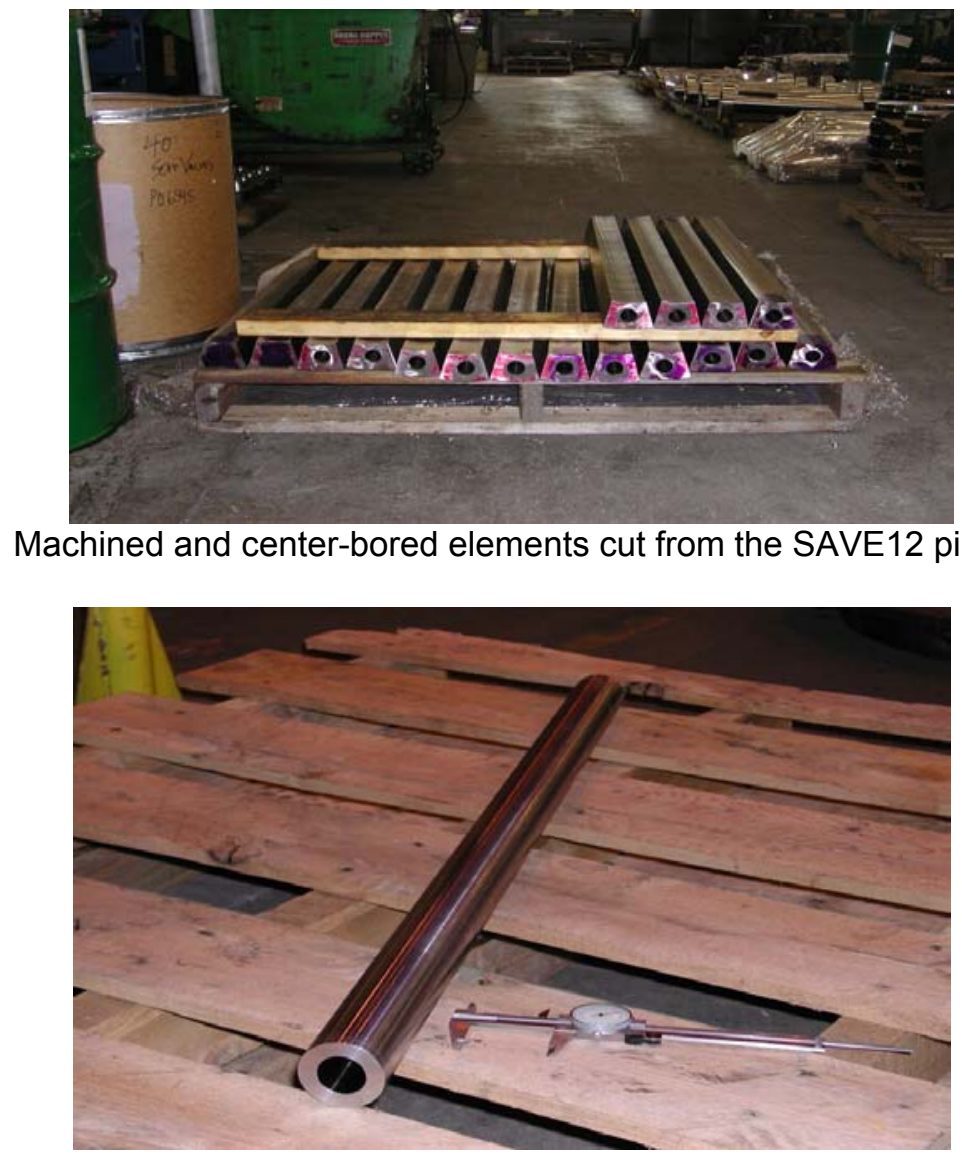

Final machined SAVE12 tube, 2" OD X 0.400" MW.

- As of March 2004, RPI has received the 2" OD x .400" wall tubes machined from the SAVE12 material at our shop. There are 35 tubes approximately 34 " in length. There have been no problems with the machining characteristics of the SAVE12 material. Sumitomo has suggested a need to normalize and temper these tubes prior to weld testing or bending / swaging tests due to the metallurgical changes 
which have occurred in the machining [cold working] of the tubes from the large pipe spools. RPI has scheduled this work early in April in order that we can proceed with the bending and swaging tests of the SAVE12.

- Riley Power Inc. is currently awaiting the reports from Foster Wheeler regarding the with sample materials of the HR6W and SAVE12 materials in order to perform the recrystallization studies on these materials. Riley has agreed to send Foster Wheeler a 2" OD $x$.400" wall tube of the SAVE12 as described above. This will allow the recrystallization study to be conducted on a 2" OD SAVE12 tube rather than the solid strip of SAVE12 pipe material originally sent to Foster Wheeler.

\section{Concerns}

None.

\section{Plans for the Next Quarter}

- Continue fabrication trials with the HR6W and SAVE12.

- Assess the recrystallization response of strained HR6W and SAVE12 materials based on data generated at Foster Wheeler.

\section{Progress for the Quarter: Alstom Power, Inc.}

- Information was obtained from Special Metals regarding the fabricability of nickel base alloys in general and Inconel $® 617$ specifically. This information will be used to plan the details of fabricability tests on CCA 617 since the composition of the latter alloy falls within the specification for Inconel 817.

- Material was prepared and tooling was identified to make the series of Super $304 \mathrm{H}$ and CCA $617 \mathrm{U}$-bend specimens required for Task 2 testing.

- Sectioning procedures and heat treatment details were developed for processing the tapered tubes to be used for cold working studies.

- Details of the swaging process to be used to determine the sensitivity of Super $304 \mathrm{H}$ to strain induced embrittlement were developed.

\section{Concerns}

None.

\section{Plans for the Next Quarter}

- $\quad$ Make the series of Super 304H and CCA 617 U-bend specimens required for Task 2 testing. 
- Complete the heat treating and examination of the tapered tubes used for the cold working studies.

- $\quad$ Determine the sensitivity of Super $304 \mathrm{H}$ to strain-induced embrittlement.

\section{Alstom Financials:}

- $\quad$ The efforts to date have been concentrated on planning, reporting, material procurement, and tapered specimen preparation and have resulted in a completion of $\sim 15 \%$ of the workscope. These efforts have consumed $\sim \$ 36,000$ or $\sim 18 \%$ of the $\$ 200 \mathrm{~K}$ budget. While the expenditures are slightly ahead of commensurate accomplishments, the deviation is not significant enough to warrant concern at this time.

\section{Progress for the Quarter: Foster Wheeler}

\section{Recrystallization Study:}

- Strained tapered tube specimens were fabricated from 230, 740, and HR6W material. Previously, we had strained tapered tubes fabricated from super $304 \mathrm{H}$ and CCA617 and sent them to Alstom in December without any further analysis. We still need to strain the SAVE12 material, and I am waiting for Brian Holbrook to sent me one of the tubes he machined from the heavy wall pipe section, but we discovered it needs to be heat treated.

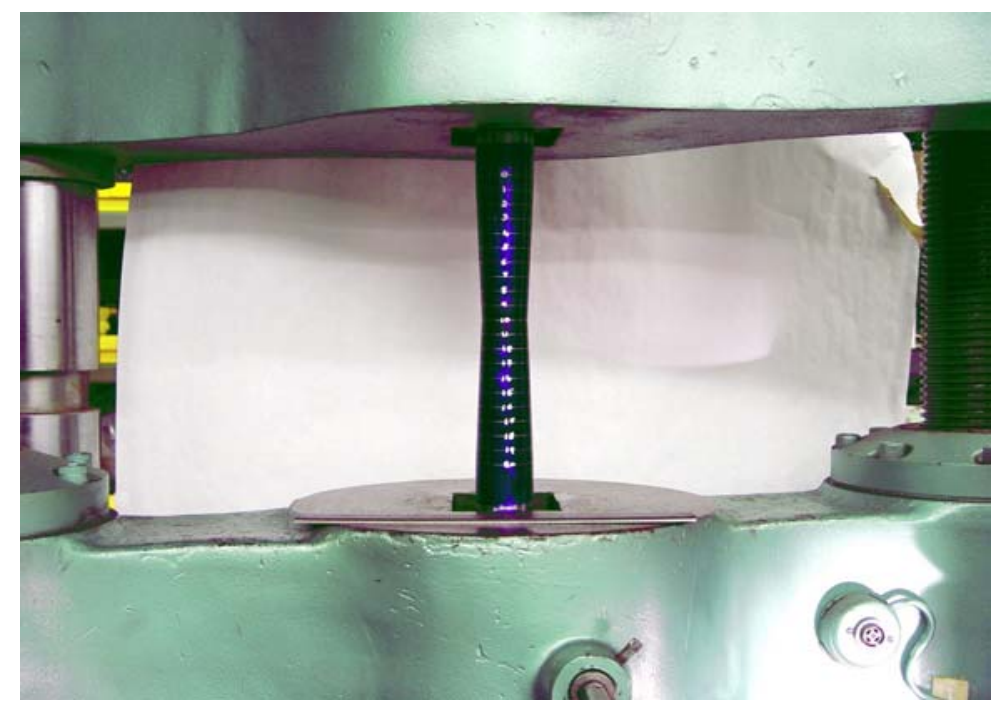

Controlled straining of a tapered tube specimen for recrystallization studies 
- We longitudinally sectioned the 230,740 , and HR6W specimens to measure wall thickness at each gage mark in order to calculate the cross sectional area at these locations after straining. Knowing the cross-sectional areas before (B) and after (A) straining, the true strain (TS) at each location can be calculated using the following relationship: $\log _{n}$ (area B/area $\left.A\right)$. Once the TS is known, a correlation with outer fiber strain (OFS), such as in a bend, can be made by the following: \% OFS = [e(TS) - 1] X100.

- Using this approach, the following range of results were calculated for the three materials:

\begin{tabular}{llll} 
Material & \multicolumn{1}{c}{ \% RA } & \multicolumn{1}{c}{ TS } & \multicolumn{1}{c}{ OFS } \\
230 & $0-29.5$ & $0-0.349$ & $0-41.8$ \\
740 & $0.23-29.8$ & $0.002-0.354$ & $0.2-42.5$ \\
HR6W & $0-32.5$ & $0-0.392$ & $0-48$
\end{tabular}

- We are in the process of preparing metallurgical mounts containing samples that comprise the full range of strain values and will then characterize the material (microhardness and microstructure) at the ten gage marks representing the full range of strains.

- I discussed these results and the methodology with Mike Borden and Jim Tanzosh at the meeting in Oak Ridge. We all agreed that the next step would be to perform some thermal exposures. In a discussion I had with Mike, we talked about exposing one section at the expected maximum operating metal temperature of the alloy in the USC unit for 100 hours to see if we have any major problems with the high strain levels causing recrystallation at operating temperature. If we proceed with this testing, we need to know what metal temperatures (for thermal exposure) should be selected for the various alloys. The other exposure temperature will need to be determined through discussions amongst ourselves and the alloy suppliers.

\section{Fabrication of 740 :}

- Since the supplied tubing does not have a relatively uniform hardness around the circumference (in three quadrants the hardness is 85 - $86 \mathrm{HRB}$, whereas in the fourth, the hardness is 96 - $97 \mathrm{HRB}$ ), we may need to have it resolution annealed by Special Metals. The theory is that the zone of harder material aged somewhat on cooling when the tubing was being processed. I don't want to conduct any Ubending trials (similar to what was done with the 230 and the HR6W) with material that may not be representative of commercial tubing. I also don't know how this material will behave in the bender. I talked with Gaylord Smith of Special Metals at Oak Ridge, and he asked me to let him know how much tubing I have for re-solution annealing before he would commit to doing it. So, we need to resolve this issue before we can move forward. Incidentally, I will probably contract Riley to do the bending at their Erie Shop, so we can use the same dies as they used to get the desired strain levels. 


\section{Concerns}

None.

\section{Plans for the Next Quarter}

- Characterize materials (microstructure and hardness) in the as-strained condition.

- $\quad$ Research and finalize exposure temperatures/times for the strained specimens.

\section{Progress for the Quarter: B\&W}

- $\quad$ Three alloy 230 U-bend samples (having 13\%, 20\%, and 33\%) that were produced last June in a B\&W production facility were sent to ORNL for pressurized creep testing.

- A revised questionnaire on material fabricability, to be sent to USC alloy suppliers, was prepared and distributed to Task 6 participants.

- B\&W's Task 6 workscope activities and available funding were reviewed.

- An abstract and paper entitled, "Considerations in Fabricating USC Boiler Components from High Temperature Materials" were prepared for presentation at the $4^{\text {th }}$ International Conference on Advances in Materials Technology for Fossil Power Plants, scheduled for presentation in October, 2004.

\section{Concerns}

- Some B\&W Task 6 workscope activities may have to be deferred until the beginning of GFY 2005 to adjust to the current funding rate in the project.

\section{Plans for the Next Quarter}

- Techical information concerning the deformation processing and thermal treatment of alloy 230 will continue to be reviewed.

- All other Task 6 activities at B\&W will remain on hold, pending resolution of funding issues. 


\section{Task 6 Schedule and Progress}

\begin{tabular}{|c|c|c|c|c|c|c|c|c|c|c|c|}
\hline & & & & & 2000 & 2001 & 2002 & 2003 & 2004 & 2005 & 2006 \\
\hline ID & Task Name & Start & Finish & Status & \begin{tabular}{|l|l|l|l|} 
Q1 & Q2 & Q3 & Q4 \\
\end{tabular} & \begin{tabular}{|l|l|l|l|} 
Q1 & 02 & 03 & 04 \\
\end{tabular} & \begin{tabular}{|l|l|l|l|} 
Q1 & Q2 & Q3 & Q4 \\
\end{tabular} & \begin{tabular}{|l|l|l|l|}
$Q 1$ & $Q 2$ & $Q 3$ & $Q 4$ \\
\end{tabular} & \begin{tabular}{ll|l|l|l|} 
Q1 & Q2 & Q3 & Q4 \\
\end{tabular} & \begin{tabular}{|l|l|l|l|} 
Q1 & Q2 & Q3 & Q4 \\
\end{tabular} & \\
\hline 2 & 6A: Fab Trials for SH & Wed $1 / 2,02$ & Tue $11 / 30,04$ & In Progress & & & & & & & \\
\hline 3 & 6A.1 SH Trial & Tue $1 / 1 / 02$ & Thu 9/9/04 & In Progress & & & & & & & \\
\hline 4 & Procure Materials & Wed 1/2/02 & Fri 5/30/03 & Complete & & & & & & & \\
\hline 5 & Shop Sched \& Graphics & Tue $4 / 103$ & Mon $6 / 2,03$ & Complete & & & & $=$ & & & \\
\hline 6 & Travel to Shop & Mon 6/2:03 & Fri 6/4/04 & In Progress & & & & & 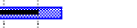 & & \\
\hline 7 & Cold Bending Trials & Mon 6/203 & Fri 6/4,04 & In Progress & & & & & & & \\
\hline 8 & Cold Swaging Trials & Mon 6/2/03 & Fri $6 / 4,04$ & In Progress & & & & & & & \\
\hline 9 & Butt Welding Trials & Mon 6/203 & Fri 6:4,04 & In Progress & & & & & & & \\
\hline 10 & Attachment Welding Trials & Mon $6 / 2,03$ & Fri $8,6,04$ & In Progress & & & & & & & \\
\hline 11 & 6A.2 Reporting & Fri $1 / 3 / 03$ & Fri 12/304 & In Progress & & & & & & & \\
\hline 12 & 6A.3 SH: Met Test 8 Eval & Fri $1: 904$ & Fri 81604 & In Progress & & & & & $=$ & & \\
\hline 13 & 6A.3.1 Mic Bends\&Welds & Fri $6: 4,04$ & Wed $7 / 28,04$ & Planned & & & & & $\square$ & & \\
\hline 14 & 6A.3.2 HT Studies\&Mic & Fri 6/4/04 & Thu 8/19/04 & Planned & & & & & $\square$ & & \\
\hline 15 & 6B: Fab Thk Wall Comp & Thu $1 / 2 / 03$ & Thu $3 / 31 / 05$ & Planned & & & & & & & \\
\hline 16 & 68.1 Thick-Wall Fab Trial & Fri $1 / 904$ & Mon 6/21:04 & In Progress & & & & & & & \\
\hline 17 & 68.2 Reporting & Fri 19,0404 & Thu $3 / 31,05$ & In Progress & & & & & & & \\
\hline 18 & 68.3 Thick-Mall Comp & Fri $1,9,04$ & Fri 10/29:04 & In Progress & & & & & & & \\
\hline 19 & 6B.3.1 Met Analysis & Wed 9/29/04 & Mon 1/31,05 & Planned & & & & & & & \\
\hline 20 & 6B.3.2 PMHT Studies\&Mic & Wed $9 / 29,04$ & Fri $12 / 31 / 04$ & Planned & & & & & $=$ & & \\
\hline
\end{tabular}




\section{Task 7 \\ Coatings \\ (Alstom)}

The major objectives for Task 7 Coatings are:

- Review state-of-the-art of coating technology and identify development needs.

- Develop coating manufacturing techniques, which can provide corrosion/erosion protection for components in USC boilers, cost effectively.

- Establish manufacturing techniques for application of internal coatings for oxidation protection, cost effectively.

- Provide coated samples for corrosion and oxidation testing in the laboratory and "in the field".

These objectives will be accomplished through execution of eight sub-tasks. Where activity on these sub-tasks occurred during the reporting period, it is described below.

\section{Task 7E: Process Scaleup}

\section{Objective}

Perform coating process trials at an intermediate scale between laboratory and commercial size.

\section{Progress for the Quarter}

\section{Part 1: B\&W Effort}

- Praxair was released to develop laser cladding parameters for depositing a $50 \mathrm{Cr} / 50 \mathrm{Ni}$ coating on Haynes 230 tubing. Early in this development, Praxair laser deposited a $50 \mathrm{Cr} / 50 \mathrm{Ni}$ clad build-up, which has since been sectioned and machined into coupons for lab tests on-going at Foster Wheeler. Praxair has not completed their tube cladding task to date. When it is completed, this 2 inch diameter sample will be held for corrosion probe testing, also by Foster Wheeler.

- ASB has reported good success in their efforts to develop plasma transferred arc (PTA) process parameters for depositing $50 \mathrm{Cr} / 50 \mathrm{Ni}$ on Haynes 230 tubing. To date, they have demonstrated success at depositing this cladding material on carbon steel. 


\section{Part 2: Alstom Effort}

The Si-Cr scale-up tests were completed during this quarter. Two sets of tests were conducted using alloy S304 $\mathrm{H}$ and alloy T-92, respectively. Additionally, the $\mathrm{Si}-\mathrm{Cr}$ formulation was utilized to coat sections of T-23, T-91 and alloy HR3C.

In general terms, the diffusion layers formed in alloys T-92 and S304H were about $40 \%$ thicker than those obtained using straight chromizing with no appreciable changes in the average $\mathrm{Cr}$-contents. The Si-level remained above $1 \mathrm{wt} \%$ and $2 \mathrm{wt} \%$ through out the layers formed in the ferritic and austenitic alloys, respectively.

Significant savings can be realized when tubular components could be coated and then formed into reheater and superheater sections. A series of bending tests was conducted using coated components including chromized, Si-Cr and Al-Cr pieces. None of the coated samples could be bent in the as coated condition. However, a tempering at $1400 \mathrm{~F}$ for 30 min allowed for the bending of the chromized T-92 and T-23 pieces with no significant damage to either the OD or ID layers. A solution annealing at $2000 \mathrm{~F}$ for 15 made possible the bending of chromized $\mathrm{S} 304 \mathrm{H}$. Samples coated with the $\mathrm{Al}-\mathrm{Cr}$ diffusion layer could not be bent without compromising the integrity of the coating. The layers generated using the $\mathrm{Si}-\mathrm{Cr}$ formulation may need to be hot bent.

The final scale-up tests are scheduled for the month of April. Final reports summarizing the results of tasks $7 \mathrm{E}$ and $7 \mathrm{D}$ will be issued during the course of the month of May.

\section{Si-Cr Diffusion layers on Ferritic Substrates}

Due to the ID size of the tubing component envisioned for the Ultra-Super-Critical boiler design, the formulations used in the ID varied slightly from that use to coat the OD of the tubing pieces. Every test using the alloy T-92 required ten 5-ft long sections with attached thermocouples to evaluate the effect of temperature. Table 1 lists the pack powder compositions. Sections of alloys T-23 and T-91 were included in the retort tests to evaluate the flexibility of the process. This type of diffusion layer may find an application in re-heater and super-heater sections where coal ash corrosion could be a potential concern. A Si-content greater that $1 \mathrm{wt} \%$ is suggested by the open literature as a minimum requirement for protection against coal-ash corrosion. The optimum concentration is apparently $1.8 \mathrm{wt} \% \mathrm{Si}$.

\begin{tabular}{|l|l|l|}
\hline Process & OD & ID \\
\hline Si-Cr rich layers & $2 \mathrm{wt} \% \mathrm{Si}$ & $3 \mathrm{wt} \% \mathrm{Si}$ \\
& $25 \mathrm{wt} \% \mathrm{Cr}$ & $30 \mathrm{wt} \% \mathrm{Cr}$ \\
& $1 \mathrm{wt} \% \mathrm{NH} 4 \mathrm{Cl}$ & $1 \mathrm{wt} \% \mathrm{NH} 4 \mathrm{Cl}$ \\
& $1 \mathrm{wt} \% \mathrm{CaF} 2$ & $1 \mathrm{wt} \% \mathrm{CaF} 2$ \\
& Bal. Calcined Alumina & Bal. Calcined Alumina \\
\hline
\end{tabular}

Table 1: Compositions of the pack powder used to coat the ID and OD of the ferritic components. 


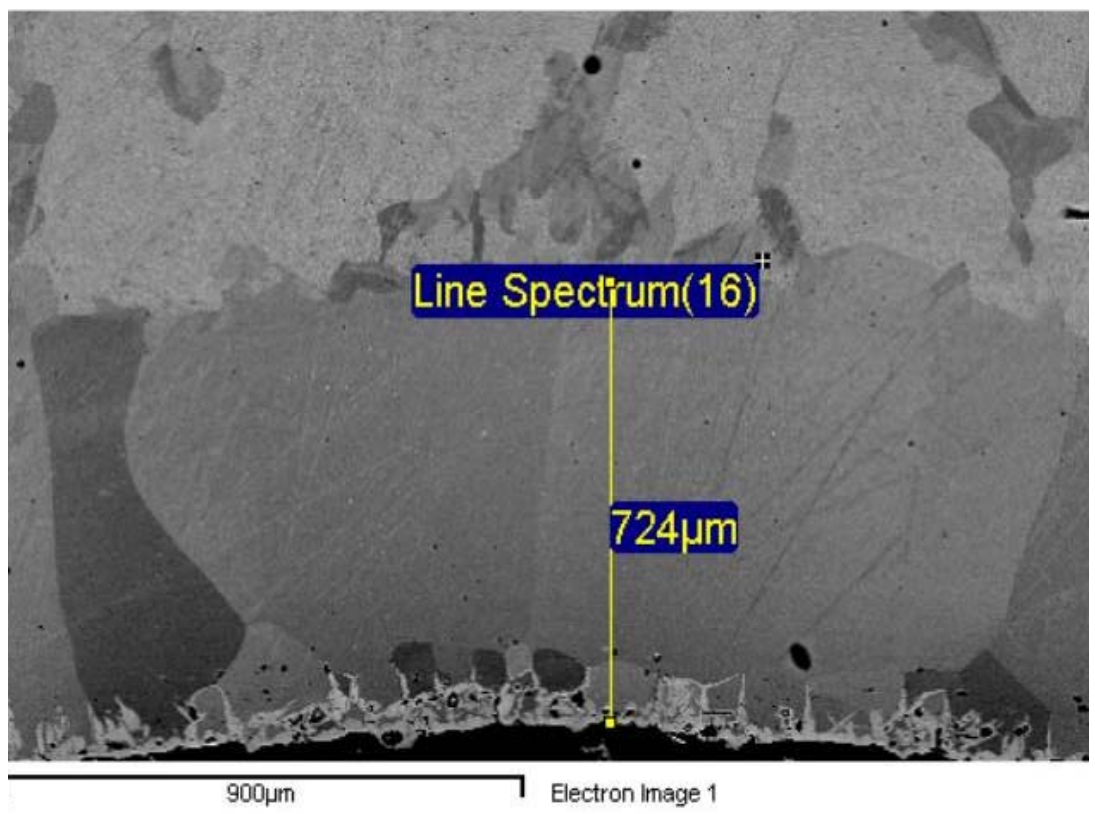

Figure 1: Si-Cr diffusion layer in alloy T-92 at 2060F with hold time of $16 \mathrm{~h}$.

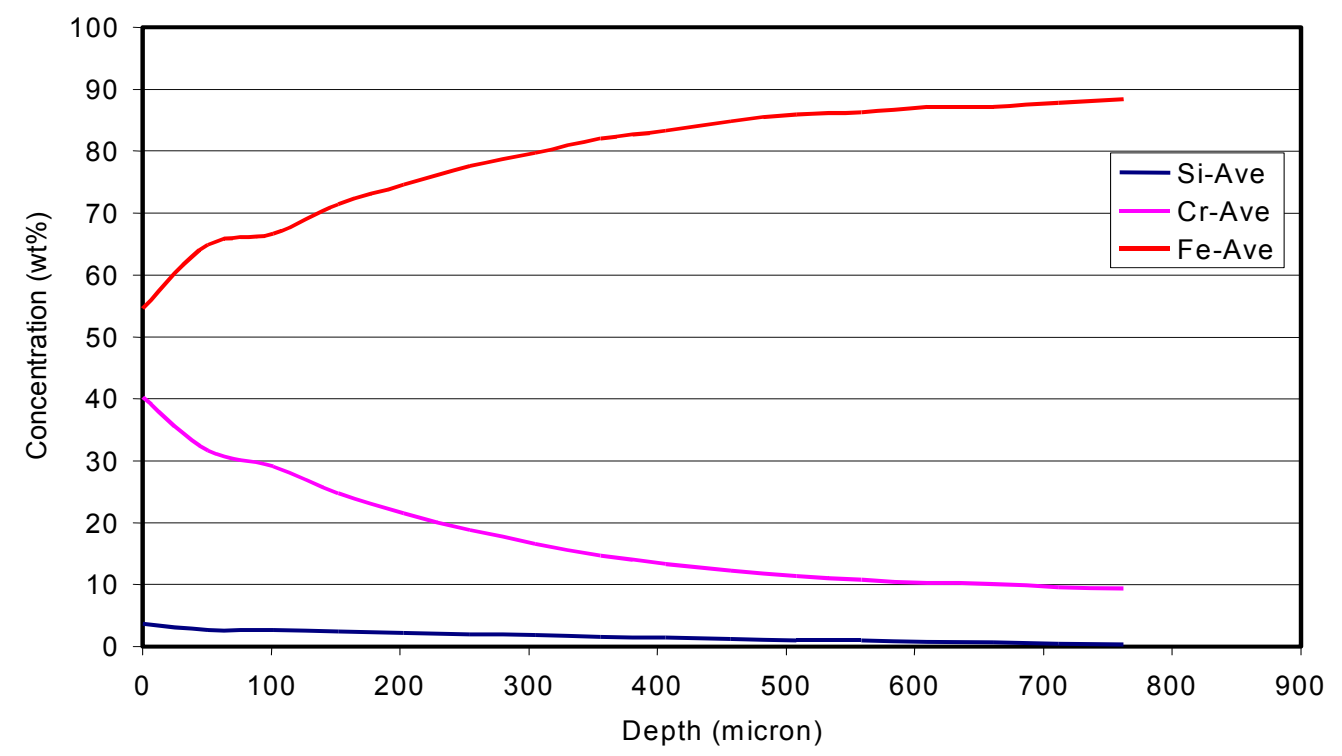

Figure 2: Average composition profiles in the Si-Cr diffusion layer

Figure 1 shows the diffusion layer formed in the samples of alloy T-92. The average composition profiles for the ID layer are depicted in Figure 2 for a process temperature of $2060 \mathrm{~F}$. Similar to the results of the chromizing tests, for alloy T-92 the optimum temperature was $2060 \mathrm{~F}$ or higher without exceeding the temperature limit of $2100 \mathrm{~F}$. Temperatures in excess of $2100 \mathrm{~F}$ for considerable periods of time can result in uneven coating thickness and undesirable intergranular porosity. 
The coated layer was free of carbides at the grain boundaries and the outer surface was composed of a fine-grained $\mathrm{Cr}$-nitride layer. In the as-coated condition this layer had an average hardness of $90 \mathrm{RB}$ similar to that of a chromized layer. The base metal was hardened with an average micro hardness of $35 \mathrm{RC}$.

Alloys T-23 and T-91 were also coated using this formulation. Figure 3 compares the average Si-concentration profiles in the diffusion layers. The average Si-content was apparently higher for the T-23 alloy through the thickness of the coated layer but remained above $1 \mathrm{wt} \%$ for all ferritic alloys at the coating/base metal interface.

During the coating process the temperature distribution is continually monitored using thermocouples attached to the test pieces. The sections used for the metallographic

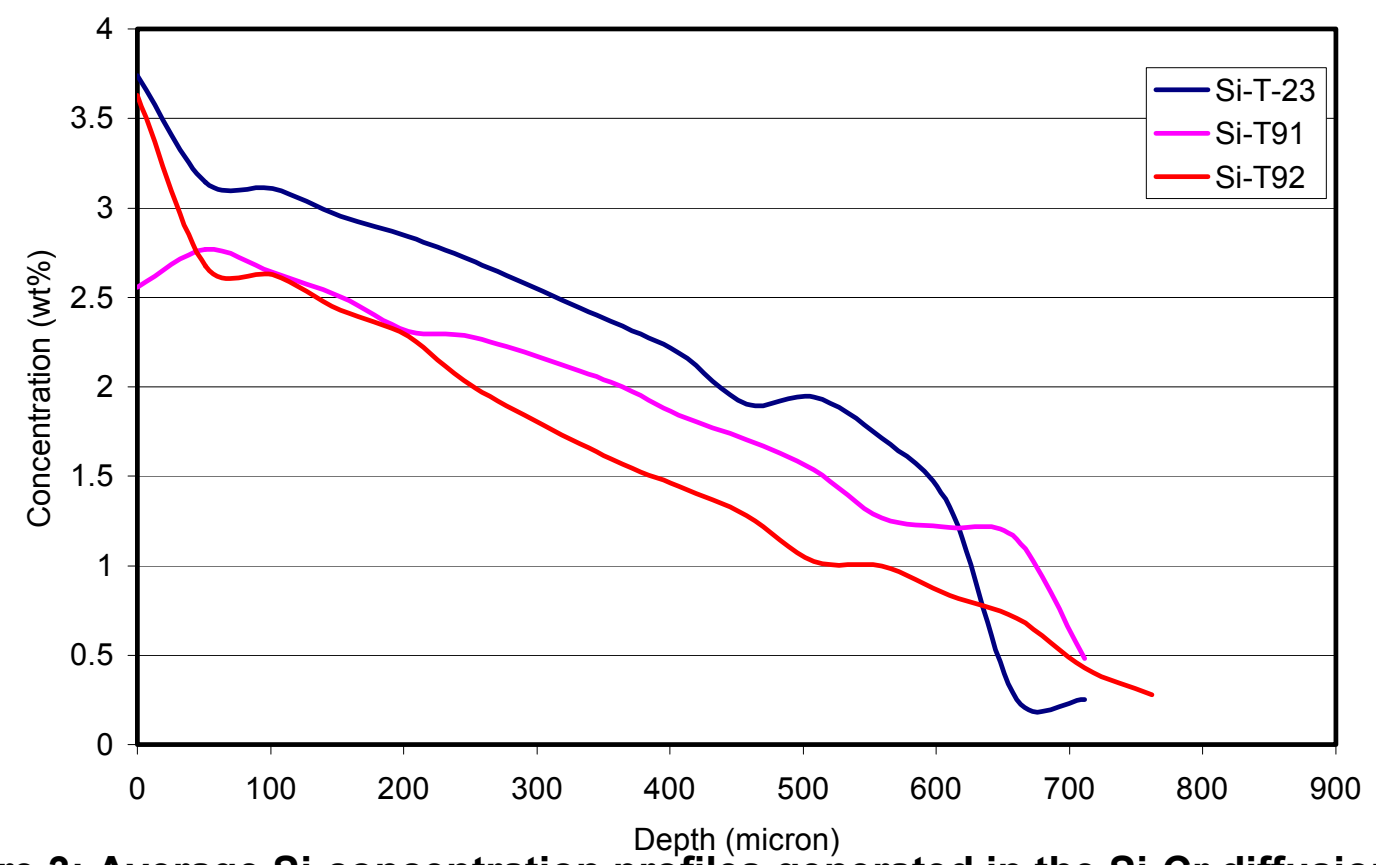

Figure 3: Average Si-concentration profiles generated in the Si-Cr diffusion layers using the alloys T-23, T-91, and T-92

evaluation are taken adjacent to the location of the monitoring thermocouples. In this fashion the characteristics of the coated layers in terms of thickness and composition can be correlated to temperature and process time. Due to the insulating character of the calcined alumina and the heating characteristics of the furnace, during the heat up process higher temperatures will be recorded toward the walls of the retort. During the first set of tests in this task it was agreed to heat up in stages to bring the pack to temperature in a more homogeneous fashion. However, the components located toward the walls of the retort reach temperature at about 6 to $8 \mathrm{~h}$ earlier than soaking time. The minimum initiation temperature of each test has been set at $2040 \mathrm{~F}$. Therefore, there is a hidden effect of time on the overall temperature to thickness correlation. Figure 4 shows the temperature-thickness correlation for alloy T-92. The Correlation of the data suggests a linear relation between coating thickness and temperature. 


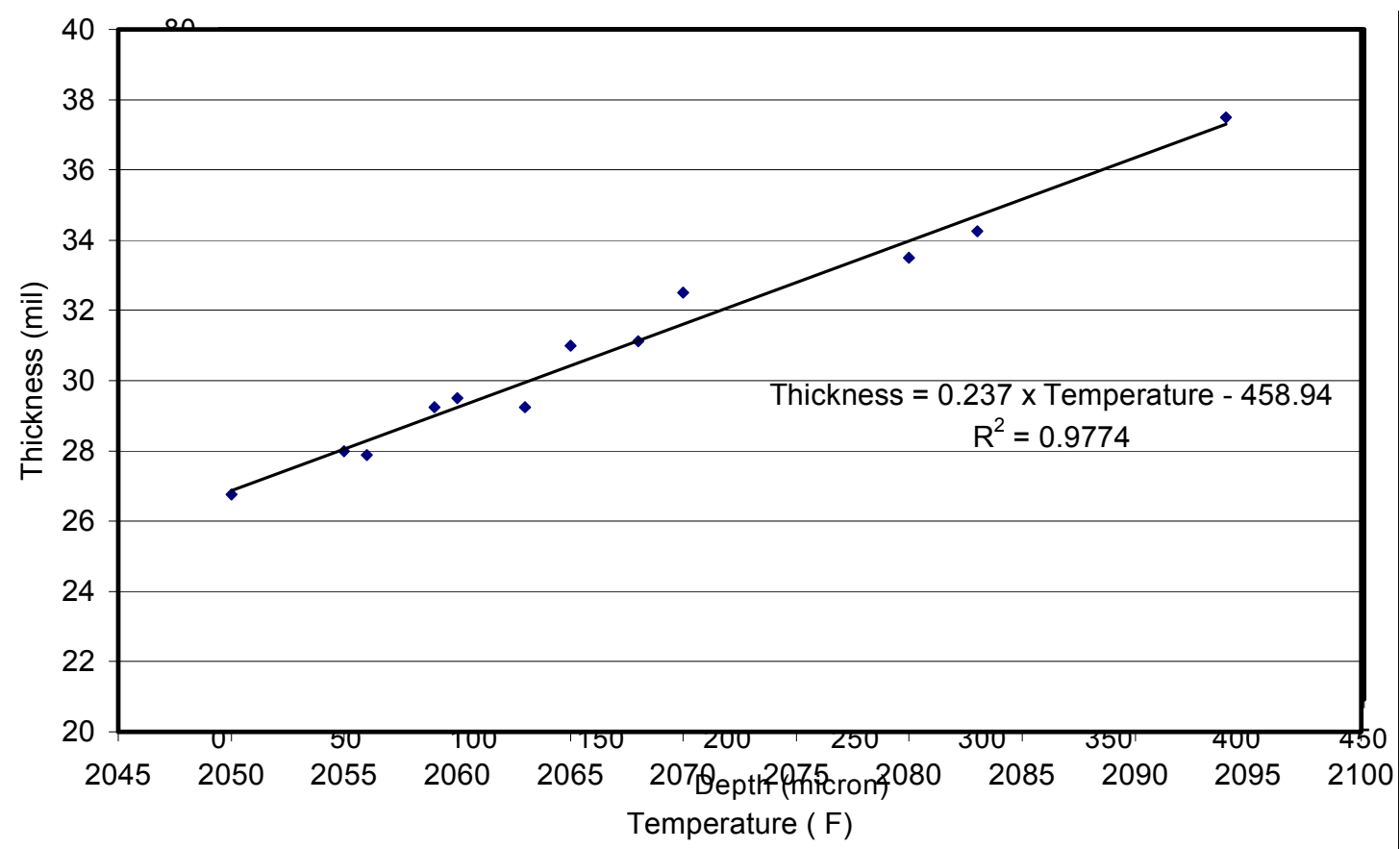

Figure 4: Thickness as a function of temperature for the $\mathrm{Si}-\mathrm{Cr}$ diffusion layer formed in T-92

Si-Cr Diffusion Layers on Austenitic Substrates

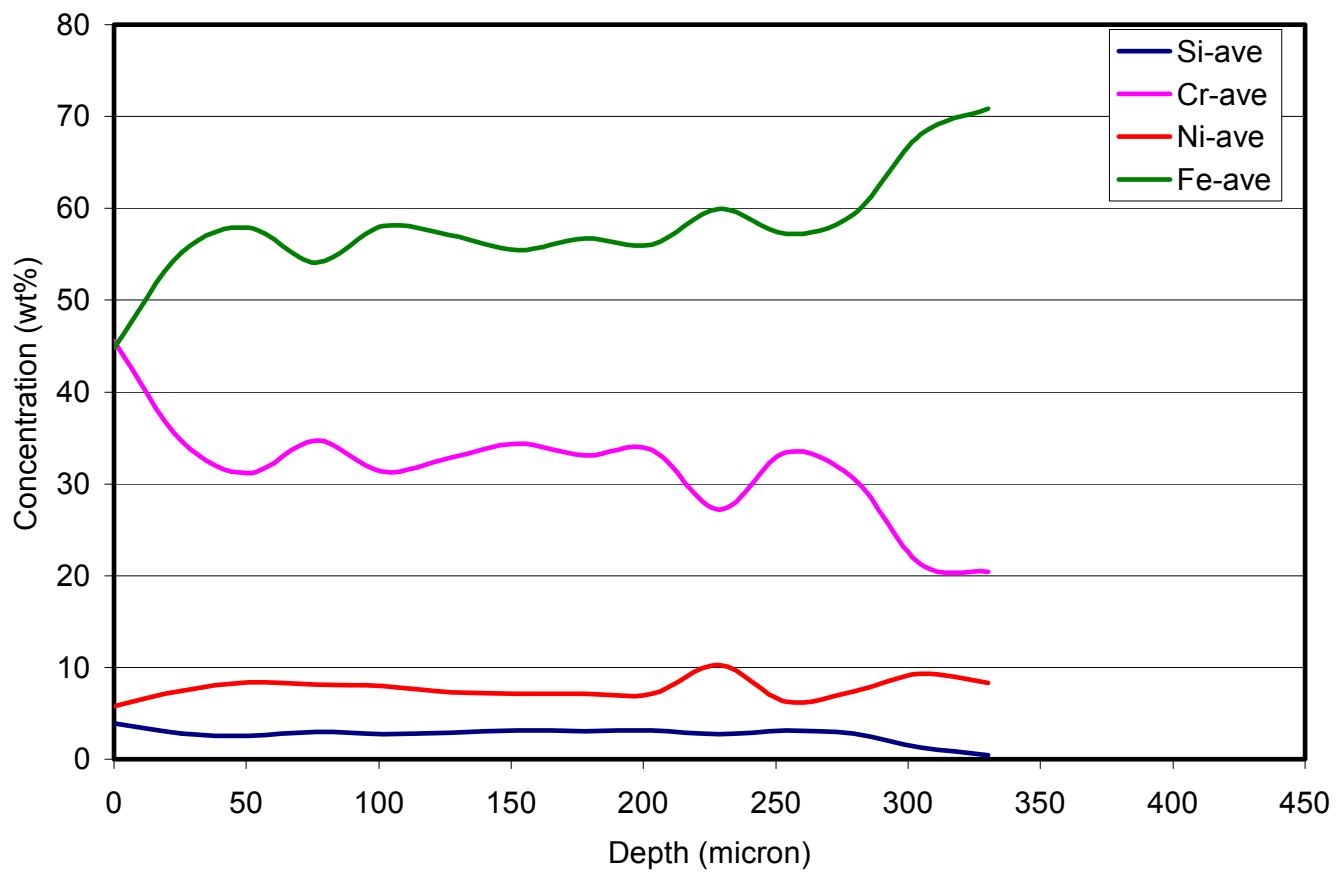

Figure 5: Composition profiles for the ID layer formed in Super 304H at 2054F. 
The austenitic alloys were coated using the same formulation in the ID and OD. The pack contained $2 \mathrm{wt} \% \mathrm{Si}$ and $25 \mathrm{wt} \% \mathrm{Cr}$. The activators $\mathrm{NH} 4 \mathrm{Cl}$ and $\mathrm{CaF} 2$ were present in a 1:1 ratio. Figure 5 shows the average concentration profile for the layer formed in alloy $\mathrm{S} 304 \mathrm{H}$ at $2054 \mathrm{~F}$.

The concentration profile differs from that obtained in ferritic type of alloys in that there is no gradient. The content of each element present in the layer remains within a narrow concentration within the diffusion layer. A solution annealing at $2000 \mathrm{~F}$ for $15 \mathrm{~min}$ homogenizes the profiles and the composition of the diffused layer resembles that of a monolithic alloy.

Figure 6 depicts the structure of the ID layer formed at $2054 \mathrm{~F}$. The white precipitates are $\mathrm{Nb}-\mathrm{Cr}$-Si intermetallic precipitates. The hardness of this layer in as-coated condition averages $60 \mathrm{RC}$. The underlying base metal is unaffected by the coating process since

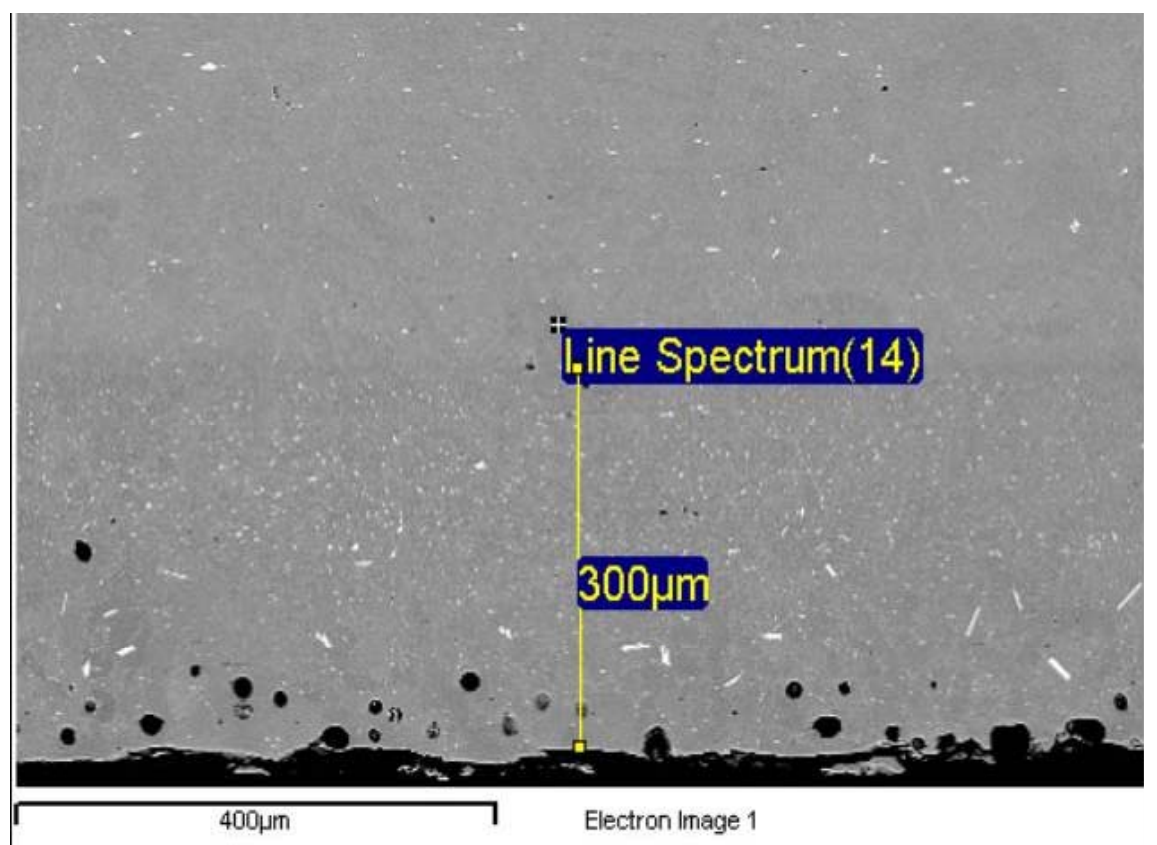

Figure 6: Si-Cr diffusion layer formed in alloy S304H at $2054 \mathrm{~F}$ for $16 \mathrm{~h}$.

the growth of the layer takes place within the solution annealing temperature range. The hardness of this coating is comparable to that of the chromized layers in $\mathrm{S} 304 \mathrm{H}$ alloy. After solution annealing the hardness value drops to around $35 \mathrm{RC}$. The sample can be bent with no detriment to the ID layer. However, in two out of 4 samples there were a few discrete cracks generated in the OD layer. Hot bending is proposed for this product.

Figure 7 shows the $\mathrm{Si}-\mathrm{Cr}$ concentration profiles in the diffusion layer formed in the HR3C material. The Si and $\mathrm{Cr}$ average concentration through the coating thickness remain at 2 and $50 \mathrm{wt} \%$, respectively. The thickness is half that obtained with alloy $\mathrm{S} 304 \mathrm{H}$. 


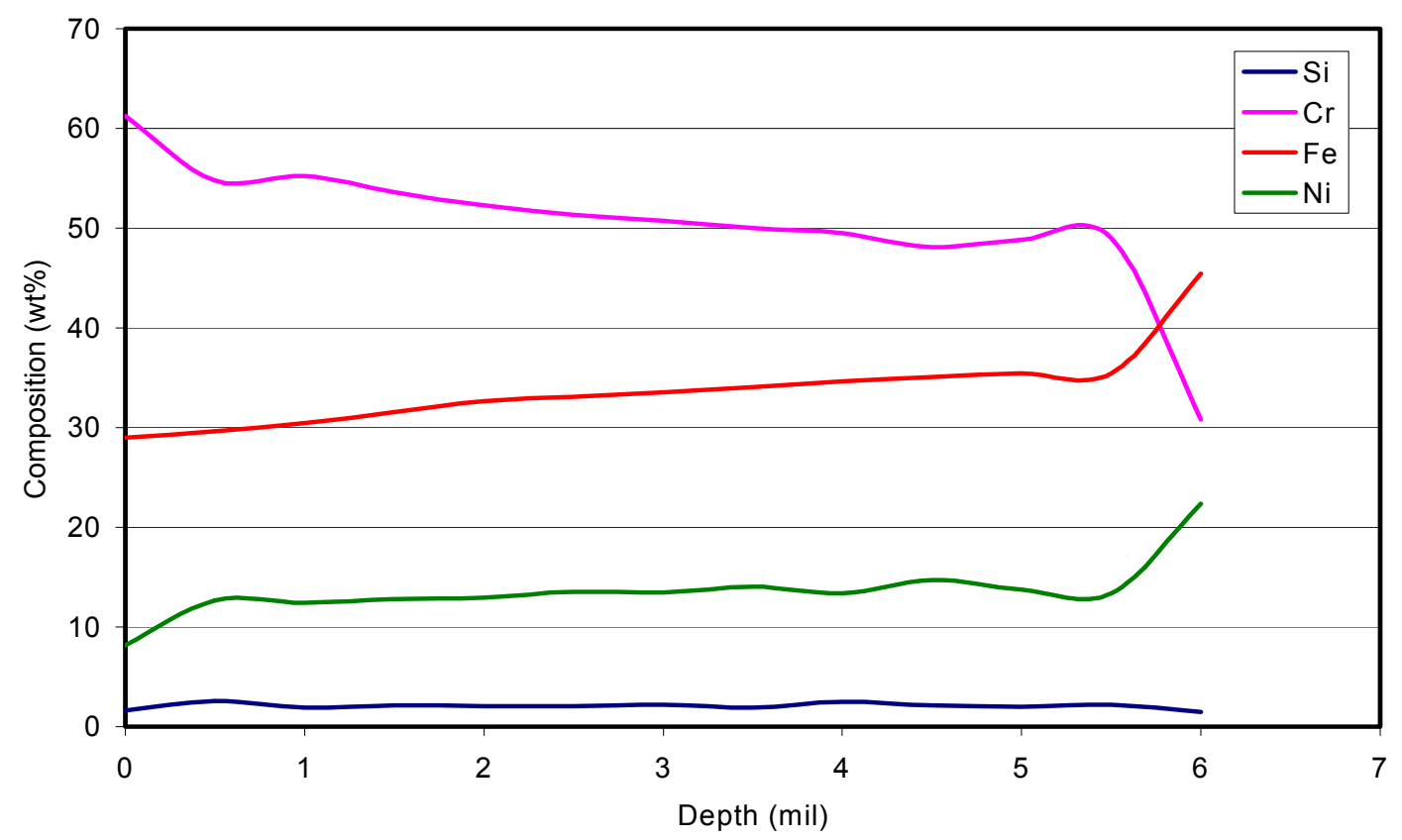

Figure 7: Composition profiles in the Si-Cr diffusion layer in HR3C

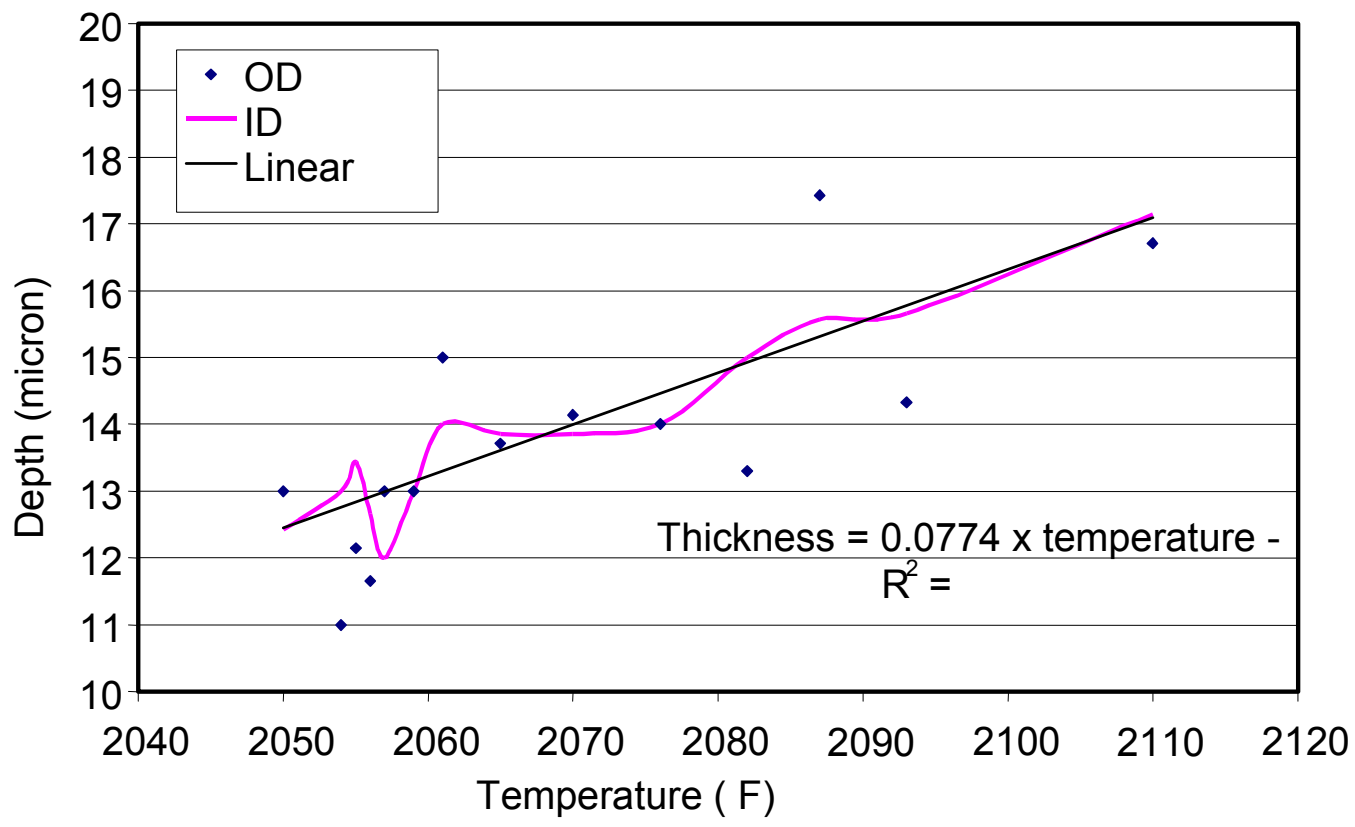

Figure 8: Thickness variation as a function of temperature fro loads 7 and 9. SiCr coating in $\mathrm{S} 304 \mathrm{H}$. 
A correlation between coating thickness and temperature was also derived from the experimental data, Figure 8. As for the ferritic alloys the time effect is hidden.

\section{Conclusions}

- The feasibility of the Si-Cr diffusion coatings has been demonstrated in an intermediate commercial facility.

- The coating temperature for the ferritic alloys should be maintain at or above $2060 \mathrm{~F}$ during the soaking time to achieve the desired Si-concentration profile.

- The austenitic alloys require a minimum process temperature of 2050F.

- The process temperature should not exceed $2100 \mathrm{~F}$ for considerable periods of time.

- A solution annealing at $2000 \mathrm{~F}$ for $15 \mathrm{~min}$ for the coated austenitic alloys homogenizes the coating chemistry.

\section{Recommendations}

- Hot bending is proposed for the Si-Cr coated samples to avoid cracking of the OD layers.

- Tumbling, wire brushing and/or sand blasting is recommended to improve the appearance of the Si-Cr layers. These layers tend to be rough due to the formation of a thin and hard outward growing $\mathrm{Cr}-\mathrm{N}$ layer.

\section{Concerns}

B\&W has indicated that fiscal year funding for this task have been committed. Without release of additional funding, task work will be halted.

\section{Activities Planned for Next Quarter}

B\&W contracted work at Praxair and ASB will be brought to completion, then, this task will remain on-hold until additional funding is released.

\section{Task 7H: Specimens for Field Corrosion/Oxidation}

\section{Objective}

Provide externally and internally coated specimens for inclusion in corrosion/oxidation testing under Tasks 3 and 4.

\section{Progress for the Quarter}

Samples of Super 304H tubing were included in scale-up diffusion coating runs for future use in the Task 4 air-cooled field probe testing. 


\section{Concerns}

B\&W supplied externally clad test samples may not be available for Task 4 air-cooled field probe testing.

\section{Plans for the Next Quarter}

Continue production of diffusion-coated tubing samples for Task 4 . 
USC Materials -

\begin{tabular}{|c|c|c|c|c|c|c|c|}
\hline \multirow[t]{2}{*}{ Task Name } & \multirow[t]{2}{*}{ Status } & 2002 & 2003 & \multicolumn{2}{|c|}{2004} & 2005 & 2006 \\
\hline & & \begin{tabular}{|l|l|l|l|} 
Gtr 1 & Gtr 2 & Gtr 3 & Gtr 4 \\
\end{tabular} & \begin{tabular}{|l|l|l|l|} 
Gtr 1 & Gtr 2 & Gtr 3 & Gtr 4 \\
\end{tabular} & \begin{tabular}{|l|l|l|l|l|} 
Gotr 1 & Gatr 2 \\
\end{tabular} & \begin{tabular}{|l|l|} 
Getr 3 & Gtr 4 \\
\end{tabular} & \begin{tabular}{|l|l|l|l|} 
Gtr 1 & Gtr 2 & Gtr 3 & Gtr 4 \\
\end{tabular} & \begin{tabular}{|l|l|l|l|} 
Gtr 1 & Gtr 2 & Gtr 3 & Gtr 4 \\
\end{tabular} \\
\hline \multicolumn{8}{|c|}{ 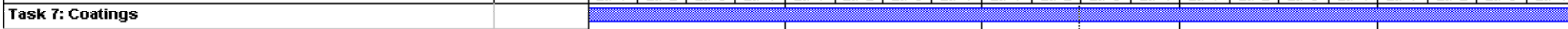 } \\
\hline \multicolumn{8}{|l|}{ Task 7A: Detailed Study of Current State of the Art } \\
\hline Alstom Task 7A: Detailed Study of Current State of the Art & Complete & & & & & & \\
\hline \multicolumn{8}{|l|}{ Task 7B: Coating Feasibility (Internal Coating) } \\
\hline Alstom Task 78: Coating Feasibility (Internal Coating) & $95 \%$ & & & & & & \\
\hline \multicolumn{8}{|l|}{ Task 7C: Coating Recommendations } \\
\hline Alstom Task 7C: Coating Recommendations & $20 \%$ & & & & & & \\
\hline \multicolumn{8}{|l|}{ Task 7D: Laboratory Testing } \\
\hline Alstom Task 7D: Laboratory Testing & $50 \%$ & & & & & & \\
\hline \multicolumn{8}{|l|}{ Task 7E: Process Scale Up - Preliminary Trials } \\
\hline Alstom Task 7E: Process Scale Up - Preliminary Trials & $80 \%$ & & & & & & \\
\hline B\&W Task 7E: Process Scale Up - Preliminary Trials & $40 \%$ & & & ox & & & \\
\hline \multicolumn{8}{|l|}{ Task 7F: Process Optimization } \\
\hline \multicolumn{8}{|l|}{ Alstom Task 7F: Process Optimization } \\
\hline \multicolumn{8}{|l|}{ B\&W Task 7F: Process Optimization } \\
\hline \multicolumn{8}{|l|}{ Task 7G: Manufacturing Recommendations } \\
\hline \multicolumn{8}{|l|}{ Alstom Task 7G: Manufacturing Recommendations } \\
\hline \multicolumn{8}{|l|}{ B\&W Task 7G: Manufacturing Recommendations } \\
\hline \multicolumn{8}{|l|}{ Task 7H: Specimens for Field Corrosion/Oxidation } \\
\hline Alstom Task 7H: Specimens for Field Corrosionioxidation & $55 \%$ & & & & & & \\
\hline B\&W Task 7H: Specimens for Field Corrosion/Oxidation & $55 \%$ & & & & & & \\
\hline \multicolumn{8}{|l|}{ Task 71: Project Management } \\
\hline Alstom Task 7l: Project Management & Ongoing & & & & & & \\
\hline B\&W Task 7l: Project Management & Ongoing & & & & & & \\
\hline
\end{tabular}




\section{Scope Accomplished Versus Actual Expenditures}

Task 7 Coatings Alstom Scope

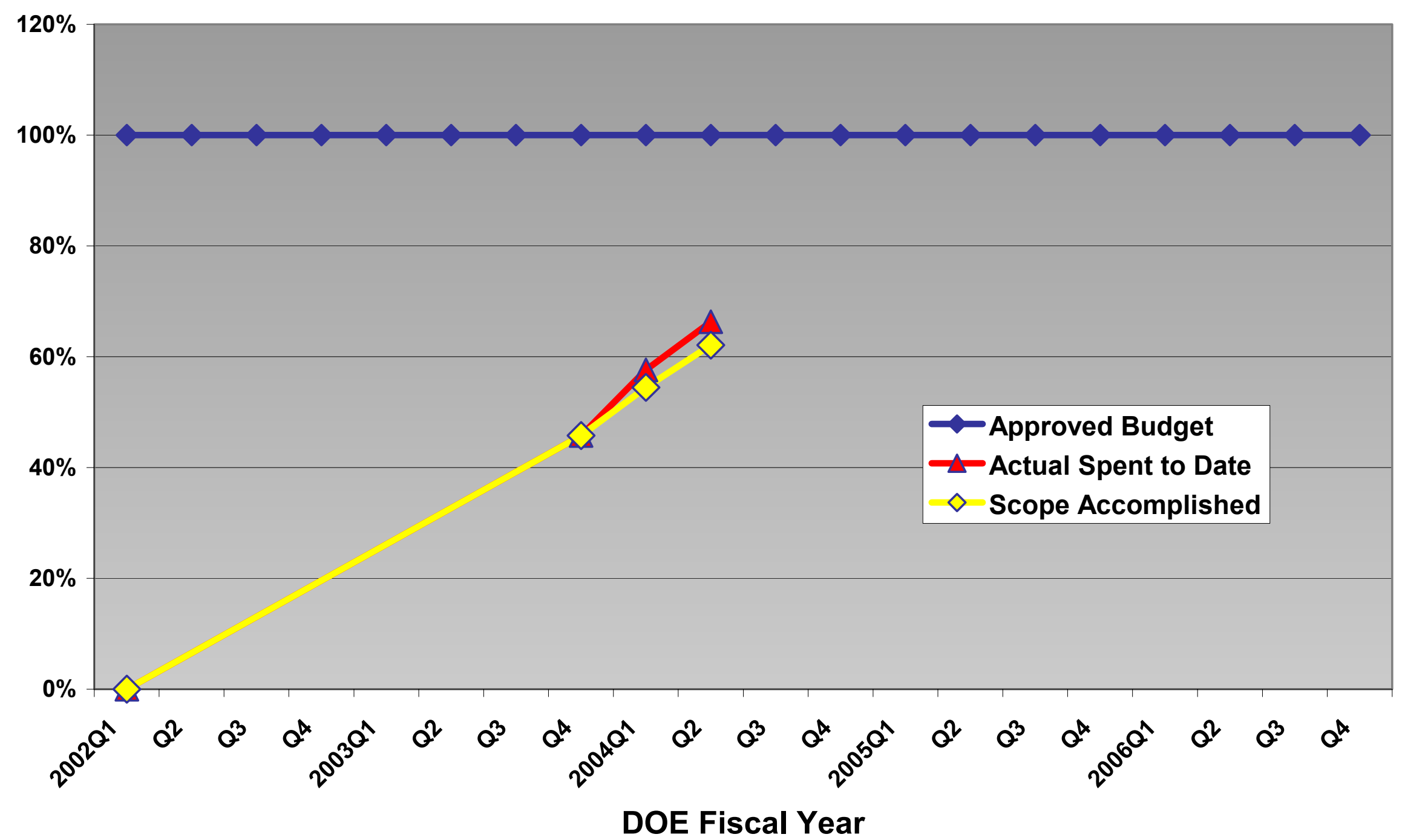




\section{Task 8 \\ Design Methods and Data \\ (Alstom)}

The major objectives for Task 8 are:

- Review the methods used by Section I of the ASME Boiler and Pressure Vessel Code to utilize materials properties and behavior models in the design of ultrasupercritical boilers.

- Develop and document methodologies whereby the results of the other tasks within this program may be most effectively applied within the ASME Section I design environment.

- Pursue the incorporation of such methodologies into Section I.

These objectives will be accomplished through execution of seven sub-tasks. Where activity on these sub-tasks occurred during the reporting period, it is described below.

\section{Task 8A: Task Management (ALSTOM)}

\section{Objective}

The primary objective of this subtask is the overall management of the task, coordinating meetings and preparing progress reports.

\section{Progress for the Quarter}

- Work continues to confirm commitments from each participant.

- The Gantt chart for Task 8, showing the overall plan and progress to date is included at the end of this report.

\section{Concerns}

Continued effort is ongoing to confirm commitments of each participant, update the project plan and develop curves to report scope completed as a function of spend.

\section{Plans for the Next Quarter}

Continue general task management activities. 


\section{Task 8B: Material Data Collation and Processing (FW)}

\section{Objective}

The creation of documentation to ensure that quality test data is transferred between tasks and that this data remains traceable. A second objective is the analysis of such data with the objective of improving the statistical correlation. Foster Wheeler is subtask leader, with Riley Power Inc. providing significant input to this subtask.

\section{Deliverables}

\begin{tabular}{|l|l|l|}
\hline \multicolumn{1}{|c|}{ Item } & Responsible & \multicolumn{1}{c|}{ Status } \\
\hline Material data transfer sheets & ALSTOM & $\begin{array}{l}\text { Transfer sheets provided for } \\
\text { creep and tensile tests. }\end{array}$ \\
\hline Electronic data repository & ORNL & Website nearly complete. \\
\hline Recommendations for statistical analysis of data & & \\
\hline Data compendia and fits for key materials & & \\
\hline $\begin{array}{l}\text { Code case packages and submissions to code } \\
\text { committees }\end{array}$ & ALL & \\
\hline
\end{tabular}

\section{Progress for the Quarter}

Oak Ridge has made considerable progress in getting the website designed for dissemination of Task 2 materials test data.

\section{Concerns}

None

\section{Plans for the Next Quarter}

Ensure that ORNL works to make test data available in electronic format. Begin developing methods and tools for statistical analysis of material data.

\section{Task 8E: Continuum Damage Mechanics (B\&W)}

\section{Objective}

The objective of this subtask is to analyze uniaxial and multiaxial creep test data from Task 2 for several (three) materials to:

- establish the continuum damage mechanics (CDM) parameters,

- evaluate multi-axial strength theories and failure criteria,

- assess the implications of cyclic creep for USC materials, 
- evaluate and compare CDM, reference stress and Omega models of typical ASME geometries.

\section{Concerns}

Timely availability of material data in electronic format.

\section{Plans for the Next Quarter}

Review of literature and benchmarking of procedures will continue. Work will start on the Cyclic Creep subtask by evaluating a flawed header component made of P91 material.

\section{Task 8F: Weld Analysis and Assessment (ALSTOM)}

\section{Objective}

Create simplified analysis models of welds and heat affected zones (HAZ) utilizing material properties obtained from the open literature and from Task 2 to permit accurate creep life assessment of weldments.

\section{Deliverables}

\begin{tabular}{|l|l|l|}
\hline \multicolumn{1}{|c|}{ Item } & Responsible & \multicolumn{1}{c|}{ Status } \\
\hline $\begin{array}{l}\text { Topical review of weld analysis and assessment } \\
\text { in creep range. }\end{array}$ & ALSTOM \& RPI & In progress. \\
\hline Collation of material data for weld metal and HAZ. & RPI & \\
\hline Creep models for weld metal and HAZ regions. & ALSTOM & \\
\hline $\begin{array}{l}\text { Report documenting the simulation of welded } \\
\text { specimens and common Code geometries. }\end{array}$ & ALSTOM & \\
\hline $\begin{array}{l}\text { Report documenting the development and use of } \\
\text { approximate weld assessment methods. }\end{array}$ & ALL & \\
\hline
\end{tabular}

\section{Progress for the Quarter}

A literature review was started and some relevant papers obtained. A copy of the proceedings was obtained for a recent conference (November 2003) entitled "Integrity of High Temperature Welds". Riley Power Inc. has volunteered to assist in the literature review and development of analytical methods for weld assessment.

\section{Concerns}

This subtask has fallen behind schedule but the prognosis for the next quarter is encouraging now that work scope issues are largely resolved. 


\section{Progress for the Next Quarter}

Finish literature review and issue a report to summarize issues and methods for weld assessment. Work will begin to collate mechanical property data for weld metal and HAZ regions.

\section{Task 8G: Basic Design Rules for Cylinders (ALSTOM)}

\section{Objective}

Review the various equations used by the ASME Code, Section I for Power Boilers to define the minimum thickness of cylinders under internal pressure and develop a single methodology applicable to ultrasupercritical boilers.

\section{Deliverables}

\begin{tabular}{|l|l|l|}
\hline \multicolumn{1}{|c|}{ Item } & Responsible & \multicolumn{1}{c|}{ Status } \\
\hline $\begin{array}{l}\text { Report summarizing existing approaches and } \\
\text { comparing and contrasting their predictions }\end{array}$ & ALSTOM & Complete (Aug 2003) \\
\hline $\begin{array}{l}\text { Report recommending a single equation with } \\
\text { supporting theoretical data. }\end{array}$ & ALSTOM & Complete (Sept 2003) \\
\hline Code case submission & ALSTOM & Complete (October 2003) \\
\hline
\end{tabular}

\section{Progress for the Quarter}

Preparations were made for presentations to ASME next quarter.

\section{Concerns}

None.

\section{Plans for the Next Quarter}

Make presentations in May to ASME Section 1 and B31.1. 
Appendix A: Project Plan with Progress Identified

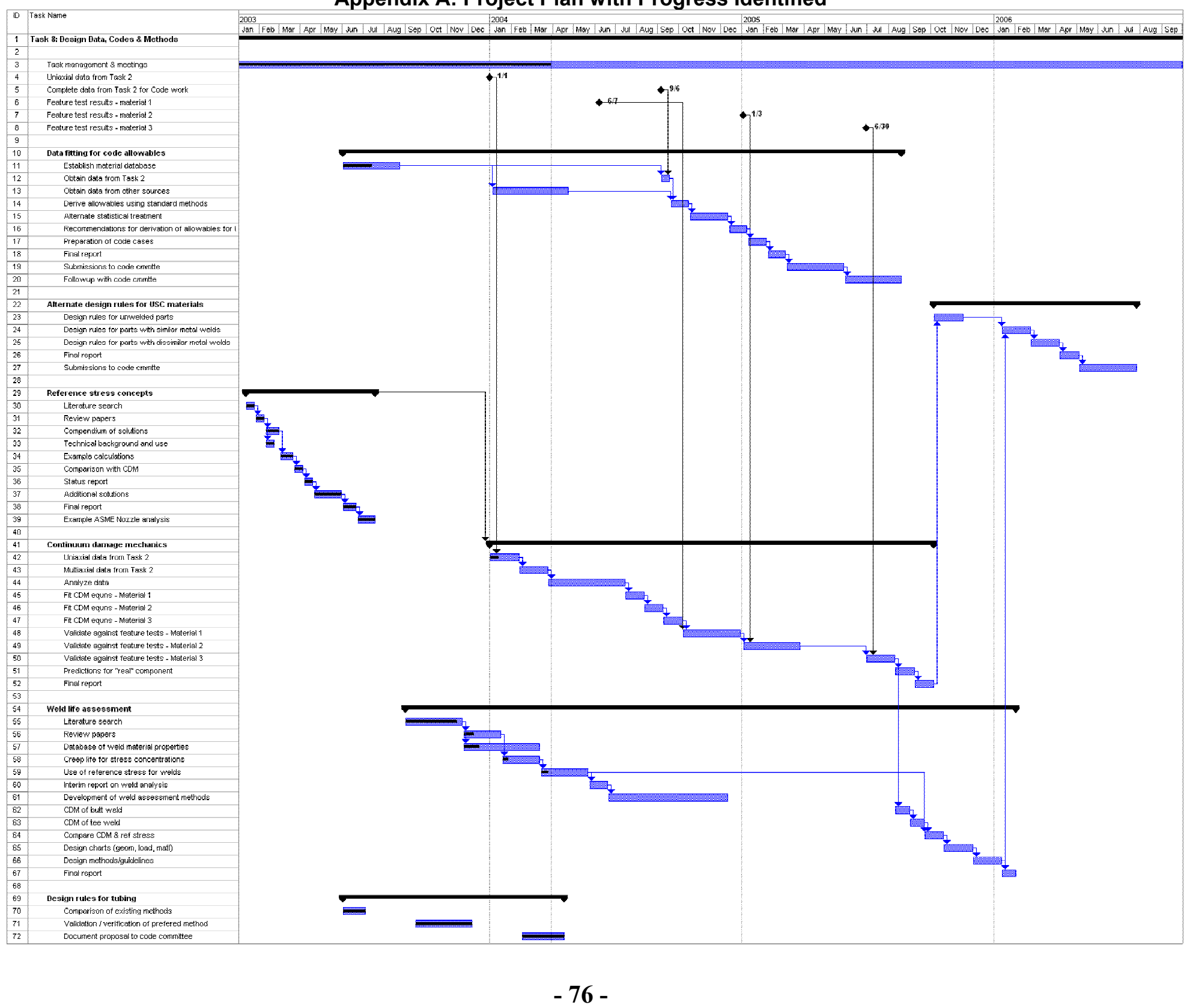




\section{Task 9 \\ Project Integration and Management (EPRI)}

The objective of Task 9 is to coordinate the project and provide reporting to DOE and Ohio Coal Development Office (OCDO).

\section{Progress for the Task}

- Completed Fourth Quarterly Report for 2003

- Completed Monthly Reports for October and November

- Coordinated and provided minutes for Steering Committee Meeting on November 12-13, 2003 in Columbus Ohio.

- Monthly conference calls were held and the discussions were documented.

- Issued a call for papers for the EPRI Fourth International Conference on Advances in Materials Technology for Fossil Power Plants. This conference is being cosponsored by DOE and will include presentations on many of the developments from this project. The conference will be held at the Hilton Oceanfront Resort in Hilton Head Island, South Carolina on October 26-28, 2004.

A final report has been completed and distributed. 